Aurélia Estela Coutinho Carvalho Simplício e Família Carvalho

\title{
CONTOS DA LAGOA 88
}

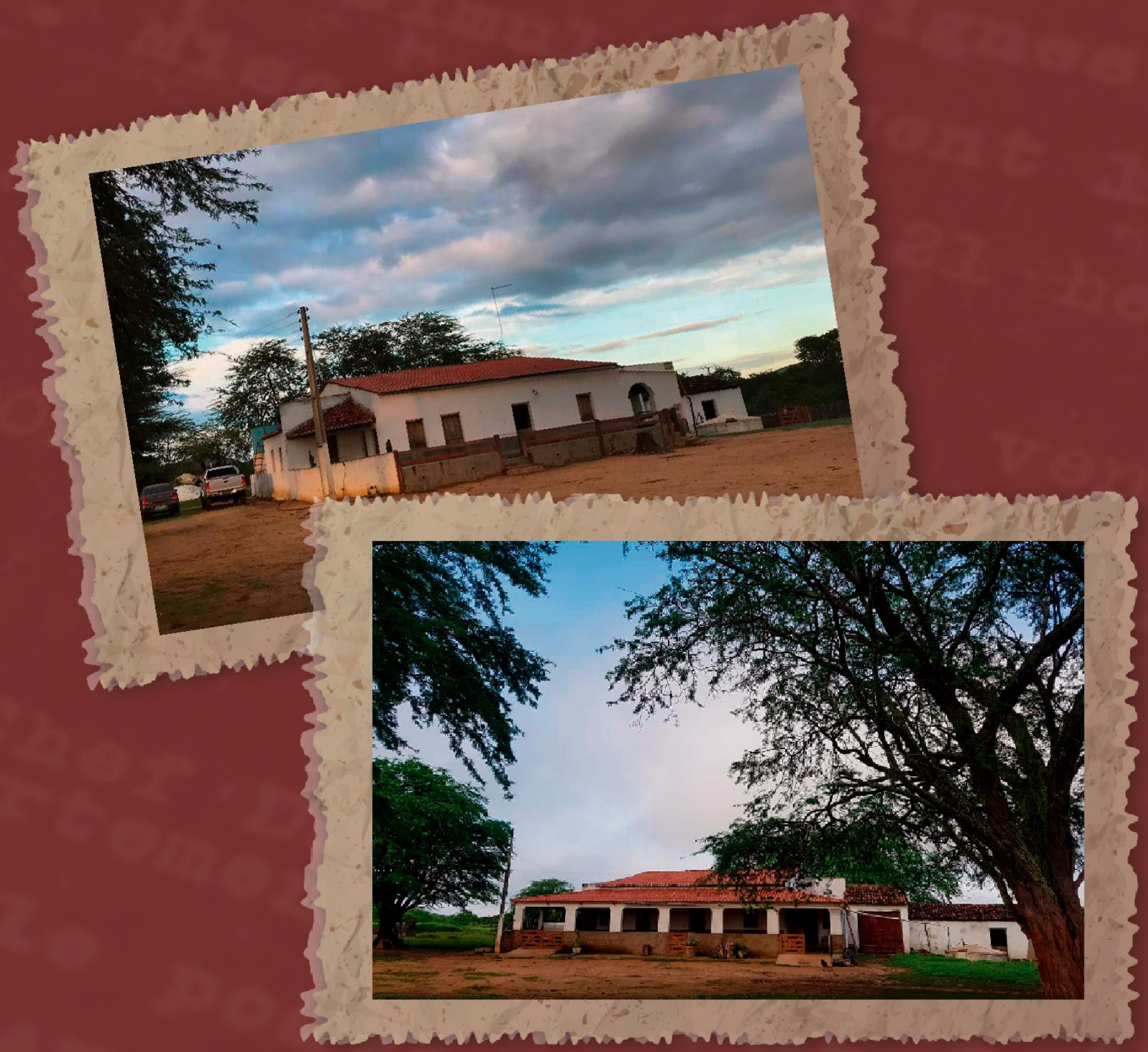

Fortaleza

IMAC

2020

( $\left.\rho_{0} \Leftrightarrow \mathscr{L}\right)$ 
CONTOS DA LAGOA 
Aurélia Estela Coutinho Carvalho Simplício

Família Carvalho (Participação Especial)

\section{CONTOS DA LAGOA}

Fortaleza

Editora

2020 
2020 Aurélia Estela Coutinho Carvalho Simplício

Contos da Lagoa

Disponível também em: www.editoraimac.com.br

Ficha catalográfica

S612c Simplício, Aurélia Estela Coutinho Carvalho.

Contos da lagoa / Aurélia Estela Coutinho Carvalho Simplício - Fortaleza :

IMAC, 2020.

163 p. : il. ; $15 \times 21 \mathrm{~cm}$

Família Carvalho (Participação Especial).

Livro em formatos impresso e eletrônico.

ISBN 978-65-993219-1-7

e-ISBN 978-65-993219-0-0

1. Literatura Brasileira. 2. Contos. I. Título.

CDD: 869.3

Editora IMAC

E-mail: contato@editoraimac.com.br

Site: www.editoraimac.com.br

\section{Produção}

Aurélia Estela Coutinho Carvalho Simplício

\section{Participação Especial}

Família Carvalho

\section{Direção Editorial}

Ivana Cristina Vieira de Lima Maia

Normalização Bibliográfica

Paula Pinheiro da Nóbrega

\section{Revisão dos Textos}

Luana Monteiro

\section{Capa}

Paulo Costa dos Santos 
Dedico esta coletânea de memórias da Fazenda Lagoa das Pedras ao meu pai Manoel Vieira de Carvalho - Capitão Manoelzinho ou apenas Seu Manoelzinho, assim conhecido no sertão do Piauí e Ceará, por ter me ensinado valores morais e cristãos, fundamentais para minha vida cidadã, e à Dona Estrelinha, por ter junto com ele me ensinado a buscar aprender a viver da melhor forma possível, sempre superando as adversidades da vida. 


\section{AGRADECIMENTOS}

A toda Família Carvalho, que atendeu ao meu convite e produziu textos memoráveis, sem os quais o livro Contos da Lagoa não seria, assim, tão rico de memórias.

A Deus, por me conceder a graça de me encorajar para realizar esse sonho, deixando registrada a história exemplar de amor, respeito e cumplicidade desse casal. 


\section{SUMÁRIO}

1 SOBRE OS CONTOS .............................................................................. 10

2 MEUS PAIS ...................................................................................................... 11

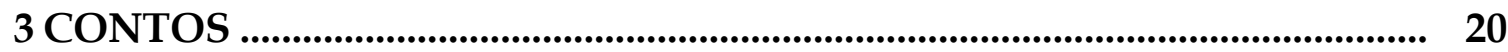

3.1 O encontro inusitado de um grande amor ....................................................... 20

3.2 A casa da fazenda ............................................................................................ 23

3.3 Um dia na fazenda ................................................................................... 27

3.4 Aiá e Bebela ......................................................................................................... 31

3.4.1 Algumas de suas histórias ......................................................................... 32

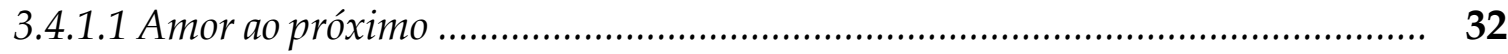

3.4.1.2 Visita ao Padim Padim Ciço ...................................................................... 33

3.5 Meus galos não estão à venda! ........................................................................... 33

3.6 O pavio do rádio ......................................................................................................... 34

3.7 Pescoço de galinha .............................................................................................. 35

3.8 As escapadas da tia Ferreira ............................................................................... 35

3.9 Trapaceando as crianças .................................................................................... 36

3.10 Cavalo ou parede do açude? ............................................................................. 36

3.11 Cacimba d'água .................................................................................................... 37

3.12 Deixando Juiz de Direito sem palavras ............................................................ 37

3.13 Lagoa das Pedras de todos ............................................................................... 39

3.14 Memórias de um fim de férias ......................................................................... 41

3.15 Férias com meus avós ............................................................................................ 44

3.16 Exemplo de solidariedade ................................................................................. 47

3.17 Isso é que é ter compromisso! ......................................................................... 49

3.18 Brincadeiras sertanejas ...................................................................................... 50

3.19 Da Lamparina à Internet .............................................................................. 52

3.20 O valentão das Alagoas .................................................................................... 52

3.21 Carneiro parido com dois cabritinhos! ............................................................ 54

3.22 Galope desastrado ........................................................................................... 54

3.23 Tibelo ....................................................................................................... 54

3.24 “Cibazol de muié" bordar ................................................................................... 55 
3.25 Revólver, só faz medo de longe .................................................................. 55

3.26 Oh! Que negócio desmantelado! ...................................................................... 56

3.27 O especial cachorro Jacuí .................................................................................. 56

3.28 Web.causo.com ................................................................................................. 57

3.29 Lagoa Encantada das Pedras, energia em movimento ................................. 58

3.30 A viagem ............................................................................................................. 59

3.31 A casa .................................................................................................... 61

3.32 Minha rede e as selas de montaria ............................................................... 62

3.33 Lagoa das Pedras: o meu lugar do mundo ........................................................ 65

3.34 A netinha caçula .............................................................................................. 71

3.35 Rancho Mucunã ........................................................................................ 73

3.36 Meus passeios na fazenda ............................................................................... 77

3.37 Travessuras de criança ................................................................................. 81

3.38 Pedido de um filho ................................................................................. 82

3.39 Fazendo arte nas melancias ..................................................................... 82

$3.40 \mathrm{O}$ troco errado ...................................................................................................... 83

3.41 O campeão largado na cancela .......................................................................... 85

3.42 Só um fiozinho desligado .............................................................................. 87

3.43 Os cuidados de minha mãe ............................................................................. 88

3.44 Jogo de baralho ................................................................................................... 88

$3.45 \mathrm{O}$ "cabra" que desafiou um desembargador .................................................. 88

3.46 $\mathrm{O}$ açougue da cidade de Castelo-PI ................................................................. 89

$3.47 \mathrm{O}$ padre e a onça .............................................................................................. 89

3.48 Fazenda Lagoa das Pedras ................................................................................. 90

3.49 Um dia de cães! .................................................................................................. 92

3.50 A árdua disputa pelo Pampinha .................................................................... 93

3.51 Montaria com meus primos ............................................................................ 94

3.52 São muitos os meus contos! ............................................................................... 96

3.53 Minhas primeiras impressões ....................................................................... 97

3.54 Férias em minha casa Lagoa das Pedras ........................................................ 99

3.55 Voto secreto ............................................................................................................. 100 
3.56 Minha doce e inesquecível infância na casa da Vovó Estrelinha e do Vovô Manoelzinho ................................................................................................... 101

3.57 Quinze anos do sertão ....................................................................................... 103

3.58 Aí, nasceu minha paixão por cavalos ................................................................ 105

3.59 Como não lembrar?! ........................................................................................ 108

3.60 Enlaçados pelo umbigo e coração ................................................................... 111

3.61 O bode Melado, haja adrenalina! .................................................................... 115

3.62 Cilada de cunhado ............................................................................................. 119

3.63 Já chamando a vovó de mãe ............................................................................. 120

3.64 Inspeção noturna .............................................................................................. 121

3.65 A mulher era braba! ........................................................................................ 121

3.66 Babá idosa destituída do cargo ……………………....................................... 122

3.67 Momentos inesquecíveis da minha infância .................................................. 123

3.68 Seu Manoelzim e Dona Estrelinha .............................................................. 127

3.69 Convivendo com meu sogro e minha sogra .................................................... 129

3.70 Pé de umbu, nosso restaurante ....................................................................... 131

$3.71 \mathrm{Eu}$, meu pai e a lagoa... .................................................................................... 132

3.72 Cabaça d'água na cabeça, lá vai Sineide! ....................................................... 134

3.73 Minhas recordações ......................................................................................... 135

3.74 Uma ajudinha do Cupido ........................................................................... 137

3.75 Alagoano, porém, cearense de alma e coração ……………………………….. 145

3.76 Vida de vaqueiro? Vida de vaqueiro! ............................................................. 146

3.77 Momentos marcantes ......................................................................................... 149

3.78 Vovô Manoelzinho (nossas rondas) ………………………………………..... 153

3.79 Vovó Estrelinha (comer, rezar e amar) ............................................................ 154

3.80 Malu na Lagoa ................................................................................................ 154

3.81 Varanda, conversa sob a luz de lamparinas .................................................. 156

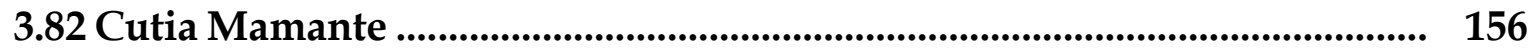

3.83 Tio caçador ……………………....................................................................... 156

3.84 Careta do boi brabo .................................................................................... 157

3.85 Pingo ….................................................................................................. 157

3.86 McDonald's da serra …................................................................................. 158 
3.87 Besouro de porre

3.88 Histórias da Fazenda Lagoa das Pedras ..................................................... $\quad 160$

3.89 A caminho da Festa de Reisados (de bicicleta) ........................................ 161

3.90 A Autoescola do Teté ...................................................................................... 162 


\section{PREFÁCIO}

A simplicidade do sertão, o aconchego da família e o carinho de seus moradores presenteiam seus frequentadores com experiências inesquecíveis. O livro "Contos da Lagoa" trata-se de um compilado de histórias vividas por diferentes gerações, em um incrível lugar, a Fazenda Lagoa das Pedras, da Família Carvalho. Ao apreciar esta obra, o leitor pratica uma terapia, mergulhando no mundo bucólico, pacato e incrível do sertão cearense, divertindo-se e emocionando-se com diversos contos de familiares e de amigos que puderam vivenciar o aconchego da Lagoa com todas as suas peculiaridades: natureza, pessoas, alegrias e dificuldades do sertão. A variedade de experiências contadas por pessoas de diferentes gerações e visões de mundo irá transmitir a magnitude da simples e amável Fazenda Lagoa das Pedras para os amantes do sertão nordestino.

Guilherme Matheus Carvalho Simplício 


\section{SOBRE OS CONTOS}

Os nossos contos serão de fundamental importância para aprender e conhecer um pouco mais dos hábitos, dos costumes e das tradições da Família Carvalho da Fazenda Lagoa das Pedras, município de Quiterianópolis-CE, pois para a Família Carvalho/Vieira/Coutinho, contar e ouvir histórias sempre foi tradição, diversão e uma forma saudável de conviver em família.

O livro é um memorial de contos, relatos, narrações e todos os tipos de escrita que a língua portuguesa nos possibilita expressar e transmitir nossas sensações e sentimentos. Foi muito prazeroso construir este livro, pois ao ouvir, contar e transcrever histórias, "causos", relatos, narrações, dissertações e poesias, diverti-me, emocionei-me, relembrei, pensei e vi, em pensamento, as cenas narradas. Quero aqui, mais uma vez, agradecer a participação especial da família, pois se assim não o fosse, esta obra não teria ficado tão rica em memórias.

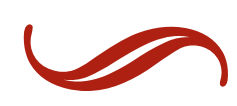




\section{MEUS PAIS}

Foto 1 - Manoel Vieira de Carvalho

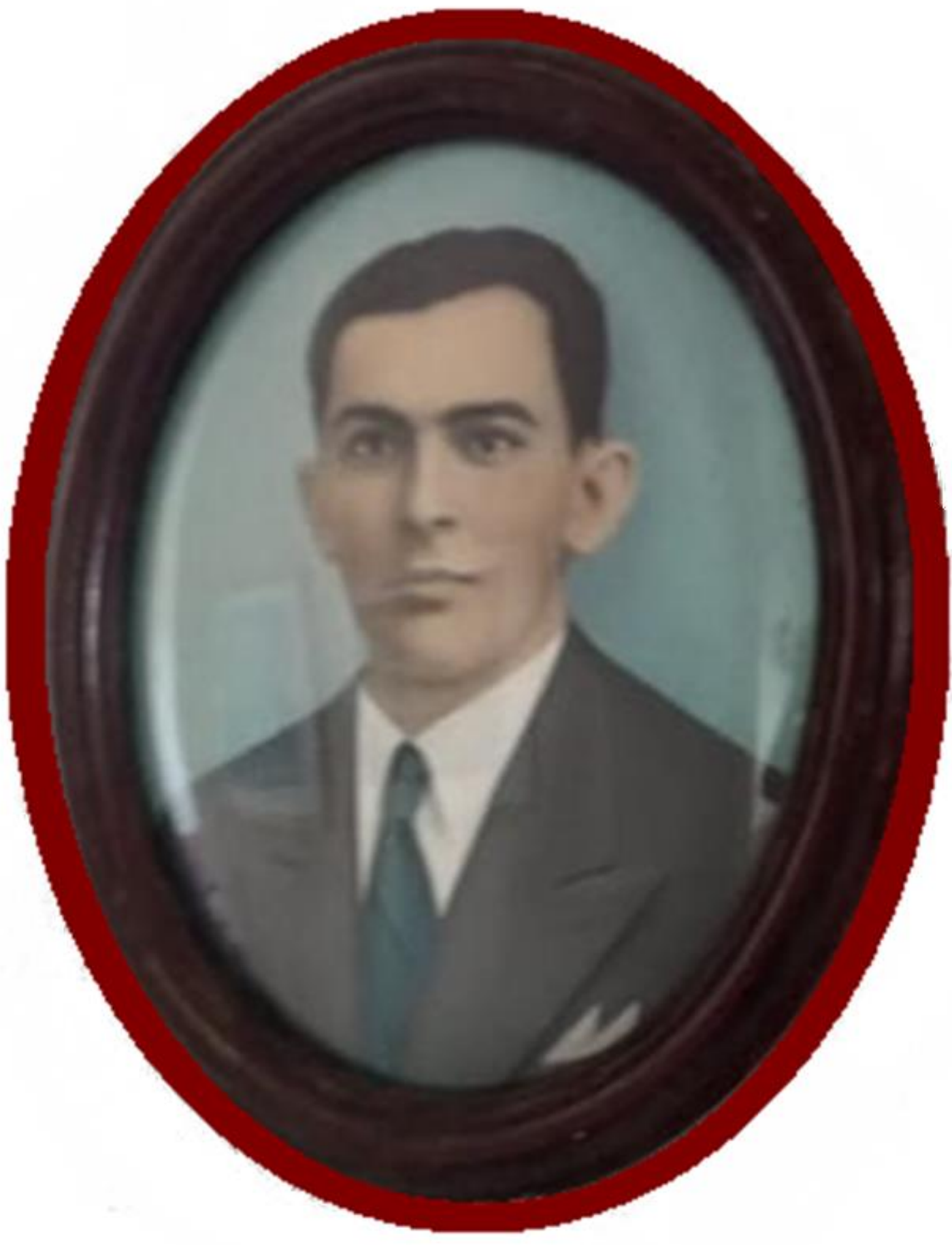

Fonte: Acervo da Família. 


\section{Manoel Wreina de Garvalho}

Homem branco, alto, esbelto, cabelos lisos de bonita fisionomia. Piauiense, nascido em 05 de dezembro de 1901, filho homem único de Maria Joaquina Vieira de Carvalho e Antônio Alves Vieira, tinha quatro irmãs: Maria dos Santos Vieira de Carvalho, Lucinda dos Anjos Vieira de Carvalho, Francisca Hortência Vieira de Carvalho e Isabel Vieira de Carvalho.

Antônio Alves Vieira, seu pai, tinha fazendas nos estados do Piauí e Ceará, para que tivesse mais opções de manejar o gado, ou seja, quando estava seco no Ceará, ele mandava o gado para o Piauí e vice-versa. De certa forma, uma boa estratégia para escapar o gado da seca.

Com o falecimento de seus pais, ainda muito jovem, aos quinze anos de idade, teve que assumir a administração de todas as fazendas da família: Lagoa das Pedras, Vitória, Queimadas, Várzea do Bessa, Umbuzeiro, Guaribas e São Gerônimo. Naquela época, as mulheres eram apenas donas de casa, pois não era costume mulheres trabalhar em outras atividades.

Após o falecimento de suas irmãs que não deixaram herdeiros, meu pai ficou com considerável herança, no entanto, nunca usando disso para obter poder. Conservou tudo que seu pai lhe deixou. Sua maior riqueza nunca foi bens materiais e sim os valores relacionados à educação e ao conhecimento, riqueza que sempre valorizou e priorizou para família, pois dizia ele: “Meu filho, o conhecimento é uma riqueza para sempre; ninguém tira de você".

Seu principal objetivo de vida sempre foi formar os filhos e conseguiu! Naquela época, nada era fácil! Colocar os filhos para estudar, por mais que a pessoa tivesse posses, não era fácil! Tudo era difícil, mas nenhum obstáculo o fez desistir.

Um homem admirável e à frente de seu tempo! Não se escandalizava com nada. Um homem humilde, manso e, ao mesmo tempo, firme em suas palavras; um esposo atencioso, zeloso, cúmplice, respeitador e muito apaixonado pela sua Estrela, como chamava mamãe. Casaram-se, ele aos 42 anos e ela aos 20, uma grande diferença de idade que não teve a menor importância. 
Um patrão querido e respeitado, tratava todos com mesmo zelo e atenção. A maioria dos moradores era seus compadres e ainda nos ensinou a chamá-los de padrinho ou tio, até hoje é assim que os tratamos. Foram muitos os seus ensinamentos, que eram exemplificados em suas atitudes rotineiras, ou seja, ensinou-nos com atitudes concretas.

Tinha um lado muito divertido, ele mesmo inventava uns truques e dava a quem chegasse à fazenda, para que durante aquela estadia, tentasse descobrir aquele mistério, o que, na maioria das vezes, não acontecia. Por exemplo, colocou uma cruz de madeira dentro de um vidro com pregos, que nem para nossa mãe ele contou o segredo, pois dizia ele que mãe sempre dá um jeitinho de contar para filho, pura verdade!

Muito caridoso, criou e ajudou muita gente, até as pessoas com doenças mentais. Trouxe alguns parentes do Piauí, como o nosso querido "Didilo", que chegou na Lagoa das Pedras, em 1958, hoje, o morador mais antigo da fazenda. Manoel Vieira não era um homem rural, no meu modo de ver, um intelectual nato. Seus hábitos eram totalmente de homem urbano; dormir de pijamas, acordar mais tarde do que o habitual no sertão, gostava muito de cidade, qualquer motivo era uma desculpa suficiente para ir a Crateús.

Homem politizado e que tinha grande influência política no município, era chamado de Capitão Manoelzinho, se recusou ser candidato único a Prefeito do Município. Naquela época, ainda Independência, justificando-o não ter conhecimento suficiente das leis. Exemplo de bom senso e sensatez!

Gostava muito de ler e nos incentivava a fazer o mesmo. Muito inteligente, praticamente um autodidata, aprendeu a ler e escrever quase sozinho, apenas com ajuda de suas irmãs, mulheres cultas, religiosas e muito inteligentes, conhecidas em toda a região.

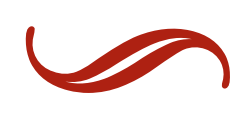


Foto 2 - Maria Estrela Coutinho Carvalho

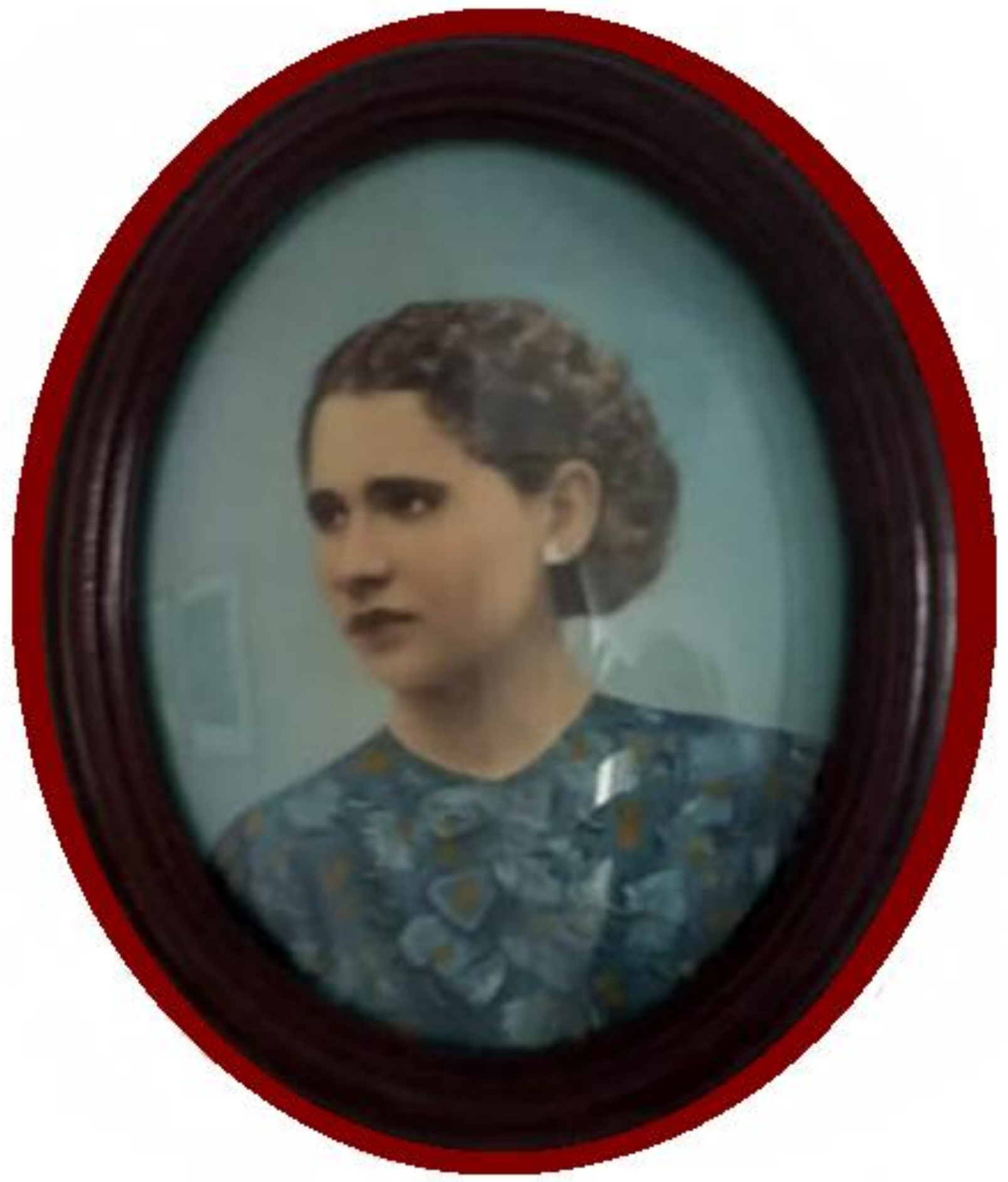

Fonte: Acervo da Família. 


\section{Maria שestrela Goutinho Gasualho}

Nascida em 31 de janeiro de 1922, na cidade de Independência-CE. A sexta filha do casal João de Deus Gomes Coutinho e Aurélia Aragão Coutinho. Era professora e tinha muito orgulho da profissão. Escrevia muito bem e com muita desenvoltura.

A moça da cidade, que se adaptou plenamente à vida do sertão. Tornou-se uma verdadeira sertaneja, até mesmo mais que meu pai, que já era da zona rural.

Seu nome era a própria descrição da sua pessoa, uma verdadeira Estrela, também chamada Rainha do Sertão. Quando jovem, uma mulher bonita, branca, cabelos cacheados, pernas grossas e cintura fina.

Uma mãe dedicadíssima e amorosa, esposa companheira, zelosa, cúmplice, atenciosa e também muito apaixonada pelo "meu velho", como carinhosamente tratava meu pai.

Uma mulher muito religiosa, trabalhadora e que administrava a casa da fazenda com muita maestria; na realidade, era a mão direita de nosso pai, que viajava muito para o Piauí, para administrar as fazendas situadas lá; ele, com muita sabedoria, a deixava no comando de tudo.

Patroa amiga e caridosa com os empregados, considerando-os como da família. Como papai, ela também era muito carismática, gostava de receber a família e amigos na fazenda.

Quando sabia que alguém iria chegar, passava toda a semana preparando tudo para a chegada daquela pessoa; era comida que não acabava mais! Doces e bolos que eram saboreados por todos, ninguém saía da fazenda sem levar seu docinho de leite e o tão desejado queijo.

Uma pessoa muito comunicativa e tinha uma veia cômica, herança da Família Aragão de sua mãe. Interagia com todas as "tribos" e sempre muito bem humorada. 
Gostava muito de conviver com as irmãs, principalmente, com a irmã Maria José, para nós, Mãe Zezé, que passava de meses na fazenda quando minha mãe estava de resguardo do nascimento de um filho. Elas eram cúmplices, muito engraçadas, divertiam-se com as coisas cômicas da família e, ainda, tinham segredinhos. Dona Estrelinha era uma mulher popular, conhecida por toda aquela região.

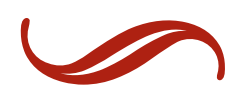


Foto 3 - O Jovem Casal Manoel Vieira de Carvalho e Maria Estrela Coutinho Carvalho

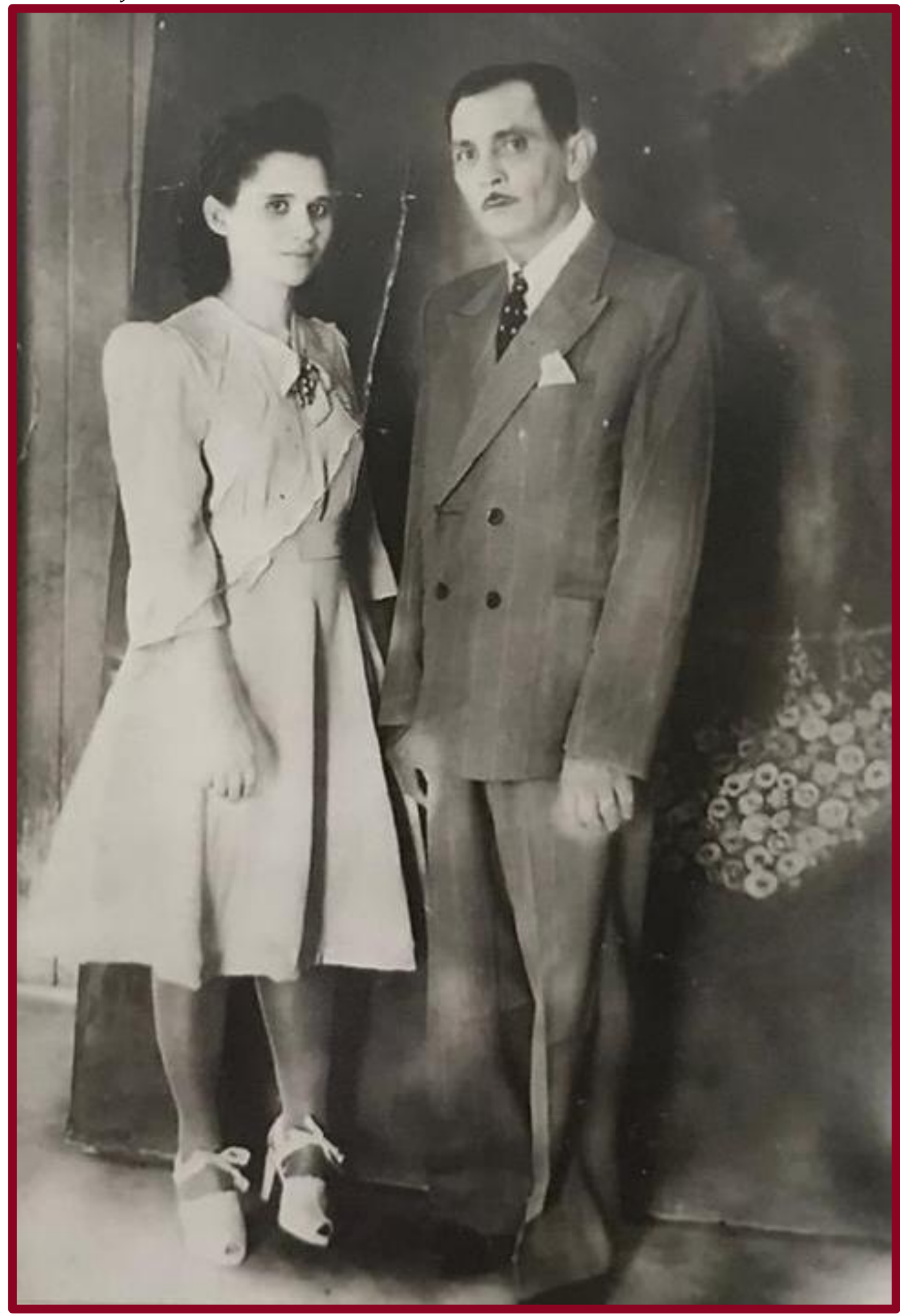

Fonte: Acervo da Família. 
Foto 4 - O Casal Manoel Vieira de Carvalho e Maria Estrela Coutinho Carvalho

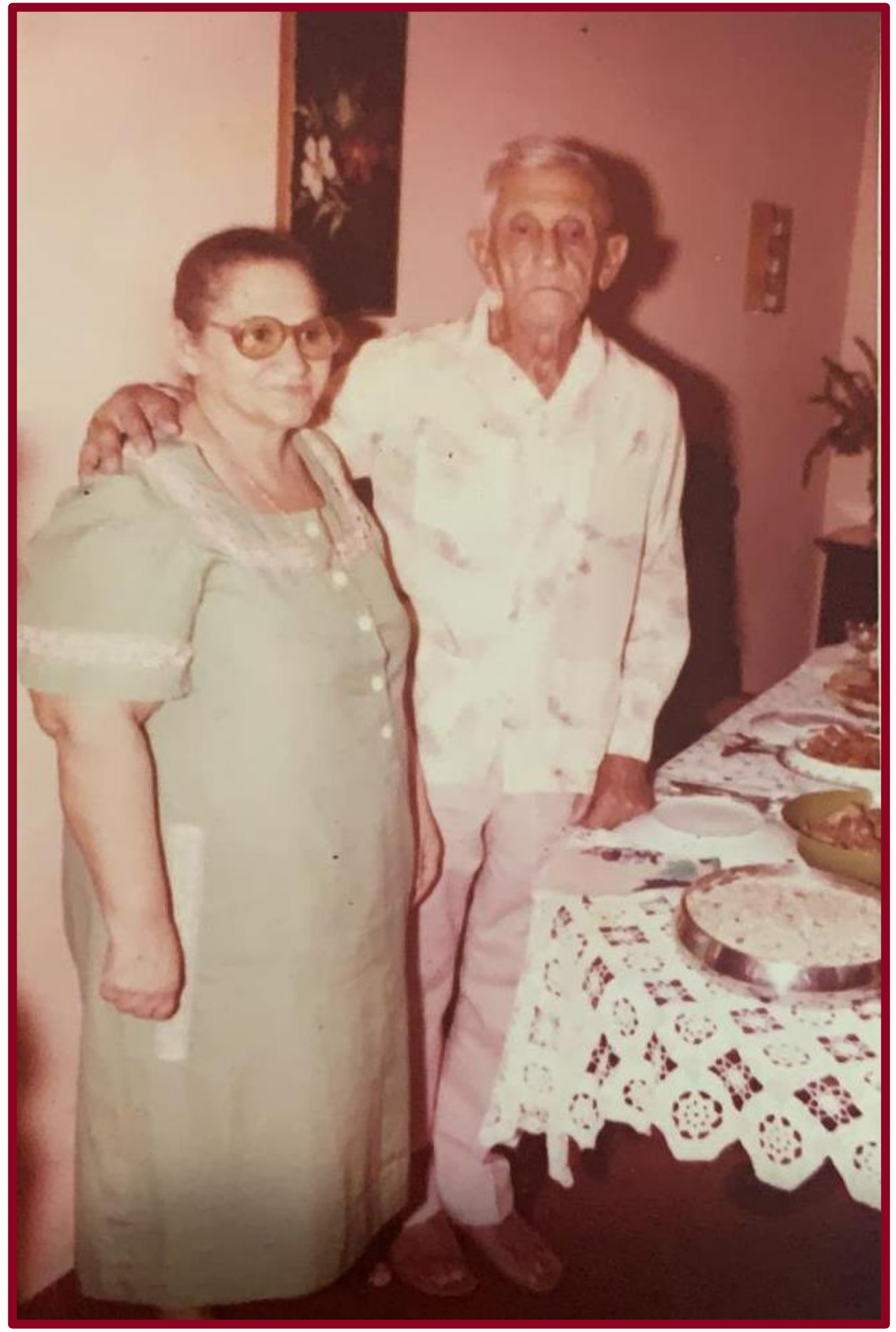

Fonte: Acervo da Família. 
Foto 5 - O Casal Manoel Vieira de Carvalho e Maria Estrela Coutinho Carvalho com seus Três Filhos Mais Velhos (Antonino, Danúbia e Lucimar)

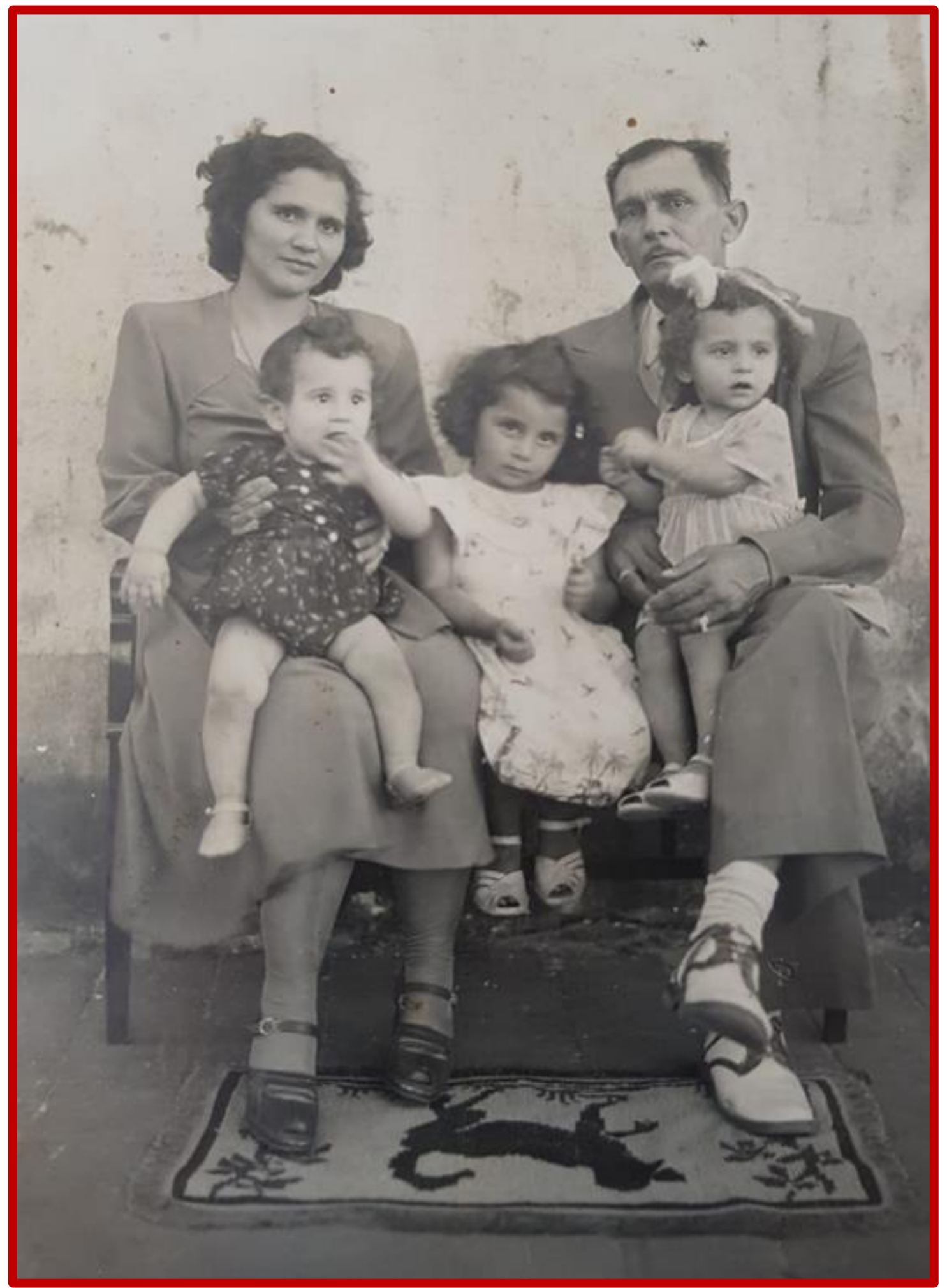

Fonte: Acervo da Família. 


\section{CONTOS}

\section{Afuretia Estela Boutinha Barrealha Oimplicia}

Administradora, advogada, nascida na Fazenda Lagoa das Pedras, casada com Augusto, com quem teve dois filhos: Camilla e Guilherme Matheus.

\subsection{O encontro inusitado de um grande amor}

Nas festas do interior, é muito comum os pais levarem as crianças junto, pois, normalmente, são festas familiares e um ambiente saudável, principalmente naquela época.

Meu pai era um homem que gostava muito de dançar. Quem o conheceu jovem, contava que, por muitas vezes, ele chegou a pagar a banda para continuar a festa até o dia amanhecer. Quando a gente pedia para ele contar esse fato, ele, com leve sorriso, desconversava.

Essa história ficou confirmada em Patos-PA, na festa de formatura da Dalvinha, onde ele deu um show de dança de salão. Foi a atração da noite! No dia seguinte, amanheceu desejando pomada para passar nas pernas.

Foi em uma festa no município de Independência, a primeira vez que ele se encontrou com minha mãe, ele com 20 anos e ela apenas com dois anos de idade.

Vovó Aurélia levou mamãe junto para um festejo e numa pequena distração, a menina saiu de perto dela. Papai vendo aquilo, pegou a criança em seus braços e a levou para sua mãe. Que coisa! São as voltas que o mundo dá.

Ouvi diversas vezes essa história, não sabia ele que aquela menina seria um dia sua esposa. Viveram unidos e felizes por 40 anos, até a partida dele e, após 10 anos, ela foi ao seu encontro.

Nunca, digo nunca presenciei eles brigarem. Claro que eles deviam ter suas divergências, mas, antes de tudo, havia um respeito mútuo. Coisa muito interessante para aquela época é que não havia qualquer submissão de nossa mãe, ao contrário, 
papai lhe dava total autonomia, inclusive delegando várias atribuições da fazenda, o que, de certa forma, acredito ter sido fundamental para as filhas se tornarem mulheres autônomas e independentes.

Pois é, aquela diferença de idade não fez qualquer diferença. Ela costumava dizer que quanto mais o tempo passava, mais gostava dele. Uma bênção. E foram muito felizes na rotina do dia a dia, que é o mais difícil!

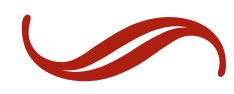


Foto 6 - Arco da Sala de Jantar assinado por Seu Manoelzinho

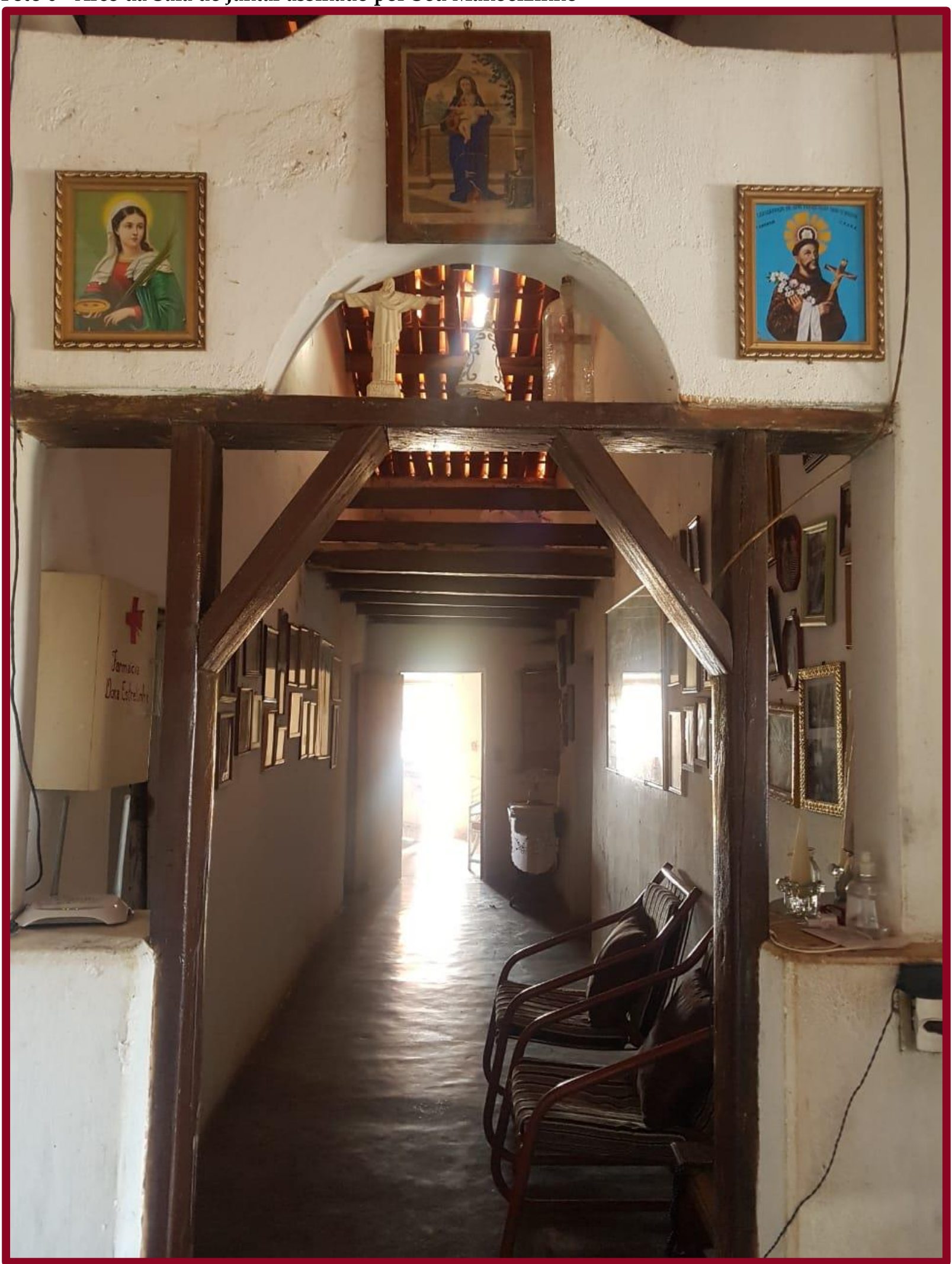

Fonte: Acervo da Família. 


\subsection{A casa da fazenda}

A casa antiga da Fazenda Lagoa das Pedras vista de longe e, na minha concepção de criança, lembrava e lembra muito o formato de um navio. Antes de meu pai casar, no espaço, havia apenas um grande armazém que passou a ser uma das salas da casa. Papai, sempre muito sem vaidade e prático, foi aumentando a casa proporcionalmente ao crescimento da família.

A frente da casa original tinha calçada alta de cimento, com bancadas e encosto de madeira, contornando toda sua frente, acompanhada de duas varandinhas laterais, uma dando para o quarto dele e a outra, com entrada em forma de arco que dá acesso, até hoje, ao quarto dos vaqueiros.

Ao entrar na porta principal, há uma sala que antes, como já disse, foi um armazém; ao lado, mais uma grande sala que é chamada de varanda, mais propriamente sala de visitas.

Um enorme corredor liga os cinco quartos, incluindo o do papai, quarto que ele sabiamente fez ligando ao quarto do casal, isso com o total apoio da mamãe, já que ela cuidava dos filhos menores juntamente com uma ajudante "babá", possibilitando, assim, mais tranquilidade para os dois, principalmente para ele que viajava muito e chegava enfadado.

Ao final do corredor, mais uma passagem em forma de arco, este de madeira que dá acesso à outra grande sala de jantar, nesta, com uma mesa grande de madeira e dois bancos, substituídos hoje por seis cadeiras talhadas em imbuia. A sala de jantar também tem uma varanda que dá acesso ao terreiro lateral, onde minha mãe gostava muito de ficar à tardinha, catando arroz e vendo o movimento da fazenda lá fora.

Saindo da sala de jantar, mais um corredor que leva à cozinha de fogão a lenha. A cozinha é comprida, com três janelas e duas portas de saída, uma para o terreiro e outra para o quintal. A casa tem uma fluidez imensa, possibilitando acesso tanto ao meio externo como aos ambientes internos. Os quartos ligavam-se uns aos outros. Uma vez, por curiosidade, contamos todas as portas internas, externas e janelas, chegando a quase setenta. 
Em toda sua extensão, a casa deixa sinais claros da inteligência arquitetônica de meu papai, por exemplo: uma janela interna na sala de visitas que abre para três ambientes: sala de visitas, corredor e sala do "armazém". Pequenas adaptações foram realizadas, mas nada que comprometesse sua essência. Foram construídos dois banheiros, um que serve a dois quartos e outro banheiro no corredor da cozinha, funcionando como social.

A casa hoje ganhou um alpendre, com bancadas em cimento e um enorme banco de madeira. Com duas entradas de carro nas laterais, dois portões grandes e um pequeno de madeira, em forma de $X$.

Ficou muito bonito, prático e aconchegante, dando conforto aos que ali se abrigam, aos passantes e visitantes, pois é como um espaço público, todos se sentem à vontade ali. A percepção que tive ao ver concluída a reforma é como se a gente tivesse guardado aquela joia de casa para nós, em uma caixa de presente.

Quero aqui ressaltar que meus irmãos homens são os maiores responsáveis por manter viva e absoluta a Fazenda Lagoa das Pedras, funcionando a todo vapor. É claro, sempre com o apoio e incentivo das irmãs mulheres que nunca colocaram qualquer obstáculo na administração da fazenda. Mesmo após o falecimento de nossos pais, aquela casa, nem por um só dia, fechou as portas. Fantástico! 


\section{Galeria: Fratos da Casa}

Foto 7 - Santuário Estrelinha

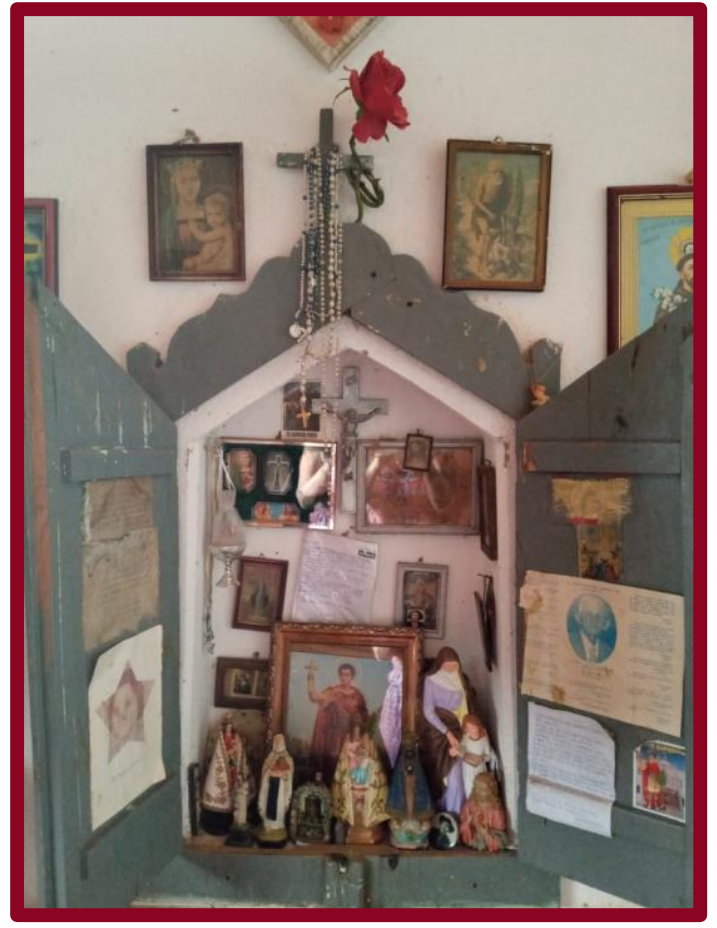

Foto 8 - Novo Alpendre

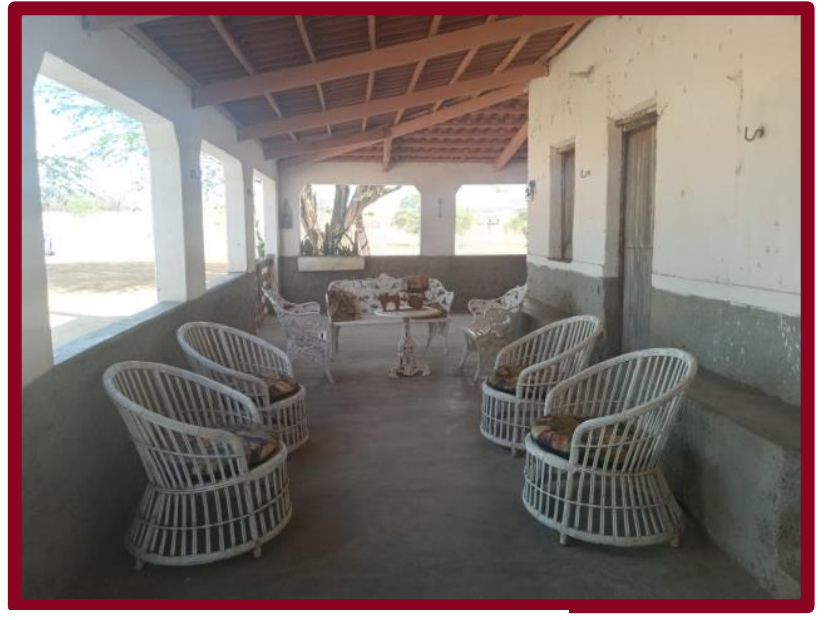

Fonte: Acervo da Família.

Fonte: Acervo da Família.

Foto 9 - Sala do Armazém

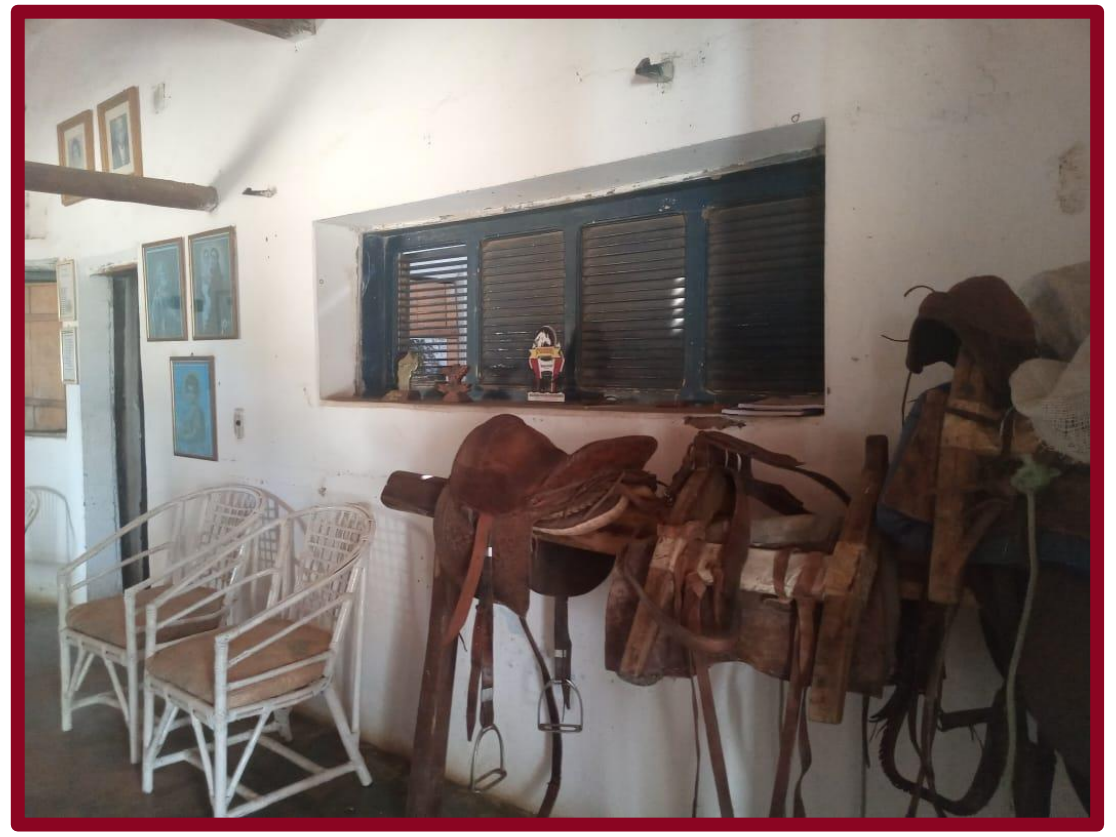

Fonte: Acervo da Família. 


\section{Galeria: Fotos da Fasa}

Foto 10 - Painel da Sala Varanda

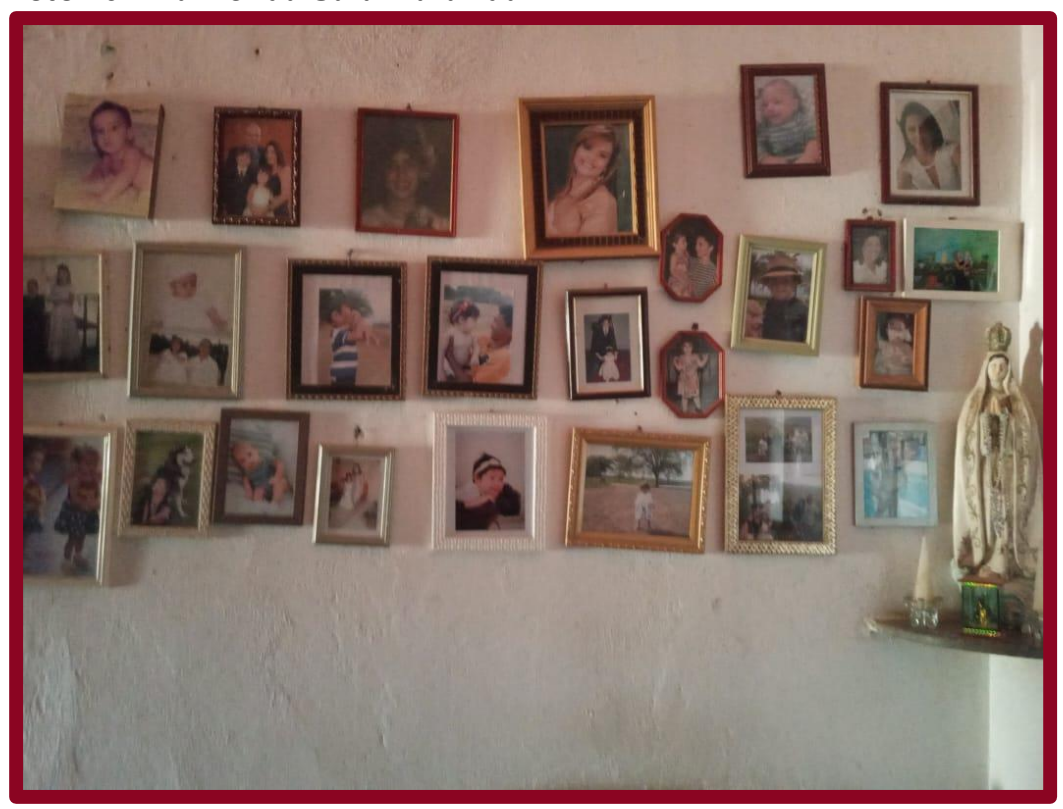

Fonte: Acervo da Família.

Foto 11 - Prensa de Fazer Queijo

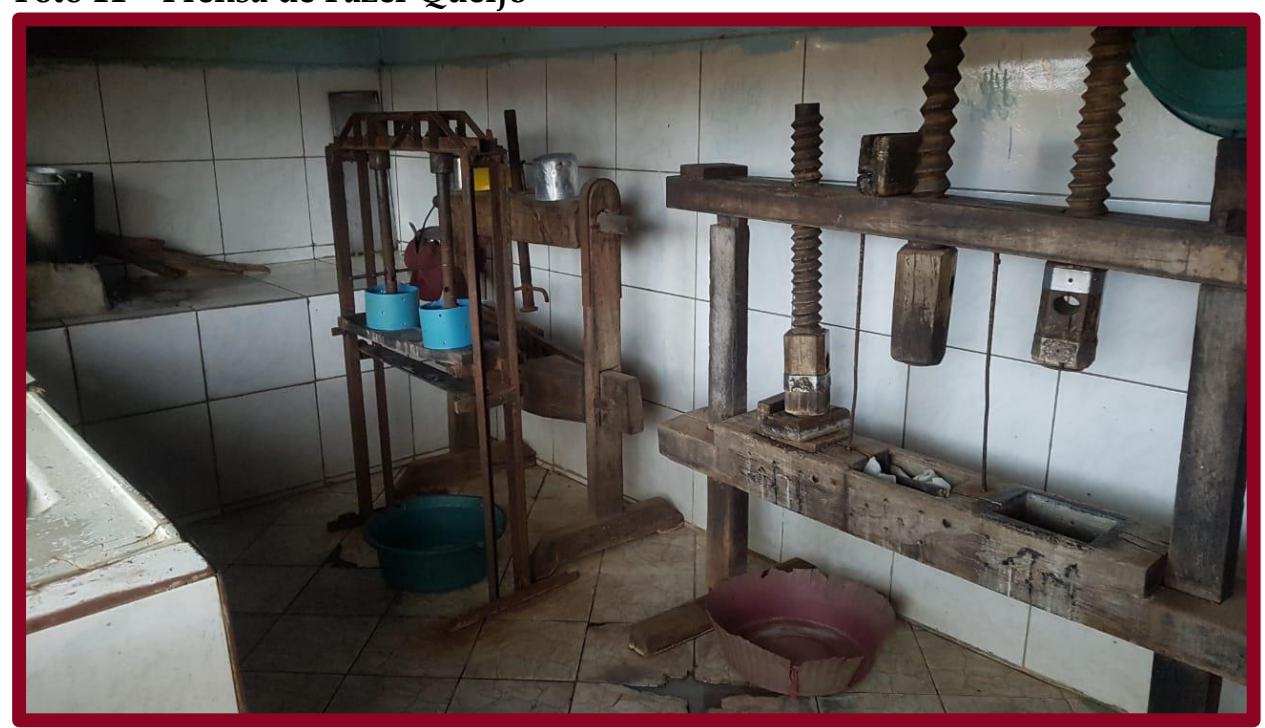

Fonte: Acervo da Família. 


\subsection{Um dia na fazenda}

Nasci e morei na Fazenda Lagoa das Pedras até meus sete anos, hoje município de Quiterianópolis. Fui alfabetizada na fazenda pela professora "Didida", moradora.

Quando chegou minha hora de ir estudar em Crateús, foi sofrido! Depois, como tudo na vida, fui me acostumando àquela nova rotina de cidade, completamente diferente da que eu estava acostumada e, ainda, longe de minha mãe. A saudade era imensa!

Lembro-me que, quando acordava e visualizava a instalação elétrica, já que a fazenda era à luz de lamparinas, tinha certeza de que não estava lá e caía na real. Malumar, minha irmã, era muito boa, mas ninguém consegue substituir o amor materno e, principalmente, o "cheirim" de mãe.

Aninha, algumas vezes, tentava me convencer que Malumar era nossa mãe de Crateús. Coitada! Queria apenas diminuir meu sofrimento, mas eu sempre retrucava, dizendo que "eu só tinha uma mãe". Muita inocência! Chegava a chorar com essa afirmação.

Quanta felicidade! Finalmente, minhas férias tinham chegado e era a hora de voltar para casa, hora de encontrar minha mãe, hora de rever meus amigos, os moradores da fazenda, que eram como se fossem da família. Eram muitos os acontecimentos, as histórias, as brincadeiras, praticamente uma aventura diária.

$\mathrm{Na}$ casa da fazenda, moravam, em média, quinze pessoas, éramos dez filhos. Sempre havia, no mínimo, três moças que moravam na fazenda e algumas moradoras que vinham para ajudar na cozinha, e três rapazes que faziam a labuta da fazenda. Alguns de meus irmãos mais velhos já moravam fora para estudar ou já estavam casados. Aquela casa era muita mais que uma família, era uma comunidade.

Mamãe cuidou da "Aiá" (Maria dos Santos) e da "Bebela" (Isabel), duas irmãs do papai já idosas; além da vovó Aurélia, sua mãe idosa e cega. Ela sempre dizia que não precisou cuidar do marido e sempre agradecia a Deus por ele ter sido um homem sadio, as doenças eram só mesmo as de idade avançada. 
Às 4 horas da matina, o galo começava a cantar, já anunciando o prenúncio do dia, acompanhado pelo aboio dos vaqueiros no curral e, principalmente, pelas batidas do pilão que preparavam o milho para o cuscuz matinal. Aquele pilão parecia uma orquestra nas mãos daquelas mulheres pisadeiras. Eram três. Tinham uma fantástica coordenação motora. As batidas do pilão e o "ram, ram, ram", quase como um gemido, soavam no silêncio da madrugada. Era como uma grande fábrica.

Aos primeiros raios de sol, já se escutava o arrastado inconfundível da sandália da minha mãe, que passava de lá para cá no corredor, que mais parecia uma pista de tanta gente que trafegava. Dava acesso ao quarto que havia dois enormes caixões de madeira que armazenavam rapadura, arroz e farinha, fruto das rendas das fazendas, como também outros alimentos, daí chamado "quarto do caixão". Ao mesmo tempo que mamãe andava para lá e para cá, pegando os mantimentos para o almoço do dia, já ia passando as diretrizes para as mulheres que cuidavam da casa, e gritava: "Francisca, você vai lavar roupa, a Roberta vai fazer o almoço e a Bela vai varrer o terreiro". Ao levantar eu já sabia de toda a programação do dia; detalhe: a chave do "quarto do caixão", "o caixa forte” era guardado no bolso do vestido dela.

Ao me levantar, feliz, ao ver que o dia tinha amanhecido, a primeira coisa que fazia era ir pedir a bênção aos meus pais, era uma tradição, uma obrigação, porém, muito gratificante, pois era um momento de bênçãos e aconchego. Meu pai, muito amável e ainda deitado, pedia que a gente ficasse deitado um pouquinho ao lado dele para esquentar seu frio; aqueles cinco minutos uma eternidade para mim, pois a fazenda já estava a todo vapor e já me preocupava com o tempo que estava perdendo, pois sabia que algumas crianças já estavam brincando.

Depois de um puxado café da manhã, o chamado quebra o jejum, começava a labuta para o almoço, não era uma coisa simples! Pois, naquela época, não havia água encanada, energia elétrica. Nunca naquela casa almoçavam menos de vinte pessoas, isso quando não tinham os adjuntos de trabalhadores de roça com até vinte e trinta homens, sem falar nos vaqueiros, com boiadas vindas do sertão, que se arranchavam lá. Não era qualquer simples almocinho, mas um grande evento. Estou falando de um dia comum e rotineiro, pois quando era um daqueles dias especiais, como a matança de um boi, carneiro, ovelha e porco, para o consumo doméstico, a movimentação era 
altíssima! A gente se levantava bem cedinho para ver a matança, já pensou? Sem qualquer trauma. Engraçado, as crianças viam aquele ato como algo natural, fazia parte da cultura alimentar.

Para as crianças, um dia de festa, já para os adultos, um dia de muito trabalho: fazer almoço para muitos, apurar a gordura do animal, pois era com o óleo de porco que se faziam os alimentos. Quando o animal era grande, apuravam-se de vinte a trinta garrafas de óleo, que minha mãe armazenava no velho e bom "quarto do caixão" para uma boa temporada. Dias que pareciam bem mais compridos, almoçavam, no mínimo, trinta pessoas, porque além dos da casa, muitos dos moradores vinham também almoçar e pegar seu pedacinho de carne. Na realidade, era um dia de festa e partilha.

E, aí, chega a hora de preparar o jantar, jantar, praticamente, preestabelecido: baião de dois, mungunzá, arroz de leite; a carninha de gado moída era feita especialmente para papai, mas nada que não pudéssemos compartilhar. Quando chegava um filho que estudava fora ou um outro familiar, aí, menino, entrava no menu a iguaria, carro-chefe da fazenda, a galinha caipira cozida, hum! Não tem quem faça igual.

Após o jantar, todos eram convidados, democraticamente, para rezar o terço. Os homens, à francesa, iam se deslocando para o habitual encontro na calçada. Quem acompanhava o terço também se encaminhava para o quarto da mamãe, onde havia um oratório, preservado até hoje. Era lá que rezávamos o terço. Algumas das mulheres, cansadas com a labuta doméstica, já cochilavam. Mamãe fazia vista grossa e já se dava por satisfeita da intenção da pessoa, pois o importante mesmo era estar de corpo presente. Na grande maioria das vezes, eu dormia. Acredito mesmo que o terço alcançou muitas graças na nossa família, pois graças a Deus e as orações da nossa mãe, sempre tivemos uma vida sem grandes problemas e olhem que éramos dez filhos, não é pouca coisa! Até hoje, tentamos sempre que possível, rezar o terço.

Terço finalizado, os que tinham escapado do sono eram chamados para o momento social, chegara o "point do dia", o encontro na calçada da família com moradores da fazenda e amigos da redondeza, para aquele bom e saudável papo, falar dos acontecidos do dia e das histórias, principalmente papai que era quem mais 
gostava. Ele tinha o dom da narração, fazia com todos os detalhes, sempre fazendo questão de lembrar os nomes dos personagens, sem esquecer de nenhum. Tinha uma excelente memória! Lembro-me que conseguia visualizar toda a cena do conto por ele interpretado.

Escutava as "estórias", se tivesse chance no colo de minha mãe, pois era muito disputado por Aninha e Carvalho, mas como caçula, sempre tinha mais vez. No colo de minha mãe, olhando para as estrelas e flagrando a queda dos esteroides que para nós eram apenas estrelas. Um espetáculo à parte, um teatro imaginário e a grande tela era apenas o céu.

O som das conversas ia ficando cada vez mais baixinho, até que sumia de vez, era quando eu adormecia no colo de minha mãe e, aí, era só esperar o dia raiar novamente, começando um novo dia e uma nova movimentação.

Saí para estudar, mas minhas raízes ficaram fincadas profundamente naquele chão, de forma tal que até hoje percebo que é preciso recarregar plenamente minha energia lá.

Imagino que minhas colegas de ontem e hoje nunca conseguiram entender o porquê da minha grande ligação com a fazenda. Explicar? Jamais entenderiam! Tenho tanto amor a este lugar, que resolvi multiplicar fazendo uma casinha de barro. Augusto e eu construímos o Rancho Mucunã. É uma linda casinha de barro que amo estar lá. Uma construção inacabada, quando digo inacabada é porque sempre estou mudando e inventando algo novo. O Rancho Mucunã é como o sertão, reinventa-se dia a dia, troca a pele como um camaleão, acho que é por isso que me encanta tanto. Lá eu viro criança. É como se estivesse brincando de casinha. Faço café para os que passam e sinto que para os moradores também é uma diversão. É uma extensão da Casa Sede (Fazenda), como eles se referem à casa da Fazenda. O Carvalho diz que o Rancho é a Jeri do Sertão, por sua decoração rústica, reciclada e ao mesmo tempo com um toque de modernidade. Pois é, a Lagoa já deu e continua dando muitos frutos, como é o caso da Carnaúbas João e Tonino e do meu amado Rancho Mucunã. É só o começo.

Tantos anos se passaram! Fico muito feliz e agradecida, principalmente aos meus irmãos que cuidaram da fazenda até hoje, como nossos pais, possibilitando, 
dessa forma, vivenciarmos os dias atuais com a riqueza do passado. Sinto-me privilegiada de poder conviver com meus irmãos, aquela gente, aquele lugar tão abençoado que sempre acolheu e acolhe até hoje, os familiares, sejam parentes ou amigos, sem qualquer distinção.

Hoje, temos, no comando da casa, principalmente da cozinha, já há quase 25 anos, Marismar, uma mulher de quase 70 anos, com uma energia de uma mulher de 20. De uma voz altiva, um colhimento caloroso e não tem papas na língua! As frases chavões dela: "tem rumo não" e "vai dá certo".

É a feitora principal do queijo, faz o almoço e fica até às 14 horas, até a entrada de uma outra duplinha de mãe e filha, Valdirene e Olávia, para fazer o laboro da tarde. Os rapazes que cuidam do manejo do gado são: Eudes, Bel e Rayone (neto do tio Virgílio). Essa equipe muda de acordo com as mudanças de vida deles, como é o caso de casarem, por exemplo.

Muitas coisas ou quase tudo mudou, só não mudou aquela energia boa, aquela simplicidade de viver, aquele amor verdadeiro que só se multiplica, deixado e ensinado por meus pais, está lá, do mesmo jeitinho, disponível para todos, é só ir, oportunizar, sentir e aproveitar, pois está no ar.

Rogo a Deus que minhas próximas gerações hão de vivenciar para conhecer um pouquinho daquele lugar e poder aprender com aquelas pessoas, vivenciar um pouco as novas "estórias" da Fazenda Lagoa das Pedras que muito tem a nos ensinar e nos enriquecer como seres humanos. A Fazenda Lagoa das Pedras permanecerá geograficamente no mesmo lugar, o que mudará são as pessoas, os personagens, as histórias, pois é vida que segue...

\subsection{Aiá e Bebela}

Minhas tias, Maria dos Santos (Aiá) e Isabel (Bebela), depois de idosas, moraram durante um bom tempo com a gente. Aiá já muito velinha, não tinha mais como morar sozinha, e Bebela que morava com seu esposo, tio Chiquinho, no Piauí, depois que enviuvou, veio para o Ceará. 
Eram mulheres cultas, educadas e muito religiosas, criaram também muita gente. Muito respeitadas pela religiosidade. Eram médicas homeopáticas, rezavam e faziam nas pessoas tratamento homeopático. Vinha gente de toda região em busca das pilulazinhas bentas e milagrosas.

Elas eram muito carismáticas! Chamavam as pessoas de "minha nega" e "meu nego". Aiá morou mais tempo na fazenda do que Bebela. Quando já estava velinha, teve Alzheimer. Não queria nada que não viesse de Roma. Era uma graça!

Mamãe, muito criativa, inventava para ela que o Papa havia mandado uma caixa de leite e tudo mais que ela precisava, só dessa forma, ela aceitava. Ela gostava muito da mamãe e confiava plenamente, ainda bem!

Bebela, quando chegou do Piauí, também já tinha Alzheimer. Elas sabiam muita história do Brasil e de Portugal. Adoravam recitar poesias e eram sabedoras de muitos ditados populares. Os sobrinhos curtiam muito a presença delas. Ficaram na Lagoa das Pedras até falecerem.

3.4.1 Algumas de suas histórias...

\subsubsection{Amor ao próximo}

Bebela, também foi sempre muito caridosa e com imenso amor ao próximo, contam quem esteve no seu convívio que ela arregimentou muitos homens, com toda infraestrutura, para tentar encontrar a velhinha Raquel que se perdeu na chapada do Umbuzeiro/PI, mas, infelizmente, foi encontrada morta. Mostrando aí seu gesto de grandeza.

Aiá, puro amor ao próximo. Elas criaram muita gente, evitando, dessa forma, que gente morresse de fome. As duas tratavam as crianças com homeopatia, tudo de forma voluntária e, ainda, fazendo a doação de remédios e alimentos. 


\subsubsection{Visita ao "Padim Padim Ciço"}

Contavam os moradores que Bebela fez uma viagem a cavalo com uma comitiva grande, para visitar o "Padim Ciço", no Juazeiro, a 600 km da Fazenda Lagoa das Pedras, uma grande aventura! Conversou com "Padim Ciço", falaram de família; ele a recebeu de modo protocolar e com muita gentileza. Houve até troca de presentes. Infelizmente, não me lembro de mais detalhes, mas, assim, mostro como elas eram determinadas.

\subsection{Meus galos não estão à venda!}

Mamãe criava muitas aves: patos, galinhas, capotes, pavão, tinha até um jaboti velho que papai trouxe do Piauí, era a sensação da criançada, pois subíamos nele e ele andava com a gente, era nosso transporte (Uber) da época.

O terreiro era lindo, cheio de galinhas com pintinhos, capotes. Durante o inverno, tanto na casa fazenda como na casa dos moradores, ela deitava as galinhas (colocar para chocar os ovos), chamada ninhada, aí, era aquela fartura de pintinhos que com seis meses, os que escapavam estavam adultos, prontos para o abate, eram castrados, chamados de capão. Alguns deles virariam galos.

Havia muitos deles, alguns morriam de velhos. Mamãe tinha muita consideração pelos seus reprodutores, por isso nunca iam para a panela.

Papai já idoso se aborrecia com os galos, pois ele tinha um soninho depois do almoço e os bichos costumavam se aglomerar perto do quarto, fazendo, já sabem, aquela cantoria. Lembro-me que ele tinha até um chicote para espantar os bichos.

Certa vez, passando por Novo Oriente, um senhor comprador de aves perguntou ao meu pai se era verdade que mamãe tinha muitos galos, ele the respondeu que sim e contou que os bichos eram muito barulhentos. O senhor indagou ao papai se ela não venderia algum dos galos, pois ele tinha interesse. Papai, doido para se livrar deles, sugeriu que ele fosse até a fazenda para falar com ela e deu aquela força para que ele comprasse alguns. 
O comprador de galos, recomendado por papai, tirou um dia e foi até à Lagoa das Pedras fazer proposta de compra para mamãe. Chegando lá, foi muito bem recebido por ela e, como era de costume, mamãe perguntou o motivo da ida à fazenda, ainda avisando que papai não se encontrava lá.

O homem, sabendo disso, disse que havia o encontrado em Novo Oriente e que ele disse para o mesmo que ela tinha um "batalhão" de galos, dando a ideia que fosse à fazenda fazer proposta de compra.

E foi, então, que o comprador de galos fez a proposta, imediatamente recusada por ela. Ela disse que seus galos eram de estima e que eles iam morrer de velhos, para o desânimo do homem. Depois de um farto almoço e um rápido descanso, o senhor voltou de mãos abanando.

Quando papai chegou do Piauí, certo da venda dos galos, mamãe o indagou se aquela história do comprador era verdade. Afirmou papai que sim, tinha mesmo dado a ideia para ele, achando até mesmo que ela iria gostar. E ela disse a ele o seguinte: "Manoelzinho, cuide do seu gado; dos meus galos cuido eu e eles não estão à venda." Pois é, não foi dessa vez que papai se livrou dos galos, os bichinhos morreram de velhos.

\subsection{O pavio do rádio}

Era costume mãe Zezé passar temporadas na Lagoa, eram muito cúmplices e amigas. Naquela época, o único meio de comunicação eram as cartas e os bilhetes (pequenos recados). Mamãe costumava fazer longas cartas para Lucimar, em Crateús, com uma lista de compras, remédios, tecidos e outras necessidades. O pêndulo do rádio tinha quebrado e ela estava fazendo uma carta para Malumar, exatamente para mandar consertá-lo, mas, na hora de escrever o nome da peça, não lembrava, foi quando chamou mãe Zezé e perguntou se ela sabia o nome daquela peça. Mãe Zezé pensou, pensou, mas não lembrou. Depois de um bom tempo, elas tentando lembrar, sem êxito, mãe Zezé disse: Estrelinha, bote, aí, pavio. E, assim, foi feito: "Minha filha vai o rádio para você mandar ajeitar o pavio". Imaginem! Malumar ficou sem saber que pavio era aquele. 


\subsection{Pescoço de galinha}

Apesar de sermos 10 filhos, pois dois haviam falecido ainda bebês, mamãe sempre nos tratou diferenciadamente, ou seja, lidava com cada um de nós, respeitando nossas diferenças. Lembro-me muito de um fato que ela contava muito, pois achava muito interessante aquilo.

Como falei, ela agradava cada um de nós, proporcionando aquilo que gostávamos, por exemplo: guardar um tipo de bolo, fruta, etc. que gostávamos, fazia isso constantemente, com diversas coisas.

Antônio Luiz gostava muito da coxinha e a titela da galinha, ela cuidadosamente fazia o possível para deixar para ele. Muitos de nós também queríamos a coxinha, lembro-me que ela me dizia: “minha filha, a galinha só tinha uma perna!" Eu, inocentemente, acreditava e até ficava com dó da galinha.

Certo dia, chegou um povo de fora para almoçar sem mamãe estar esperando. Nesse dia, mataram só uma galinha, aí, não teve jeito, Toinho ficou sem seus pedaços preferidos, ficou mesmo como o pescoço da galinha.

Contava ela que ele lhe fez um pedido: "que quando só sobrasse o pescoço, ela não precisava colocar carne para ele, não tinha nenhum problema". Ela achou aquilo muito interessante.

\subsection{As escapadas da tia Ferreira}

Tia Ferreira era a mulher do tio Ferreira, moradores antigos da fazenda. Ela era uma pessoa com a autoestima lá em cima, dizia que só comia manteiga da boa. Gostava de passear, não perdia uma oportunidade. Sempre que chagava na fazenda, papai perguntava a ela pelo tio Ferreira, preocupado com ele, pois já eram idosos. Tia Ferreira dizia que tinha "deixado o velho embolachado" (lanchado), ou seja, almoçado. Essa frase virou refrão para a família, qualquer preocupação com alimento para membros da família, dizíamos que já estava "embolachado". 


\subsection{Trapaceando as crianças}

Essa da tia Ferreira também era muito boa! Ela era aquela pessoa folgada, sempre ficava com as tarefas mais leves e prazerosas, era também muito inteligente, tem uma frase dela que é famosa: “... menino, eu só quero é escapar”. Gostava muito de passear em Crateús, na casa da Malumar, as crianças gostavam muito dela. Raquel e Christiane adoravam brincar com ela. Vejam só, as meninas com 8 e 10 anos, e ela com 70 anos. Uma das brincadeiras preferidas era a de parto cesariano, as meninas eram as médicas e ela, a paciente; sugeria às médicas para aplicar anestesia geral para o parto, as médicas prontamente anestesiavam e, aí, só dava para ela, dormia a tarde toda!

\subsection{Cavalo ou parede do açude?}

A Lagoa das Pedras era uma casa muito acolhedora, eles acolheram e criaram muita gente, inclusive doente mental, como foi o caso da Nazaré (Lelé). Assis, uma figurinha inesquecível e meio "doido", muito engraçado, passou uma temporada na Lagoa. Foi criado por uma irmã da mamãe, tia Raimundinha, dona da Fazenda Floresta, do município de Independência-CE. Com seu falecimento, Assis veio morar na Lagoa das Pedras, passou uns 10 anos, depois com o falecimento do papai, ele veio para Fortaleza. Até hoje, temos contato com ele. Um dia, estava um senhor procurando um cavalo vermelho que havia sumido, querendo saber do papai, se algum morador teria visto o cavalo. Papai, sabendo que Assis andava muito, mandou chamá-lo e perguntou se ele teria visto o tal cavalo, fazendo a descrição detalhada do cavalo, inclusive da cor dele. Naquele ano, havia sido feito o açude velho, como é chamado hoje, e a parede ainda era cor de barro, não havendo crescido qualquer vegetação, como é de costume. Assis pensou bem na pergunta e respondeu: "tio Manoelzinho, eu vi sim, se não for o cavalo, é a parede do açude”. Todos caíram na risada e papai disse: “esse nego é maluquim!” E, assim, foram muitas as figuras emblemáticas que viveram ou passaram naquele lugar. 


\subsection{Cacimba d'água}

Mamãe teve inúmeras colaboradoras que moraram dez, vinte anos com ela, já eram da família. Foram muitas: tia Ludugera, Roberta, Zumira, madrinha Maria, Bela, Luzia e muitas outras, como também haviam morado na casa rapazes para a labuta da fazenda: Virgílio, Antônio Dantas, Pedro Mariano, Manoel, Assis e outros que agora, não recordo. Aconteceram muitas paixões e casamento dessa turma; moças e rapazes juntos não dá outra. Por exemplo: tia Ludugera casou-se com Virgílio (Didilo), e aí vai.

Quando algum deles se casava, minha mãe fazia um grande almoço de casamento, era um dia de festa. Houve um casamento de uma delas: madrinha Maria, uma moça muito bonita, de cabelos longos. O casamento com Miranda, outra "figurinha" emblemática. Foi realizado na casa da fazenda. O padre veio exclusivamente para fazer o casamento.

Mamãe fez um grande almoço oferecido aos noivos, com a presença das famílias dos noivos e dos moradores da fazenda. $\mathrm{O}$ almoço foi servido, depois da sobremesa, tinha o café, acompanhado com um bom bate-papo. Papai, ao perguntar pelo noivo que não se fazia presente à conversa, foi surpreendido ao ser avisado que Miranda tinha tirado a roupa do casamento e tinha ido cavar uma cacimba d'água no rio. Ele imediatamente mandou chamar o noivo. Quando Miranda chegou, papai disse a ele: "Rapaz, você deixa os convidados e sai sem falar nada". Ele, já de roupa de trabalho, disse: “É, Seu Manoelzinho, fui fazer uma cacimba para minha mulher, pois não quero mulher minha brigando por água na cacimba dos outros". "Figurinha!"

\subsection{Deixando Juiz de Direito sem palavras}

Papai contou muito a história de um "cabra" lá para os lados do sertão da Independência, grande produtor de milho e feijão e conhecido por ser homem destemido e de não levar desaforo para casa.

Certa vez, encontrou porcos do vizinho dentro de suas roças, mandou avisar que ele viesse e retirasse os porcos da roça, pois os bichos estavam acabando 
com o legume. Mandou avisar por duas vezes, na terceira vez, ele mesmo foi lá e atirou nos porcos, matando-os.

O vizinho nada satisfeito com aquilo, entrou com uma ação na justiça contra ele. Passou-se um tempo, quando chegou a intimação para que ele comparecesse ao juizado. E, assim, ele fez, foi para a Independência, no dia marcado, e compareceu à audiência.

A audiência ocorreu normalmente, o Juiz perguntou se ele tinha mesmo matado os porcos do vizinho, o homem sem "tutubiá" (titubear) confirmou que sim. Ficando sem defesa, foi feito um despacho, para que fossem feitos os cálculos do valor da causa.

Nos valores de hoje, por exemplo, daria um total de $\mathrm{R} \$ 700,00$ (setecentos reais). O homem sempre calado, retirou $\mathrm{R} \$ 1.000,00$ (mil reais) do bolso, pagou o prejuízo e foi logo se levantando para ir embora.

Foi quando o Juiz alertou a ele que aguardasse, pois havia troco. Imediatamente, o senhor virou-se e disse ao Juiz de Direito: “Não, Doutor, o Senhor fique logo com o troco, pois eu sei que ao chegar lá, vou encontrar porco na minha roça, sendo assim, já fica pago". O Juiz ficou surpreso, sem saber o que dizer! 


\section{Trancisca QDalua Meira de Gavealho}

Filha, engenheira agrônoma, nascida na Fazenda Lagoa das Pedras. Tem duas filhas: Marianna e Julianna, e três netos: Benício, Isaac e Lívia.

\subsection{Lagoa das Pedras de todos}

Lagoa das Pedras dos Carvalhos, das Lagoas da Madian Aga, funda e carão, do pé de umbu, dos Romanos e Tenentes, da Carnaúba, Mucunã, Canto e Muquém. De Maria Joaquina, Antônio Vieira, Manoel Carvalho e Estrela, dos Franciscos, Manoeis, Antônios e Joões, das Marias dos Santos, Danúbia e Lucindas; Aurélia, Hortência, Isabel e Sebastião.

Lagoa das Pedras, da porteira das flores, dos boiadeiros e passantes, dos currais, terreiros e bancadas entre o sertão e a serra; banhada pelo Poti: das enchentes, poço da ponte, jaramataias, cajás, oiticica; balneário de crianças.

Lagoa das Pedras da fazenda (locais de orações) e casa nova, lugar de brancos e negros, compadres, tios e padrinhos (tios Ferreira, Raimunda, Vicente, Águida, César, Cícero Joaquina, Branco, Francisca, Raimunda do Branco, Manoel Natividade, Miranda e mãe Joana, minha mãe de leite).

Lagoa das Pedras dos vaqueiros aboiadores e famosos: Virgílio Carvalho Dantas e Vicentinho Irineu. Do levantar do dia com o tinido dos chocalhos, canto de galos, burburinhos, aboios saudosos e penosos com canto de passarinho.

Lagoa das Pedras de labutas, resiliência e vida cangaceira, como dizia mamãe; de alegria e tristeza, do pilão de Nazaré (Lelê), de rebanho de capote que chegava a trezentos, do cheiro da flor do mofumbo e do Pereira.

Lagoa das Pedras do acolhimento, dos doentes, idosos, viúvas, crianças e dos desamparados; Lagoa das Pedras das saídas e chegadas, noites estreladas, lúdico lugar no nosso imaginário, o melhor lugar do mundo. 
Lagoa das Pedras das novas gerações que energizam sua vida, colorem e pintam como arco-íris seus cenários e horizontes.

Lagoa das Pedras que estampa nas paredes antepassados, longevidade, descendência e crença, em uma linda história de nossos avós, tios e do amor dos nossos pais, raiz e matriz de tudo que somos. Te amo, apenas!

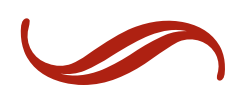




\section{Maria OKlenixa Rodrigues Macédo}

Sobrinha, advogada, filha de Cleyde e Joaquim, tem duas filhas: Larissa e Ludmila.

\subsection{Memórias de um fim de férias}

Era final de fevereiro, beirando março, aproximava-se a volta às aulas e, de repente, as férias de 1966 foram oficialmente encerradas por um telegrama vindo de Fortaleza, enviado por meu saudoso pai e repassado de Crateús pela tão querida Mãe Zezé, frisada em letras garrafais a palavra "URGENTE".

Portanto, não havia mais argumento para esticar um pouquinho que fosse aquele período maravilhoso de carinhoso convívio com nossos tios, primos Carvalhos, moradores e vizinhos da Fazenda Lagoa das Pedras.

Mas, a urgência da volta seria medida pelo grande inverno que havia se instalado nos sertões, para a alegria de todos e, especialmente, das crianças. A festa das águas, curtíamos desde o princípio, o cheiro reconfortante e inconfundível da terra molhada, o rio Poti, que deslizava em seu leito atrás da casa, tomando água pouco a pouco, os caldeirões das lajes, cheios de cágados e tetéus tinindo para cima e para baixo.

A prima Lucimar nos levava com frequência a passeatas no mato, onde as brincadeiras variavam em tomar banho no rio, banho de chuva, procurar ninho de capota entre mandacarus, xique-xique, juremas e aroeiras. Reunidos aos Carvalhos, passeávamos pelas veredas, apreciando o "chap chap" dos pés, na lama que se formava. Sempre havia um medinho de nos depararmos com cobras, até vimos algumas de tabuleiro e, uma única vez, vi uma coral, enquanto tejos corriam apressados com a nossa aproximação.

Mas, como disse, veio a ordem sem jeito para voltar para Fortaleza, e a mim e ao meu irmão Carlinho, mais novo do que eu um ano, só restava com tristeza 
assistirmos aos preparativos da viagem de regresso programada pelos bondosos tios Estrelinha e Manoelzinho.

Foi um "invernão", cheia para todo lado. O Poti, em sua glória, saía da calha ultrapassando as margens, invadindo várzeas e porteiras, mostrando uma braveza imensa! Impossível passar carro e atravessá-lo até a estrada mais próxima. Tudo, então, foi planejado para nos levarem a cavalo até a Independência e sermos entregues aos cuidados da memorável tia Alfa.

Chegou o dia da viagem, a tropa comandada por Virgílio, a quem os pequenos chamavam Didilo, Pedro Mariano, eu (Kikira) e Carlinhos, montados a cavalos ou em burro, não recordo esse detalhe.

Alforjes abastecidos com rapadura quebradinha e paçoca de carne seca, sob o olhar de todos ali reunidos, da menineira e adultos que se plantaram no terreiro da aconchegante casa da inesquecível Lagoa das Pedras, seguiu-se o inevitável adeus, os desígnios de boa viagem, choros, abraços nos tios e primos sempre queridos e demais pessoas queridas que conviviam conosco durante as férias.

Partimos! Olhei para trás até a dobra da estrada no pé de umbu, sentindo uma saudade imensa, o choro baixinho, contido, enquanto Virgílio falava, "beija-fulô", cuidado para não escorregar.

A viagem obedecia a um trotar ritmado dos animais, começando a chuva aos poucos a castigar, enquanto a saudade se mesclava ao espírito de aventura, pois tudo era novo, eu nunca havia viajado a cavalo.

Entre pedregulhos, moitas caídas e muita água, atravessamos um riacho de águas ligeiras, onde Virgílio ia nadando e puxando os cabrestos das montarias e eu e Carlinhos, ora com medo, ora com muita alegria, seguindo as ordens do nosso chefe de viagem: "segurem firme, não batam os pés na água"! Aquilo tudo era inédito em nossas vidas, que aventura teríamos para contar aos nossos e também na escola!

Virgílio era cheio de cuidados, falava e logo obedecíamos, para que não houvesse "atrapalhos" (empecilhos) no decorrer da viagem. Ele levava a turma com rigor, mas com bondade e bem querer. Lembro que, ao atravessarmos o dito riacho, eles já cansados, pedi para ver um ninho numa moita de mofumbo, onde vi um cabeçavermelha pousar. Nunca esqueci o gesto daquele momento. Ele poderia dizer: “Não, 
nós precisamos ir em frente, a viagem é longa e logo vai escurecer", mas, pelo contrário, ele me atendeu e lá fui eu xeretar o ninho com ovinhos, cuidando para não tocá-los, para evitar que a mamãe passarinha os abandonasse ao apetite de alguma cobra.

E foi também naquele riacho, depois da trabalhosa travessia que o Carlinhos falou ter deixado o par de sandálias do outro lado e lá se foi o Virgílio nadar para ir pegar.

Naquela noite, fomos muito bem recebidos na fazenda Catingueiro, jantamos e fomos dormir entre lençóis e cheirosas redes brancas. No dia seguinte, após um farto café, prosseguimos a venturosa viagem até o nosso destino, sempre acompanhados pela chuva e do nosso bom Deus!

A chegada à pequena Independência foi numa tarde triunfal, depois do longo trajeto percorrido, nos esperava tia Alfa, entre abraços, mimos, sequilhos, coalhada, charutinhos, pão de ló e café com leite bem quentinho! Ainda chovia, mas estávamos em casa, terra firme, dispostos a em breve seguir para Crateús, de onde partiríamos para Fortaleza. 


\section{MSaria Eestrela Ganvealho MSachado de Gastro}

Neta, psicóloga, filha de João de Deus e Ângela, casada com Nailton, tem um filho.

\subsection{Férias com meus avós}

Já trago em meu nome a referência de minha avó paterna, Maria Estrela, com muito orgulho! Relatar sobre a Lagoa das Pedras é falar de origem, de raízes. Foi lá toda a construção de afinidade da nossa Família Carvalho, afinidade que foi estendida às novas gerações. Tenho muitas lembranças boas a resgatar de minha memória, memórias antigas e para sempre.

Minha família residia em Crateús, mas meu pai sempre se dividindo entre a fazenda e Crateús. Em Crateús, o objetivo era estar com a família. Íamos muito em finais de semana e nas férias para a Lagoa das Pedras.

Lembro-me como se fosse hoje, às quatro da madrugada, minha mãe nos acordando para pegar a estrada. Naquele tempo, a estrada ainda era de barro, a viagem era longa, porém não impedia que fôssemos felizes. Ao chegar, vovó estava a nos esperar com um delicioso almoço, doce de leite e muito amor. De noite era de praxe rezar o terço com a participação de Dona Chaguinha e as demais ajudantes da vovó, umas já cochilando, mas o importante era estar presente.

Minhas férias era toda lá, usufruí muito dos banhos de rio, pulando de cima das oiticicas. No inverno, a passagem no rio, tanto em nossa chegada como na volta para casa, era de boia, uma verdadeira aventura para uma criança. A água do rio, muitas vezes, chegava à cancela que ficava bem próximo da casa da fazenda, tão perto que ao anoitecer, podíamos escutar o barulho das águas. A gente ficava colocando pauzinho para ver se a água estava aumentando ou diminuindo. Tinha também a procura dos ovos de capote nas moitas, fazíamos até disputa para ver quem achava mais e vovó sempre nos incentivando, ora, ora, ela queria mesmo era os ovos. 
O ninho dos passarinhos era o que mais me encantava e, até hoje, sou apaixonada. Quantos natais na Lagoa! Indo dormir na expectativa da passagem do Papai Noel. As brincadeiras de casinha embaixo do pé de umbu. À noite, vovó já separava tudo que a gente ia levar para fazer o almoço, a comida ficava a pura fumaça! Isso foi tão marcante, que até hoje me emociono quando lembro.

$\mathrm{O}$ encontro com os primos e os tios, as rodas de conversa à noite no alpendre, as brincadeiras no terreiro e, ainda, com uma plateia de adultos. A chegada do "Padim" Vicente da Serra trazendo manga... hum! Era bom demais! Eram muitas as aventuras: a chegada dos vaqueiros de outras fazendas que lá se arranchavam com suas boiadas, as idas bem cedinho ao curral para tomar leite mugido; ir para a casa do tio Virgílio comer o cuscuz delicioso que a tia Francisca fazia, amarrado no pano e cozido no fogareiro; as idas e vindas à casa da Dona Socorro, ver a tia Raimunda fazendo renda; chegava lá e pedia para tomar de conta da cozinha; a ida para o catecismo, isso aí, vovó não dispensava! A subida nas pedras das lajes, parece que estou até sentindo a emoção e o ventinho no rosto, os passeios ao Catingueiro para a casa da Netinha e do Coutinho, viagem planejada por uma semana, até que parecia que íamos para outro país.

E meus amigos de infância? Também não esqueço! Cheirosa, Aninha, Liduína Cheiro, Lerim; criamos laços de afetividade e, hoje, somos comadres e compadres. Um dos passeios que gostava muito era de ir à Carnaúba (bairro da Lagoa), cedinho com minha amiga Cheirosa, íamos passear por lá, achava lindo o caminho no inverno, cheio de pés de milho. Chegando lá, era recebida carinhosamente por Dona Francisca (tia Pantica), aí, tinha o almoço, o lanche, eram as bruacas (bolo de goma); de lá íamos para casa da tia Raimunda do Branco, nos esperando com seu bom suquinho de pacote, a bichinha! Pois é, gente, a Carnaúba como falei, foram momentos de minhas férias que me marcaram muito; acredito mesmo que nada é por acaso, pois hoje a Carnaúba é minha outra casa, onde moram meus pais e minha avó materna.

Hoje, continuo indo para a Fazenda Lagoa das Pedras, mais especificamente para Carnaúba. Quando estou indo na estrada, passa um filme em minha cabeça, é um eterno reviver; admiro o pé de juazeiro, a baixa da cacimba da tia Raimunda e as cancelas da casa Sede para a casa da Carnaúba, que não são poucas! 
O tempo passa, as coisas se modificam, mas as lembranças continuam vivas e ficam para sempre. Hoje é meu filho que está vivenciando tudo que vivenciei. Lembro-me ainda que nas minhas voltas de férias para Crateús, era muito choro, muita saudade da vovó e do lugar, ela preparava uma caixa com todos os agrados e não podiam faltar as cartinhas para minha mãe.

O que posso dizer é que tudo passa, tudo se modifica, mas as lembranças ficam para sempre. O lugar, a casa da Lagoa das Pedras, tem uma linda e rica história. Meus avós hoje não estão mais presentes fisicamente, porém presentes na alma! Quero aqui destacar meu pai João de Deus, que passou toda a sua vida ao lado de seus pais e com a ausência dos mesmos, passou a conviver com seus irmãos, tio Antônio Luiz e tio Carvalho, hoje acho tudo a cara deles.

A casa continua com a mesma "logomarca", é a casa de todos, dando continuidade ao legado que meus avós deixaram: amor, acolhimento, receptividade, honestidade, respeito, gratidão, empatia e os princípios do bem viver. Todos que ali chegavam, gostavam e se apaixonavam e voltavam, porque lá tinha e tem uma energia positiva, o bem-estar.

Hoje, sou feliz porque tive a sorte e a oportunidade de usufruir do convívio com meus avós, Manoelzinho e Estrelinha. Seus cuidados e seu imenso amor nos fizeram pessoas melhores.

Muito bom ter vivido naquele sertão, com tantas coisas boas. Tudo era lúdico! Hoje, infelizmente, as crianças não desfrutam do melhor da vida, a simplicidade.

Onde meus avós estiverem, devem estar muito felizes por ver sua família unida, cada dia mais presente na fazenda, ou seja, na casa que eles construíram com todo amor, a qual continua viva, a todo vapor, incrível!!

Que as relações de afetividade, amor, respeito, empatia e cuidado com o outro prevaleçam entre nós. Não somos uma família perfeita, mas temos o melhor: que é tentar vencer as diferenças e as adversidades, restabelecendo nossas relações familiares com respeito e amor.

A Família Carvalho, da Fazenda Lagoa das Pedras, para sempre será nosso referencial.

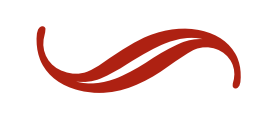




\section{Antônia Pluizg Goutinho Gaswalka}

Filho, economista e agropecuarista, nascido na Fazenda Lagoa das Pedras. Casado com Sandra Maria, tem duas filhas: Hortência e Laryssa.

\subsection{Exemplo de solidariedade}

Vou relatar aqui uma história que me marcou muito, uma das histórias das ações e da caridade do nosso saudoso pai Manoel Vieira Carvalho. Eu tinha 16 anos, foi no ano de 1970, em meados do mês de junho, já havia sido declarada a seca no Ceará. Naquele tempo, o sertanejo perdeu todas as suas roças na flor, o milho já bonecado, aí, minha gente, foi uma calamidade, e de amparo naquele tempo, só mesmo alguns bolsões, chamados frente de serviço em Independência e Novo Oriente, com vagas reduzidas, em que ficaram muitas famílias sem qualquer amparo.

Estávamos na Lagoa das Pedras, numa tardinha, no final de julho, quando avistamos duas famílias, vindo do sentido do Catingueiro Lagoa das Pedras, cada uma com uma criança de colo, o casal tinha em média 30 anos de idade. As mulheres traziam uma trouxa na cabeça e uma criança no quarto e os homens com um "mantulão" (uma rede com seus pertences atravessado no peito como uma mochila), eram retirantes da região do Iapi. Percebemos que estavam muito fadigados da viagem, porém, sem qualquer reclamação, como é característica do homem do campo, não reclamar.

Papai, vendo aquela situação, automaticamente deu rancho e alimentação para aquelas famílias e deixou tudo o que estava fazendo, voltando-se, totalmente, para aquela situação que o comoveu muito. Começou a perguntar de onde eles estavam vindo e para onde pretendiam ir. Na conversa, eles disseram que estavam fugindo da seca, não tinham conseguido vaga nas frentes de serviço e que estavam indo à procura de uns parentes que tinham ido embora para Água Branca, no Piauí, em 1958, vejam só! Já há doze anos. Papai, sabendo disso, ficou admirado e preocupado, pois conhecia o lugar, onde já tinha comprado gado e sabia da distância 
e, de imediato, disse que eles não tinham como ir no dia seguinte, pois era muito longe, dizendo ele: "vocês vão esperar que vou melhorar a viagem de vocês".

No dia seguinte, deixou tudo que tinha para fazer e mandou chamar o Seu Manoel Natividade e Virgílio para juntamente com ele providenciarem umas cangalhas e, assim, fizeram, passaram o dia em função da viagem dos retirantes: arrumou os jacás com alimento, uma terça de farinha, rapadura, uma teça de feijão vermelho; também mandou o tio Ferreira pegar uma cabra lá no Seu Chico, vaqueiro das criações, dizendo ele que ou eles comiam ou vendiam. Tio Ferreira trouxe uma cabra mista (cabra preta e branca).

Depois de tudo pronto, na hora da saída, ele mesmo arrumou a bagagem das famílias nos jumentinhos, de uma forma que proporcionasse maior conforto para aquelas famílias: pegou as trouxas das mulheres e colocou no meio das cangalhas, sentando as crianças no meio das cargas, já tirando, dessa forma, o peso das mulheres; amarrou a cabra no cabeçote das cangalhas; lembro-me como se fosse hoje!

Eles ficaram muito gratos, não sabiam como agradecer e agradeceram da forma mais comum, ou seja, que "Só Deus pagava por aquela ajuda". Quando já se distanciavam da casa da fazenda, um dos homens se virou e perguntou: "Seu Manoelzinho, e os jumentos?" Só lembrando, que naquele tempo, o jumentinho tinha uma grande importância, pois era um importante meio de transporte do sertão. Ele se virou, levantando as calças e respondeu: "se vocês voltarem, tragam, se não, está resolvido!"

O que mais me admirou foi sua generosidade, pois não teve nenhuma intenção em qualquer retorno, pura caridade! Todas as condições materiais que ele proporcionou para aquelas famílias, qualquer uma pessoa com condição financeira e boa vontade, poderia fazer, mas o que mais me impressionou foi ele ter tirado um dia inteiro para ficar, exclusivamente, em função daquelas famílias. Uma atitude de pura nobreza, pois ele podia muito bem mandar alguém fazer tudo aquilo. 


\subsection{Isso é que é ter compromisso!}

Lembro-me de uma história de compromisso de meu pai. Papai estava nas Queimadas-PI. Ele sempre ia ao Piauí e tinha a cultura de trazer aquelas pessoas de lá que considerava mais fragilizadas, até mesmo com a intenção de ajudá-las. Manuel Lucade, ainda hoje mora nas Queimadas-PI, e é testemunha do que vou contar. Manoel Lucade foi criado por sua avó, chamada de Lucade, daí o apelido. Parteira do lugar e conhecida por todos, costumava chamar papai de "meu branco".

Quando papai já se preparava para vir embora para o Ceará, disse: “Lucade, me dê esse menino pra eu levar pro Ceará?" Ela respondeu que não podia dar, pois aquele menino era seu único companheiro. Com aquela resposta, papai respondeu que não tinha problema, pois levaria ela também. Dona Lucada disse que não podia ir, pois estava velha e não tinha mais serventia e, principalmente, porque tinha feito uma promessa de ser enterrada no Galheiro-PI. Meu pai achou aquilo interessante e disse a ela brincando que isso não seria problema, pois quando ela morresse, ele mandaria salgar o corpo e mandava o Branco deixá-la no Galheiro para ser enterrada. Branco era um morador da Fazenda Lagoa das Pedras, que logo disse: "não faça isso comigo, compadre Manoelzim". Ele tinha muito medo de alma. Ficaram naquela brincadeira e ficou por isso mesmo.

Papai veio embora e, uns dois anos depois, soube que Dona Lucade tinha falecido, ela teria saído de casa para visitar uns parentes, naquela mesma região, a uma distância de uns três quilômetros das Queimadas, durante o passeio, Lucade caiu nos grutilhões do Piauí e perdeu-se, sem nunca ter sido encontrada. Um caçador achou o corpo dela uns dois meses depois. Papai ficou sabendo por meio de Cícero, que contou também que eles acharam por bem enterrar Lucade lá mesmo.

Papai, lembrando da promessa dela, ou seja, de ser enterrada no Galheiro, motivo de não querer vir para o Ceará com ele, mandou-o fazer um caixãozinho de madeira e mandou Cícero trazer os ossos de Lucade para enterrar no Galheiro. Cícero resgatou os restos mortais com todo cuidado e trouxe para enterrar no Galheiro, que era o desejo dela; mandou ainda convidar seus familiares para fazer um enterro com toda dignidade. Só para vocês entenderem como nosso pai era um homem de 
compromisso. Dona Lucade nem veio para o Ceará, mas como ele era sabedor desse desejo dela, fez questão de realizar.

\subsection{Brincadeiras sertanejas}

Tivemos uma infância muito boa na Lagoa, eram muitos amigos, na realidade, a fazenda como um todo era uma grande comunidade; os filhos dos moradores eram quase como se fossem nossos irmãos, alguns, nossos irmãos de leite. Era considerado irmão de leite aquele que tinha nascido no mesmo ano da gente e que a mãe chegou a nos amamentar. Naquela época, havia esse costume, as mães que tinham filhos no mesmo ano, amamentavam os filhos umas das outras.

Além das crianças da fazenda, tinham, ainda, os meninos do Monteiro, Calixto, Jatobá; era menino que não acabava mais! Tínhamos algumas brincadeiras bem arriscadas! Pular das árvores quando o rio estava cheio, disputar corrida com jumentos, descer nas barreiras. Houve um tempo que Tião inventou um rodeio de montar em jumento brabo, como funcionava? Colocávamos os jumentos mais brabos no curral para ver quem tinha coragem de montar, quem demorasse mais tempo sem cair, era o vencedor.

Tínhamos um amigo chamado Sebastião, filho do Branco, daí Sebastião do Branco que era muito mole, medroso e chorão. Naquele dia, o desafiamos a montar no jumento e, para não passar por medroso, Tiãozinho topou. Logo colocou Sebastião em cima do jumento e amarrou as pernas dele por baixo do animal, imaginem só? Não tinha como dar certo. Estávamos certos de que ele estava seguro em cima do jumento. Quando soltamos o jumento, ele começou a pular desesperadamente, como quem queria se livrar daquela carga em cima dele, Sebastião. Imediatamente, Sebastião virou de cabeça para baixo, ficamos apavorados e pedimos socorro ao padrinho Ferreira, quase que matamos nosso amigo. Quando finalmente tio Ferreira conseguiu parar o jumento, Sebastião, coitadinho, saiu todo ralado, cego, cego e chorou muito. 
Tião, muito esperto, foi logo pegar queijo com rapadura, pois, naquela época, era o melhor calmante, tudo isso era para ele não contar para a mamãe. Só sei de uma coisa: Sebastião passou uns seis meses comendo queijo com rapadura, pois sempre que ele ameaçava contar para a mamãe, a gente corria para pegar queijo com rapadura. 


\section{Antonia Freancisco Oreira Gavealho (Antanina)}

Filho, economista, nascido na Fazenda Lagoa das Pedras, atualmente residindo em Natal-RN, casado com Maria de Fátima Monte Carvalho, pai de Henrique Alexandre Monte Carvalho e avô de Cecília de Lima Carvalho e Laura de Lima Carvalho.

\subsection{Da Lamparina à Internet}

Antes do alvorecer, já se escutava a voz da mamãe acordando suas colaboradoras, Rosa, Chica Ludugera, Guilhermínia, Hozarina, Toinha do Branco e tantas outras, para a lida diária. A iluminação ficava por conta da velha lamparina. Não demorava, começava o ritmo do pilão (como descrito por Jakson do Pandeiro, na música "Casaca de Couro"), preparando o pão de milho para o café da manhã. No curral, os tiradores de leite, Vicentão, Vicentinho, Pequeno e outros cuidavam da ordenha das vacas.

Ao longo do dia, seguia-se a rotina do sertão, com serviços domésticos, manejo de animais e, dependendo da época, serviços de broca, plantio, tratos culturais e colheita da safra, completando o ciclo de produção. O papai sempre como grande gestor da fazenda. À noite, era habitual o bom papo na calçada. Papai sempre no comando geral, com suas boas "estórias".

Vou contar algumas delas, a família deve conhecer, mas sempre é bom relembrar e, agora, deixar registrado, melhor ainda!

\subsection{O valentão das Alagoas}

Em mais uma de suas viagens para compra de gado no estado do Piauí, estava meu pai a fazer negócio na Fazenda Baixão, de propriedade do Senhor Raimundo Lima, homem muito educado, distinto e acolhedor. 
Estavam eles no alpendre, deitados nas redes de tucuns, que no sertão costumam ficar permanentemente armadas no alpendre, batendo aquele papo enquanto os vaqueiros juntavam o gado no curral, quando chegou um forasteiro e rispidamente falou para o dono da casa: “Traga um copo pra mim”. Papai que estava ali perto, já não gostou daquela atitude do homem.

Imediatamente, o Senhor Raimundo Lima se dirigiu ao lugar dos copos para pegar a água. Ao entregar água ao moço, perguntou: “De onde é vós mincê é?" Pergunta de praxe nos sertões, até como forma de saldar e interagir com a pessoa. $\mathrm{O}$ homem não gostando da pergunta, de maneira grosseira respondeu: “... das Alagoas, esse povo do Piauí, ou povo assombrado! Onde a gente chega é querendo saber quem é, de onde vem e pra onde vai". Seu Raimundo Lima sem retrucar adentrou para guardar o copo.

Nesse ínterim, papai que estava a ouvir a conversa, incomodou-se com aquela grosseria com o dono da casa, que o atendeu com toda presteza, levantou-se da rede, dirigiu-se a ele e falou, devidamente preparado para qualquer reação do desconhecido: “Eu não vou nem perguntar quem é você, pois já vi só pela resposta que deu ao dono da casa; porque quando chega alguém estranho em nossa casa, temos mesmo que perguntar quem é, porque se for uma pessoa de bem, tratamos como uma pessoa de bem, se for vagabundo, tratamos como vagabundo. Fique sabendo que o povo do Piauí não é um povo assombrado não, eu, por exemplo, sou daqui e não tenho medo de você. Preste atenção! Se continuar dando essa resposta por aí, vai acabar levando muita peia".

Ao terminar a fala fervorosa com o desconhecido, sem o mesmo retrucar uma só palavra, o homem surpreendeu meu pai ao perguntar humildemente: “A mincê tem aí um pedacinho de fumo?" Papai respondeu que sim, atendendo seu pedido de imediato.

Esse gesto de humildade desarmou completamente meu pai, que tinha ficado irritado com aquela atitude inicial do desconhecido. Lembrei-me do ditado popular que diz: "cachorro que late, não morde". 
Depois, ao comentar com Seu Raimundo Lima o que tinha dito ao forasteiro, ele comentou: “Seu Manoelzinho, eu achei foi bom”. Papai sempre contava esse episódio por ter ficado admirado com a mudança radical do valentão.

\subsection{Carneiro parido com dois cabritinhos!}

Dedé, neto da Mãe Zezé, nosso primo guardado do lado esquerdo do peito, quando criança, passando as férias na Lagoa das Pedras, encontrou no cercado uma ovelha parida. Veio correndo e disse: “Tio Manoelzinho, encontrei um carneiro parido com dois cabritinhos". Papai adorava esse conto, creio que continua relatando lá no reino dos céus.

\subsection{Galope desastrado}

Francisco Evânio, neto da Mãe Zezé, outro primo querido por todos, foi a uma viagem ao Catingueiro com papai montando no cavalinho da Aiá, bem mansinho, um sonho. Aiá, já velinha, cavalgava no cavalinho, em sela de banda. Para apressar o ritmo do cavalo, Evânio deu uma chicotada e o cavalo começou com um galope, derrubando o cavaleiro. Para não ficar com fama de mole, Evânio pediu ao papai para não contar a ninguém o que havia acontecido. Em vão, relatava sempre que surgia oportunidade.

\subsection{Tibelo}

Mãe Zezé, muito querida e de saudosa memória. Na empresa de ônibus de Seu Hilton, trabalhava um cobrador conhecido como "tio Belo". Certa vez, papai falando do tio Belo, Mãe Zezé, em tom de gozação, comentou: “Manoelzinho, eu não conhecia este seu tio Belo". Papai olhou para ela e disse: "Maria José, ele é meu tio, é seu tio e é tio de todo mundo". Foi uma gargalhada só! 


\subsection{4 "Cibazol de muié" bordar}

Tio Ferreira, um morador dos mais antigos e queridos. Muito ingênuo, a pedido da mamãe, foi a Quiterianópolis, na época, Vila Coutinho, comprar um bastidor de mulher bordar. Na saída, para não esquecer, mamãe reforçou: “compadre Ferreira, diga que é bastidor de mulher bordar". Naquela época, Cibazol era um medicamento muito conhecido que era comercializado em todo lugar. Tio Ferreira, chegando ao comércio, pediu "Cibazol de muié bordar". O comerciante, achando estranho, tentou consertar: "não seria bastidor de mulher bordar?" Tio Ferreira retrucou e com toda certeza disse: "não, a muié disse que é Cibazol de muié bordar". Como não tinha este produto disponível no comércio, tio Ferreira voltou sem a encomenda. Mamãe se divertiu muito contando esse episódio.

\subsection{Revólver, só faz medo de longe}

Senhor Zé Romana, exímio contador de "causos". Sapateador, cantador de festas de Santos Reis, tocador de pífano, "rezador de espinhela caída" (quando o paciente se encontra com as arcas comprometidas), doenças de mulher, dentre outras; além do ofício de agricultor.

Talentosíssimo, transformava seus contos em verdadeiras peças teatrais. Ao contar as "estórias", mudava a entonação da voz, criava situação para ilustrar a cena em riqueza de detalhes com expressão corporal e tudo mais que dispunha para o conto ficar compreensivo e chamar a atenção de quem estava escutando. Suas histórias eram contadas para uma boa plateia, a risadaria era grande.

Conforme o caso, convidava alguém presente para atuar como seu assistente de palco durante a apresentação, ou seja, fazia uma cena ilustrativa, por exemplo: demonstrar como ele "avoou na munheca de um cabra para tomar-lhe o revólver", isso, durante uma corrida de cavalos no beco da Santa Rosa. Mamãe, assistindo ao episódio do revólver, comentou: "compadre, você teve muita sorte de ter escapado". Seu Zé Romana respondeu calmamente: “cumade, revólver só faz medo de longe. "Se um cabra puxar o revólver, a mincê fique emrriba, aguarre na munheca do 
caba, bote o cano para riba que não vale nada!" Mamãe respondeu: "Deus me livre de me acontecer uma coisa dessas". Assim era o saudoso e querido Zé Romana, um verdadeiro showman do sertão.

\subsection{Oh! Que negócio desmantelado!}

Vaqueiro das porcas, que morava para o lado do Catingueiro, há tempos não aparecia. Passando rapidamente pela Lagoa das Pedras, da estrada mesmo, papai perguntou como ia a criação dos porcos, caminhando, sem cortar merenda, respondeu; "a última porca morreu ano passado". Papai tinha informação de que a coisa estava desmantelada. Apesar do fracasso do negócio, papai achou a resposta engraçada, mas muito sincera. “Causo" que adorava contar.

\subsection{O especial cachorro Jacuí}

Padrinho Vicente ou "Vicentão da Serra", outra figura emblemática da fazenda, vaqueiro por muitos anos. A vida inteira morando na Lagoa das Pedras e na Serra de São Jerônimo, sempre em nosso convívio. Extremamente amável com as pessoas. Era daquelas pessoas de bem com a vida, parece até que não tinha problemas. Tinha uma fama de só chegar atrasado, logo conversava muito, contando "causos". Adorava cachorro. Durante uma de suas viagens em Crateús, comprou um cachorro chamado Jacuí. De volta à Lagoa das Pedras, com o cachorro, papai perguntou:

\footnotetext{
“-E este cachorro, Vicentão?

-Comprei, compadre Manezim.

-Mas, homem, você já tem uma ruma de cachorros.

-Ah, mas o Jacuí é especial, muito bom de caça.

-E, quanto custou?

- Tantos mil reis (equivalentes ao valor de um bezerro)."
} 
Papai ficou pasmo, perplexo, escandalizado e dizia: "Oh! Nego besta!" Mesmo assim, levou numa boa, pois o negócio já tinha sido feito.

Dias depois, papai se arranchou na casa do pessoal a quem padrinho Vicente havia comprado o Jacuí. Mundo pequeno! Ao falar do cachorro, a dona da casa disse que estava com muita saudade do Jacuí. Papai perguntou a ela se o cachorro era bom de caça. A mulher respondeu que não. Ele era muito preguiçoso, mas era um bom companheiro das mulheres quando iam pegar água de beber na cacimba.

\subsection{Web.causo.com}

Usuário "Z" "dos de nós" - ao gravar um áudio, um áudio no celular, diz: "menina, aonde é que nós bota o dedo pra falar? Tá pronto? Hum?! Pode falar? Vai gravando e perguntando, o bicho tá falando". Ao final, tudo ok!

Inobstante a toda evolução social e tecnologia, a casa da Lagoa das Pedras continua sendo um ponto de aconchego para o encontro das pessoas, simbolizado nas figuras inesquecíveis de "Seu Manoelzinho e Dona Estrelinha".

E assim são muitos os "causos" contados e recontados. Aqui apenas uma pequena amostra da coletânea de contos.

O tempo passou e com ele vieram as mudanças: asfalto, energia, água encanada, televisão, jumento substituído por motos na montaria e até para manejar o gado e, por último, o celular, enfim, tudo que a vida moderna oferece que vai mudando os hábitos e costumes.

Hoje, a Internet está presente na vida de todos da fazenda. Redes sociais, compartilhar, gravar áudio, senha do Wi-Fi, WhatsApp são termos incorporados ao vocabulário do sertão. Quanta mudança! Quem diria!! 


\section{Tleyde MPacédo Rodrigues}

Sobrinha, filha de Maria José (Mãe Zezé), viúva, tem quatro filhos.

Esta é nossa prima, no entanto, alguns de nós a chamamos de tia Cleyde, talvez pela diferença de idade. Tia Cleyde é sensacional! Transita muito bem por todas as "tribos". Bom papo, muito bem informada de tudo: política, mundo artístico, fofocas e por aí vai...

Sempre nos recebe com muito afeto e carinho na fazenda São João/Independência. Não foram poucas as vezes que lotamos o São João, na famosa Festa da Padroeira da cidade, Senhora S'antana. Movimento altíssimo que até hoje acontece. Uma idosa jovem!

Presenteou-me com estes memoráveis escritos de sua filha e nossa inesquecível prima Ana Cleyde (Naquede) in memoriam, que nos alegra profundamente, com suas manifestações por estes registros, de tão grande afeto pela Fazenda Lagoa das Pedras e que, com certeza, vem para abrilhantar os Contos da Lagoa. Emocionei-me por várias vezes ao transcrever seus registros. Gratidão e Saudades!

\subsection{Lagoa Encantada das Pedras, energia em movimento}

Eu nunca pensei que, passados tantos anos, distanciando-me da infância, adolescência, juventude, pudesse com tanta clareza rever lugares, pessoas, coisas, acontecimentos, sentimentos.

Acho que nada acontece por coincidência. Estive no lugar certo, no tempo certo. Sentia tudo intensamente, viria ao lugar, mas só sei disso hoje. Parece que estava dormindo durante quarenta anos. Agora, sei porque sempre gostei tanto de lá, assim como sei o motivo de todos que por lá chegam e gostam tanto, até os dias de hoje.

A energia de lá deixa a gente voando como borboletas. A natureza, com toda a sua beleza junto com o amor que sempre foi vivido, doado, exercitado, continua 
presente da terra ao magnífico céu, do qual agora revejo no meu pensamento. Nada maculou aquele universo, tudo bem preservado.

Hoje, entendo porque chorava dias a fio, quando vinha embora. Eu me sentia arrancada de lá, me doía tanto! A sensação é como se eu estivesse voltando para um mundo do qual eu não pertencia, tanto era a minha identificação com aquele universo.

Hoje, sei que a gente tem que ligar a própria energia quando sai de um lugar fantástico, como a Lagoa das Pedras, parecia que minha alma lá ficava durante um bom tempo. Era um choque muito grande, quase três meses, respirando, tocando, sentindo a beleza e grandeza da natureza, tudo isso misturado às brincadeiras, ao riso, à alegria, à liberdade, ao amor. Hoje, sinto que mesmo meninos, éramos respeitados, como também colocados no devido lugar, se assim fosse preciso. Mas, não éramos apenas "meninos do buchão", e nem adolescentes desvirados e, sim, pessoas, ainda que pequenas, respeitadas.

Ainda não consigo entender porque armazenei tantas coisas boas, mas tantas... e nem lutando consegui fazer o uso delas quando comecei a escolher meus caminhos. Ai! Passou... (mas essa é a única "estória") que não vou contar. Depois de um longo tempo, estive lá no ano passado. Intuitivamente, entreguei-me à magia do lugar, não mais chorei, só me alegrei, a cada minuto, cada hora, cada dia. E, dessa vez, preparei-me para atravessar "o Rio", foi a primeira vez que saí sem ter medo de voltar para esse mundo. “Que louca!”

\subsection{A viagem}

Estamos nos anos de 1963, acho que o ano da primeira vez que viajei até a Lagoa Encantada das Pedras. No meu mundo mágico, aquele trajeto da estrada vicinal, tortuosa, cheia de grotinhas, pedrinhas, riachos, animais, foi uma verdadeira aventura ao desconhecido. Não me importei se viajamos demais, se o dia foi ficando para trás, tal a alegria da minha pequena alma romântica e sonhadora. E assim foi por todos os anos seguidos, quando lá voltei. 
De fato, a viagem começava para mim quando deixava Coronel Jiló para trás, quando o caminhão, o misto, ou o carro do tio Manoelzinho saía do Seu João Lima, com toda a notinha (grande!) da tia Estrelinha comprada; começava a aventura. Não sabia que hora chegaria, mas isso não importava. Nada era incômodo, pois eu estava cheia de alegria para mais uma aventura.

Pela estradinha velha, seguíamos, às vezes, em volta de muita poeira, às vezes, pelos caminhos molhados, ladeados por moitas de verde sem igual! Muitas vezes, vi o pôr do sol. A tarde caía morninha, trazendo a frieza da noite, o céu pontilhado de estrelas se destacando na escuridão. Viajamos à luz da lua que prateava fortemente os trechos de areia alvinha da antiga estradinha. Era tudo que eu queria para o meu reino encantado, perfume de cheiro, ilusão!

Cada viagem era única, nada se repetia, o caminho, a paisagem, o tempo, o sol, o cheiro sentido da terra seca, da chuva, das águas que rolavam pelas pedras esbranquiçadas, do vento que se intensificara quando atravessávamos descampados, tudo era diferente; nem minha emoção era a mesma, já que cada viagem (de ida), ela crescia, o que me possibilitava sentir com maior intensidade tudo que o carro ia engolindo pela estrada a dentro. Para os adultos, viajamos da civilização para um centro, para mim, era o contrário, quanto mais eu mergulhava pelo sertão, mais e mais eu ia chegando para o maior lugar, até hoje dentro do meu coração. Assim, por muitos anos, vivi intensamente cada uma dessas viagens com gosto de fantasia, de magia, mas tudo acontecendo num mundo muito real. Ah! Como era confortável ir encontrar com esse mundo!

Companhia afável do tio Manoelzinho; ele procurava tornar a viagem o melhor possível, ajeitava o lugar em que nos sentiríamos bem. Sempre estou plural, mas é que essas viagens muitas eram as personagens, a merendinha no meio do caminho, a calma, se por ventura a noite nos pegasse em um "prego", a própria hora da viagem para aqueles dias tão tranquilos, era maravilhosa.

O tempo foi passando, a estradinha com todo o seu encanto foi ficando para trás, e uma grande estrada a rasgar a terra, transformando aos poucos o que chamamos de Centrão. As viagens foram se modificando, assim como cada um de nós. Nessa 
época, minha visão do mundo, meus sentimentos cresciam junto com a alegria e o amor com que sempre fiz a viagem de ida.

No ano passado, depois de tanto tempo, a viagem de ida e volta foi um contentamento só! Céu nublado, chuva, cheiro de mato, terra molhada. Aos poucos, fui chegando à beira do "Rio", onde fica o portal dessa dimensão, onde a felicidade é incondicional para todos que chegam, e que, de um certo modo, eu ficarei ali para sempre.

\subsection{A casa}

Cada vez que fecho os olhos, a visão de tudo o que revejo me aquece a alma. A chegada depois da viagem mágica, fantástica, era sempre uma festa! O coração pulava de contentamento, enquanto começava adentrar a casa. Enfim, o contente, o alegre, o livre, o amor chegaram novamente em mim, por aquela bênção e daquele abraço forte apertado dado pela tia Estrelinha.

Naqueles momentos de chegada, sempre havia muita agitação na casa, a grande bagagem que vinha da cidade a ser descarregada, ao jantar para ser servido, ir ao encontro dos primos (no começo, tudo timidamente) e dos que lá moravam e nos cuidavam; eram muitos abraços, muita movimentação.

Excitação até que nos deitássemos. E o melhor sono do mundo tomava conta do meu pequeno ser deslumbrado pela fantasia de estar novamente no castelo dos meus sonhos infantojuvenis.

A casa acordava cedo, com toda a energia e a pulsação voltadas para o laboro fazendário. Eu ficava ouvindo a vida da casa. Tudo começava com um canto do galo no quintal, e que era respondido ao longe, intercaladamente por outros cantos... 


\section{Matheus Qancho QBelmino}

Neto por afinidade, administrador e corretor de imóveis, noivo da Camilla.

\subsection{Minha rede e as selas de montaria}

Minha sogra, tia Aurélia (como carinhosamente a chamo), adora fazer uma programação para estar junto à família. É invenção de todo jeito, e em uma dessas programações, tive a primeira oportunidade de estar na Fazenda Lagoa das Pedras. Soube que foi um mês de movimentação altíssima para minha ida.

Ela sempre deixou bem claro que o sertão é para quem gosta: se eu gosto, vou gostar, simples assim! Vamos ter o que o sertão tem a oferecer. Não tem como ser diferente, é como você ir para o frio e querer hábitos de um lugar quente e vice-versa.

No meu caso, sou "passado na casca do alho". Quando criança, passava dias, como até hoje passamos na Fazenda Alegre, que fica em Tejuçuoca, perto de Irauçuba, lugar "friiio". É a fazenda do meu saudoso avô Afonso Sancho, que por sinal, Camilla sempre me falou que lembra muito a Lagoa das Pedras. Então, sou totalmente adaptado ao sertão e aos costumes de lá.

Antes da viagem, tia Aurélia, já ia me deixando a par de alguns costumes e tradições da fazenda, como também falava de algumas figurinhas carimbadas (pessoas interessantes) de lá, como querendo já me colocar no clima do lugar. Então, depois de um mês falando na ida para a fazenda, lá vamos nós!

"Ô bar longe", como se diz! Chegar já foi uma das alegrias. Realmente, muito semelhante à fazenda Alegre, os caminhos, as pessoas, a própria casa. Quando chegamos, ainda abrindo a porteira, já vimos de longe minha querida sogra pulando e balançando os braços, nada ansiosa, para não falar o contrário. Mal estacionamos, nem desci do carro, ela já disparou a pergunta: “Primeira impressão?!”. Ri e pedi para esticar as pernas antes (risos!). Passamos o resto do dia naquele movimento, conhecendo a casa, sendo apresentado a "Deus e ao mundo", e no trajeto Lagoa das 
Pedras - Mucunã, rancho construído por ela e meu sogro, que também tive a oportunidade de conhecer nessa viagem.

Como o Rancho fica fechado por meses, sempre que ela chega, é necessário fazer uma faxina, então dormimos na casa da Lagoa. Percebi que na Lagoa das Pedras existe o "bê-á-bá" das dormidas, aquele "frejo" (animação) de quem vai dormir onde. É quase um quebra-cabeça, mas, no fim, dá tudo certo. Tia Dalva, naquele para lá e para cá, sempre querendo nos proporcionar o melhor. Gente boa! O detalhe é que nessa ida, diferente do normal, só tínhamos nós na casa, eu, Camilla, tia Aurélia, tia Dalva e Hortêncya, a qual tinha ido com a gente. Então, aparentemente, tinha lugar de sobra.

Tia Aurélia disse que tinha separado a melhor dormida da casa para mim. Pegou uma rede e foi... me animei. Ela armou minha rede na varanda (eles chamam assim, mas é um quarto sem camas, com vários armadores e onde guardam as selas de montaria), colada na parede, do lado do cavalete onde colocam as selas. Não dava para me balançar, a qualquer movimento, batia nelas.

Ok! Me deitei na rede, que era tão funda que não alcançava os punhos, e enrolei o lençol no rosto, para não ficar olhando para as fotos nas paredes, isso porque já tinham me falado que, daquelas fotos, quase ninguém mais era vivo, então preferi assim para evitar a fadiga (risos!). Até tirei o lençol uma hora para procurar o celular, mas tive a impressão de continuar com os olhos fechados de tão escuro (risos!). Camilla e Hortêncya continuaram conversando nas redes ao lado, e durante essa conversa, a janela abriu com o vento. Elas começaram a chamar por mim, com medo de fechar, mas é claro que eu não iria me levantar nunca, naquela escuridão, então elas deram um jeito.

No dia seguinte, fui comentar com minha sogra em tom irônico que meu prestígio com ela estava grande, me referindo à minha dormida. Ela me respondeu o seguinte: "meu filho, você tá é por fora, aquele lugarzinho ali é um dos mais disputados, porque fica fora da passagem, e você não seria acordado tão cedo, foi por isso que coloquei você lá, você é um privilegiado!". 
Brincadeiras e reclamações (como um bom genro faz - risos!) à parte, foram três dias ótimos, estar no sertão me faz muito bem e foi uma honra conhecer a Fazenda Lagoa das Pedras, com muitas gargalhadas e um bom papo. Depois da primeira vez, outras muitas vieram, e hoje me sinto em casa por lá também! 


\section{Ana Izabel Foutinho Taswalho o Rodrigues}

Filha, assistente social, nascida na Lagoa das Pedras, casada com Helder, tem três filhos: Victor Manuel, Cândida Mayara e João Felipe.

\subsection{Lagoa das Pedras: o meu lugar do mundo}

De maneira muito especial, quero agradecer e parabenizar a Lelinha, nossa caçulinha, pela bela iniciativa e incentivo para esta produção. Certamente, irá proporcionar às nossas futuras gerações conhecerem um pouco da linda história dos Coutinhos/Carvalhos.

Logo que recebemos o convite para a construção desta resenha sobre nossas memórias afetivas, vivenciadas na Lagoa das Pedras, minha mente transbordou de tantas recordações fecundas e maravilhosas. Posso afirmar que nenhuma lembrança que me veio, sequer, foi melancólica. Todas elas me fizeram reportar a fases encantadoras de minha vida na Lagoa das Pedras, aliás, para não dizer que não tinha nenhuma lembrança meio tristonha, me recordo agora, que não era nada agradável saber que já estava se aproximando o dia de voltar para Crateús e retornar às aulas.

A tia Ludugera, mulher do Didilo e mãe da Ana Cristina, preparava nossas roupas para a viagem, de forma muito discreta para a tristeza não bater muito cedo. Às vezes, até chorava, mas papai e mamãe nos sensibilizavam com a sabedoria e prudência que lhes eram muito peculiares, que o maior patrimônio que poderiam nos deixar seria o estudo, o conhecimento, e que na fazenda não seria possível. Mas, por mim, ficaria por lá mesmo, estudando nas escolinhas em que minhas amigas estudavam.

A gente ia para a cidade, mas ficava contando os dias para voltar. A saudade era grande de tudo e de todos. Nossa amada tia Ferreira, que apesar da idade avançada e da cabecinha já branca, dizia: “Chore não, minha filha, você vai estudar pra ser doutora, pra comprar um carro pra gente passear". 
Nossos pais nos ensinavam a lidar de forma muito respeitosa com as pessoas, em especial, com os idosos, e nos ensinavam a chamá-los de tio ou tia, "padrim" ou madrinha, tornando, assim, uma grande família, onde reinavam sempre o acolhimento, o respeito, sem imposições... Às vezes, não era fácil para uma criança entender, como o tio Ferreira, tão pretinho, seria nosso tio, mas só em pensamentos... quem teria a indelicadeza de perguntar o porquê?! O mesmo acontecia com nossos irmãos mais velhos que apadrinhavam os mais novos, e por tabela, crescia sua autonomia sobre nós.

Sempre que chego à Lagoa, meu primeiro lar, fico num verdadeiro estado de graça. Que lugar abençoado!

Nasci na Fazenda Lagoa das Pedras, no dia 30 de dezembro de 1959. A mamãe tinha quase 38 anos, eu seria a nona filha. Ela contava que foi um período de grande inverno e que o Poty transbordava. Considerando, talvez, sua idade, foi um trabalho de parto muito prolongado, havendo a necessidade de chamar o médico. A parteira não daria conta. Destarte, foi necessária a vinda do Dr. Olavo Frota, de Crateús à Lagoa das Pedras.

Ocasião em que o Rio Poti estava cheio e o médico precisou atravessar numa balsa. Dizem que o Dr. gostava muito de pássaros, e que ele havia levado uma gaiola com a intenção de pagar alguns bichinhos durante sua permanência na fazenda. Durante o trabalho de parto é de costume acender incensos, alfazema para perfumar o enxoval do bebê. Então exalava um aroma de alfazema por toda a casa. Foi armada a melhor rede branca na varanda para que o médico pudesse repousar um pouco após a viagem que, à época, era longa e cansativa, devido à estrada e aos grandes atoleiros. Após algumas horas, eu vim ao mundo, linda, maravilhosa, graças a Deus! Meu nome Ana é em devoção à Senhora Sant'Ana, padroeira de Independência, município em que à época a Lagoa das Pedras pertencia e Izabel, em homenagem à Bebela, irmã do papai.

Minha primeira infância, especialmente até meus cinco anos, foi integralmente na Lagoa das Pedras. Nessa época, moravam muitas pessoas lá em casa e era grande a movimentação, com grande fluxo de pessoas que tinham negócios com o papai, dos mais diversos segmentos: comerciais, familiares, políticos, dentre outros, 
além das pessoas com outros objetivos, que por lá circulavam. Quase diariamente, uma média de 25 pessoas almoçava lá em casa. Havia uma movimentação muito intensa durante o dia, em especial quando a "junta" de trabalhadores, na época do plantio e da colheita.

A religiosidade também se fazia muito presente em nossas vidas e formação. O terço era rezado diariamente, após o jantar, e o serviço de cozinha ser encerrado para possibilitar a participação de todos. Nos meses dos santos de devoção, como Senhora Sant'Ana, Nossa Senhora de Fátima, São Francisco, São Sebastião, dentre outros, se rezava o novenário.

Foi uma fase da minha vida de muitos encantos, em que tudo era em clima de festa... não havia tristeza... Qualquer probleminha de saúde, nada que um pouco de repouso, guaraná ou chá com bolacha, um remedinho caseiro ou uma reza não resolvesse. Tudo muito natural.

$\mathrm{Eu}$ tinha muitas amiguinhas e as brincadeiras eram as mais variadas e divertidas... brincar de fazer comidinhas debaixo das árvores, inclusive o Toidantas ou o Didilo, não lembro bem, fez uma casinha linda de barro com porta e janela, coberta de folhagem para a gente brincar... pena que, naquela época, não tinha a facilidade de fazer fotos para a gente ter mais lembranças. "Pega pega" no terreiro em noites de luar, passar o anel, passear nas casas dos moradores, pular corda, tomar banho de açude, grota e rio, onde aprendi a nadar, brincar trepada no umbuzeiro, cada um tinha sua galha. Árvore linda e frondosa, ainda hoje; plantada pela Bebela há quase 100 anos, uma das duas irmãs do papai que conheci ainda criança. Tinha também a brincadeira de subir e escalar pedras de grande porte. Verdadeiros desafios! Era bom demais! Mas aí, a Lelinha e outras amigas sempre levavam vantagens. Era difícil eu chegar aonde elas conseguiam...

Lembro-me demais que, na época de eleição, resolvemos fazer a nossa. Duas candidaturas: Ana Izabel para prefeita e Clarice para vice. Aurélia para prefeita e Elvira para vice. As candidatas à vice também eram irmãs e filhas da madrinha Fransquinha e "padrim" Alfredo, nosso parente e vaqueiro da fazenda. Os eleitores eram os moradores da Lagoa e também os transeuntes... a gente ficava de plantão na calçada e corria para abordar quem passava no terreiro e pedir voto. 
Meu cabo eleitoral era muito atuante... Resultado: ganhei com maioria absoluta! E a Lelinha não se conformava. Houve muito "chororô". A Lelinha e a Elvira não se conformavam. Daí a mamãe proibiu a brincadeira dizendo que havia outras bem melhores.

É muito comum o sertanejo fazer comparações de características de pessoas com animais. Quando era época de ensacar e pesar legumes, milho, feijão, algodão, nós, crianças, adorávamos pedir para nos pesar. Eu era gordinha, pesando sempre acima de $30 \mathrm{~kg}$ e a Lelinha nunca passava de 25. Quem relembrou recentemente essa história foi o personagem principal, Domingo Selvinho, piauiense que trabalhou muito tempo lá em casa, irmão da Betinha e Zulmira que chegaram ainda bem jovens lá em casa. Com muita graça, ele contou que, quando a Lela perguntava, ele dizia que o peso dela era igual ao de bode.... nunca passava de $25 \mathrm{~kg}$. Motivo para ela ir chorando dizer para a mamãe. Reservadamente, mamãe recomendava que ele aumentasse o peso e não fizesse a comparação para a Lelinha não se contrariar. E, assim, ele fazia. Pouco tempo depois, ela se pesava e já estava com 5 ou mais quilos de peso, deixando-a muito realizada, quando sabia que estava pesando mais do que eu.

A chegada do papai de viagem na picape verde-escura era sempre de muita alegria e expectativas, porque ele sempre trazia umas novidades da cidade... bombons, biscoitos recheados, doce em lata (abacaxi em calda, banana, goiabada), porque eram mais comuns os doces caseiros de leite, banana, feitos lá mesmo. Quando buzinava para abrir a porteira, todo mundo corria para a calçada para ver a chegada. O papai não dirigia. Sempre teve motoristas que, por sinal, despertavam paqueras com as jovens que trabalhavam lá em casa. Logo, eram rapazes mais modernos, da cidade.

O período de férias era uma festa para mim, talvez, o mais marcante! Principalmente quando estavam os primos e as primas de Fortaleza. Galera de adolescentes e adultos jovens, o que despertava paqueras e paixões. Achava o máximo, os primos da capital. E um deles, em especial, despertou-me para os encantos do amor e da paixão. Isso mesmo, ainda na adolescência, já despontou meu sentimento de admiração, paixão por um gato de olhos claros, charmoso e que cantava e falava inglês, de um “olhar 43" irresistível. Ele mesmo, o Heldim! Então foi uma fase inesquecível, porque aí, teve início a minha linda história de amor: namoro, noivado e casamento 
com o primo Helder, resultando em nossa preciosa família, Carvalho Rodrigues; Helder e Ana, Victor Manuel, Cândida Mayara e João Felipe... Nosso porto seguro e o bálsamo de minha vida.

São muitas as recordações que vão aflorando a cada dia... mas ficarão para a próxima...

Gratidão a Deus por tudo, por meus pais, Manoel Carvalho e Maria Estrela, fonte de tudo que sou e somos! 


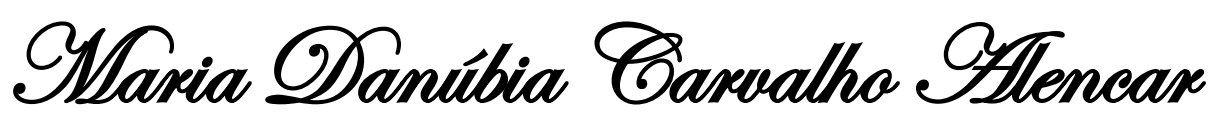

Filha, professora, nascida em Crateús, casada com Ossian Alencar, tem cinco filhos e seis netos: Isaac, Letícia, Beatriz, Arthur, Marina, Joana e Malu (Maria Luísa).

Lagoa das Pedras onde nos viu crescer.

Alvorada iluminada que nos despertava.

Gostoso lar que nos formava com humildade para voar.

Os nossos pais, tios e moradores nos amavam e respeitavam.

Alegria minha e dos manos neste aberto sacrário.

Durante as férias, mesmo verão, para nós, era primavera.

As flores rústicas, pássaros, rios e aves da caatinga nos encantavam.

Sonhar, brincar, rezar e trabalhar eram, para nós, festa.

Pôr em prática os ensinamentos maternos era lei.

Educando, adorando a Santíssima Trindade e amando ao próximo como a nós mesmos.

Demonstrando amizade, caridade e aconchego.

Respeitando as diferenças e os limites dos mais simples.

Adotando-os, habitualmente, como padrinhos e madrinhas.

Senhor e Senhora, tratávamos assim, os mais velhos com carinho. 


\section{Uma homenagem às minhas tias Aiá e Bebela}

Suas frases e músicas que ficaram gravadas em minha memória.

“Vi seu rastro na areia, me pus a imaginar, era o rastro do mambira ou do bicho Tamanduá" (Aiá).

“Mundo que já foi mundo, mundo que já não é, mundo que já virou cabeça para os pés" (Aiá).

"Ainda vamos ver a roda grande entrar dentro da roda pequena" (Bebela).

"Quem me quer bem e busca, quem foge tem queixa" (Aiá).

“Eu só quero quem me quer!” (Aiá)

“De onde vem e pra onde vai?" (Bebela)

"A cor morena é cor de prata, a cor morena é que me mata" (Aiá).

“E do meu gosto é da minha opinião, de amar a cor morena com prazer no coração. (Bebela)"

“Adoremos, adoremos ao Coração de Jesus, com Ele aos Céus iremos cercado de muita luz." (Bebela cantava).

"Anda Luzia traz o pandeiro e cai no carnaval, anda Luzia que esta tristeza faz mal" (Bebela cantava).

“Fui um forró lá em Baturité e um cabra pisou no meu pé".

\section{Aiá, fazendo referência ao estado do Piauí como um lugar bom.}

Quando alguém dizia com pronúncia do sertão que ia para o "Pioir", ela dizia: "pior não, mior ir. Pioir $=$ pior ir e Mior $=$ mior ir" .

\subsection{A netinha caçula}

Aos três meses de idade, fomos levar Camilla para Dona Estrelinha conhecer a neta. Lembro-me como se fosse hoje, eu, Lelinha e Dalvinha. Saímos bem cedinho, por orientação da Dalvinha, já que íamos com um bebê de colo. 
Dona Estrelinha nos esperava ansiosamente. Naquela época, a viagem durava umas 6 horas, pois tinha a parada em Crateús para passar na casa dos familiares e para um ligeiro descanso. Chegamos para o almoço. A chegada sempre era um alívio para quem estava esperando, tendo em vista a preocupação com as estradas. Dona Estrelinha ficou muito feliz com a chegada da filha com a neta. Achou Camilla muito bonita e, realmente, era. Recomendou para que Lelinha não mostrasse a menina a todo mundo, pois acreditava ela que podiam colocar quebranto. Quando alguém chegava para ver Camilla, ela dizia que a menina estava dormindo.

Nessa época, Dona Maria José estava passando uma temporada lá. Como era de costume, uma tardinha, estávamos sentados na calçada, em um grande banco de madeira encostado na parede, logo na saída da porta principal, um horário em que todos costumavam vir para a calçada. Cheguei com Camilinha nos braços; Dona Estrelinha cochichava, quando Dona Mazé me disse: “Augusto, menino! Se você tivesse que negar que essa menina não era sua filha, não tinha como, pois ela é sua cara!" Todos riram, mas confirmando o que ela tinha dito.

Nunca me esqueço disso e, realmente, até hoje as pessoas acham Camilla muito parecida comigo. Foram uns dias maravilhosos, todas as viagens para a Lagoa das Pedras tinham "estórias" peculiares.

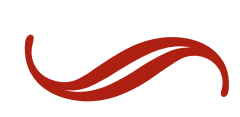




\section{Barlas Arugusta OBota Oimplicia}

Genro, administrador de empresas, casado com Aurélia.

\subsection{Rancho Mucunã}

Em setembro de 2014, na localidade de Jatobá, município de Quiterianópolis, a caminho da Fazenda Lagoa das Pedras, escapei por um milagre, de um acidente em um Jeep TR4. Foi nesse momento que pensei, puxa vida! Quase morri e não construí nenhuma casa na Lagoa das Pedras, pois sempre pensei em ter um espaço para minha família, apesar de sempre ter sido muito bem acolhido na casa sede, porém, com o tempo o ideal é que cada um tenha seu lugarzinho.

$\mathrm{O}$ carro ficou bem estragado. Antes do acidente, valia trinta mil reais, mas ainda consegui vender para uma sucata por dez mil e reservei esse dinheiro para iniciar a construção desse sonho. O lugar da construção foi o lugarejo da fazenda, chamado Mucunã. Na realidade, lá já existia uma casinha que Seu Manoelzinho havia construído para os moradores, mas era muita baixa, quente e pequena. Precisava de uma grande reforma: altear, construir uma cozinha, mais um quarto, mudar toda a planta, além do alpendre para proporcionar mais conforto.

Na época, muitos, até mesmo a Lelinha, não via sentido naquilo, achavam uma loucura! Carvalho dizia: "ele tá ficando completamente doido", "rapaz pega seu dinheiro e empregue em noutra coisa".

Quando comecei a carregar os troncos da algaroba velha que haviam sido cortados da casa da fazenda, já pensando em utilizá-los para as colunas do alpendre da cozinha, foi então que Carvalho entendeu que estava convicto do que queria e, a partir daí, passou a me ajudar, inclusive o Toinho (Antônio Luiz). Os dois tomaram gosto, algumas vezes, até colocando a mão na massa e facilitando no que era possível e nos incentivando.

Lelinha tomou gosto e passou a abraçar o projeto como seu e, finalmente, a família percebeu que não era tanta loucura assim, passando também a ser mão de obra. 
Antonino chegou a me dar uma casa velha na Carnaúba, para que demolisse e usasse os tijolos.

A construção durou um ano e meio, não havia urgência. Ao concluir, oferecemos um jantar, no dia 16 de janeiro de 2016, que foi chamado "Jantar dos Moradores", pois os convidados de honra eram todas aquelas pessoas que trabalharam na construção do rancho e os moradores das fazendas Lagoa das Pedras, São Jerônimo e Guaribas. Eram, em média, duzentas pessoas.

Jantar organizado e produzido por Lelinha, com a ajuda da família, com muito capricho! Foram contratados profissionais para fazer e servir o jantar, estilo buffet. Haviam colocado mesas com lembrancinhas para os convidados, fogos de artifício e tudo como manda o figurino.

Houve o momento das falas, onde expressamos a felicidade daquele instante e agradecemos a Deus e a todos. O momento mais emocionante foi quando foi passado no terreiro, em um grande telão, a história do casal Manoelzinho e Estrelinha, tronco da Família Carvalho. Foi um grande momento de silêncio! Muitos dos moradores mais velhos se emocionaram ao ver aquelas imagens.

Os moradores se sentiram muito prestigiados, pois perceberam que tudo foi feito de forma muito especial para eles. Toda a família fez questão de servi-los em suas mesas, pois, logo, entenderam a ideia daquele evento. Percebiam-se a alegria e a gratidão dos convidados pela forma que foram acolhidos e tratados.

Também foi realizado, naquele local, o Natal das crianças, com a presença do Menino Jesus, uma peça teatral do nascimento de Jesus e a entrada triunfante do Papai Noel, representado por mim, numa carroça puxada pelo burro Canário.

No terreiro, um parque de diversão para as crianças, pipoqueiro, algodãodoce, refrigerante, cachorro quente, pastel e um bolo de um metro que foi compartilhado com todos os presentes. Houve ainda a entrega de 120 presentes e o sorteio de uma bicicleta. Estima-se que havia duzentas pessoas entre crianças e adultos.

Já a festa de São João teve sanfoneiro, quadrilha, casamento matuto e comidas juninas. O forró pé de serra foi até às quatro da manhã. 
O Rancho Mucunã é um lugar aconchegante e charmoso, com uma natureza exuberante. A decoração é rústica e histórica (objetos da Família Carvalho), de muito bom gosto, imaginada e produzida pela habilidade decorativa da Lelinha.

Tornou-se mais lugar de diversão para a Família Carvalho. Um local democrático que está e estará sempre de braços abertos para todos que ali chegarem. “Filho de peixinho, peixinho é!” Lelinha costuma dizer que o Rancho Mucunã já é filho (fruto) da Fazenda Lagoa das Pedras.

Portanto, a Fazenda Lagoa das Pedras de hoje é um grande complexo, pois além da casa sede (fazenda), que já é uma atração por si só, tem o Rancho Mucunã, a Carnaúba I do João de Deus e a Carnaúba II do Antonino, casas que só agregam e trazem benefícios para toda família. 
Foto 12 - Virgílio Carvalho Dantas - Nosso parente e morador mais antigo da Fazenda Lagoa das Pedras, desde 1957

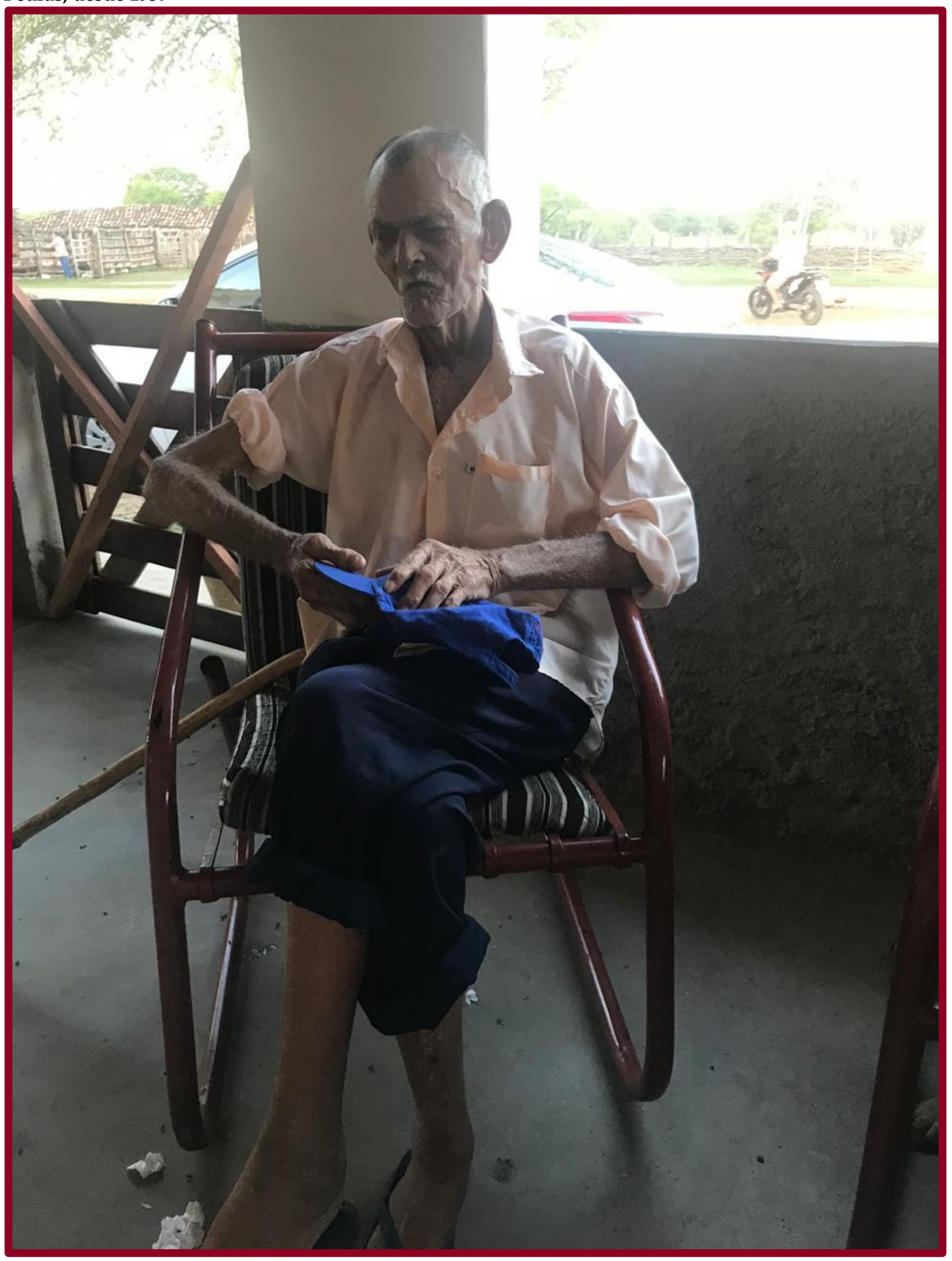

Fonte: Acervo da Família. 


\section{Henxique Mescandre Monte Gaxwaltho}

Neto, bacharel em sistemas de informação, filho de Antonino e Fátima, casado com Vanuza, tem duas filhas: Cecília e Laura.

\subsection{Meus passeios na fazenda}

Durante a infância e adolescência, minhas idas à Fazenda Lagoa das Pedras eram mais frequentes. Guardo boas lembranças da vovó Estrelinha, sempre atenciosa e caridosa. Do vovô Manoelzinho. Armazeno as boas "estórias" dele, que até são contadas pela família. Dentre suas qualidades, destacavam-se sua bondade e hospitalidade.

Recordo-me do jogo de bola em frente à casa da fazenda com os primos e os garotos que residiam lá e na vizinhança. Guardo também recordações do Xodó e Guaxinim: cavalos da fazenda, bonitos e velozes.

Seu Virgílio, Seu Martins e Seu Viana são personagens marcantes, pois, habitualmente, meu pai contava suas "estórias"; estavam sempre presentes na fazenda.

Em 1997, fomos a Quiterianópolis/CE e, na oportunidade, conhecemos o Davi, o primogênito do tio Carvalho e da tia Silvânia, que havia nascido há poucos meses. E, agora, é pai da pequena Luíza.

Na virada do ano 2000, estive presente na posse do tio Antônio Luiz como prefeito de Quiterianópolis. Num ginásio completamente lotado, ele preferiu um discurso acalorado para a população que lá se encontrava. Na ocasião, alguns de seus irmãos também fizeram uso da palavra, desejando-lhe uma gestão exitosa.

Minha última passagem na Fazenda Lagoa das Pedras foi em 2015. Desta vez, fomos até ao Piauí. Eu, meu pai e tio Carvalho. Lá, conheci as propriedades Várzea do Bessa e Vitória. Almoçamos um dia nos Tucuns, propriedade do tio Mourão. O feijão para o almoço foi colhido na roça, naquela mesma hora, almoço feito por Sebastião do Deuzim, acreditem! Ficou excelente! 
Visitamos Seu João Rita e a Senhora Da Paz, fomos muito bem recepcionados. Ela nos ofereceu chá e café nas xícaras que meu pai lhe havia dado de lembrança, fazendo questão de dizer e agradecer. Pessoas simples e acolhedoras.

Durante o percurso na estrada "carroçal" (carroçável), observei como a vida social do meio rural é intensa! À noite, os moradores se reúnem e colocam as cadeiras em frente as suas casas para contar "estórias". O homem do campo não é apenas mais um indivíduo, como costumeiramente é nas grandes cidades, ele tem identidade, nome e sobrenome e é conhecido e respeitado por todos. Apesar de uma vida simples, as pessoas são felizes, vivem em comunidade, se ajudando mutuamente, de forma solidária e harmoniosa. 


\section{Q Galenia: OPssoas}

Foto 13 - Família Carvalho (Pais com seus Dez Filhos)

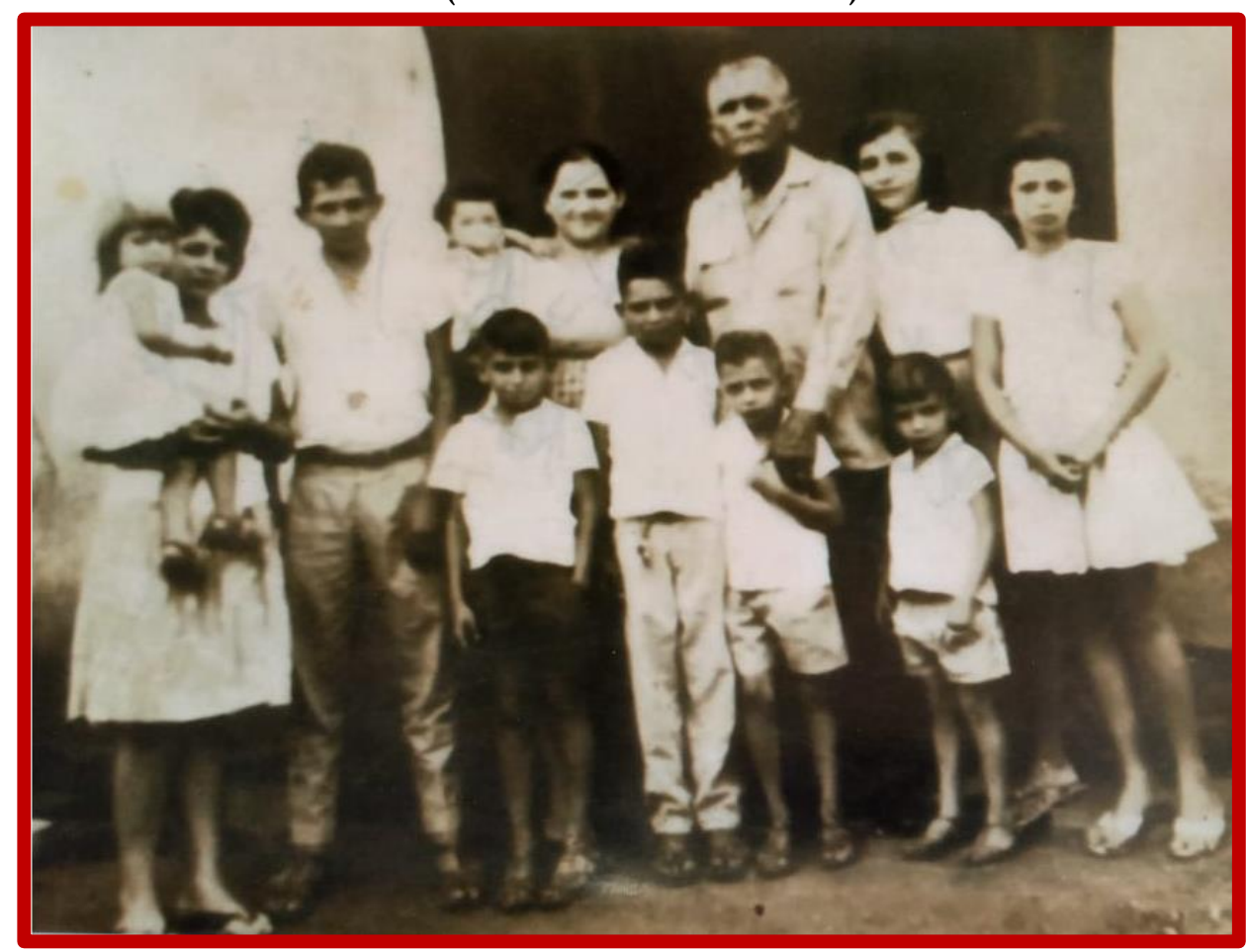

Fonte: Acervo da Família.

Foto 14 - Os Nove Irmãos (Da Direita para a Esquerda: Antonino, Danúbia, João de Deus, Ana Izabel, Lucimar, Antonio Luiz, Aurélia Estela, Manoel Carvalho e Dalva)

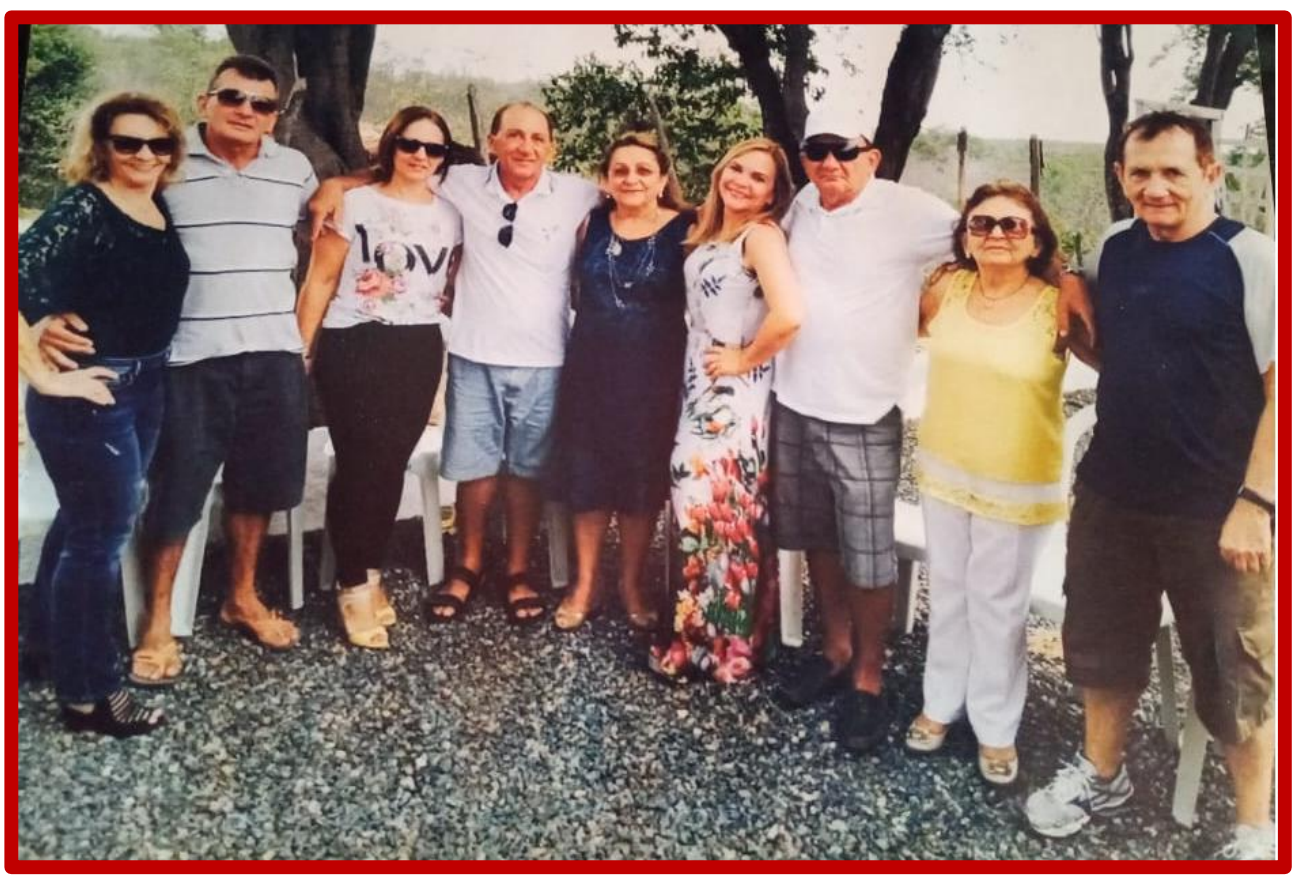

Fonte: Acervo da Família. 


\section{Q Galeria: OPssoas}

Foto 15 - Vaqueiro Rayone (Neto de Virgílio)

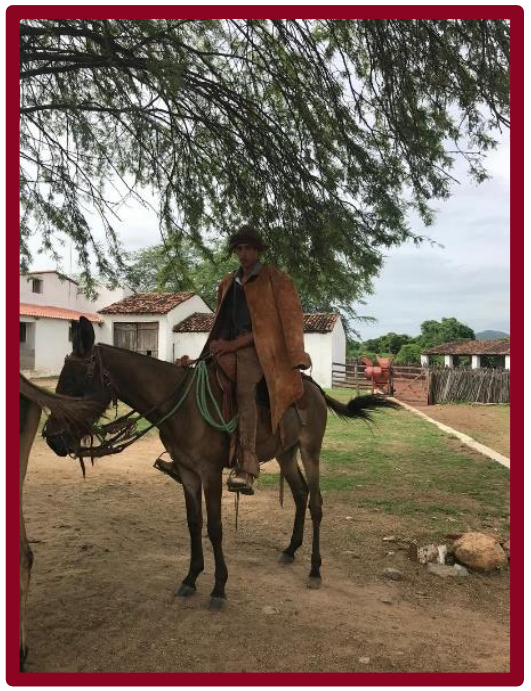

Fonte: Acervo da Família.
Foto 16 - Vaqueiro Leoney e Filho

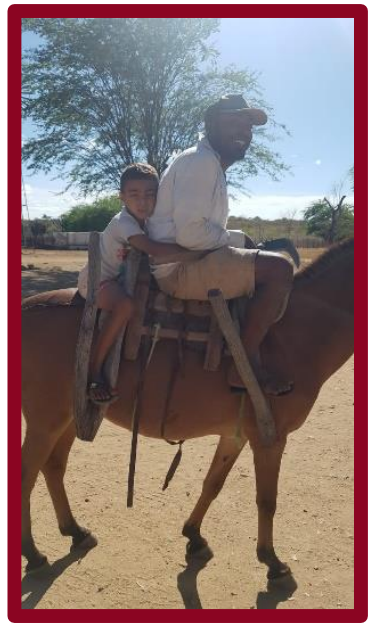

Fonte: Acervo da Família.
Foto 17 - Irmãos no Rancho Mucunã

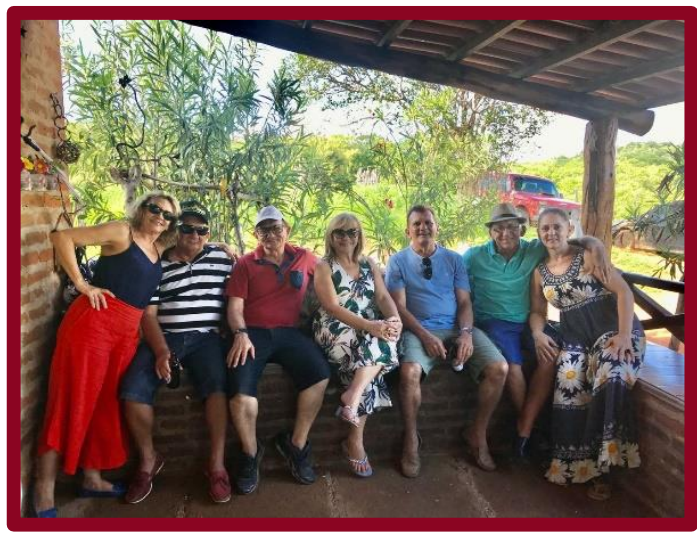

Fonte: Acervo da Família.
Foto 18 - Encontro da Família Carvalho

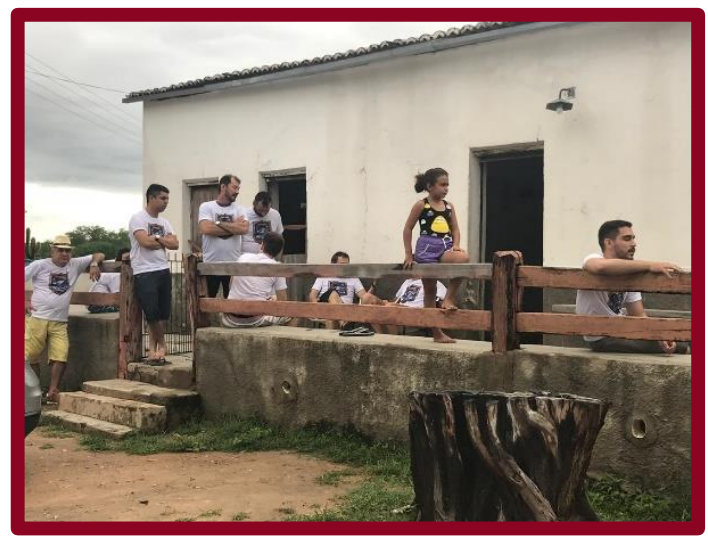

Fonte: Acervo da Família.

Foto 19 - Martin Tenente

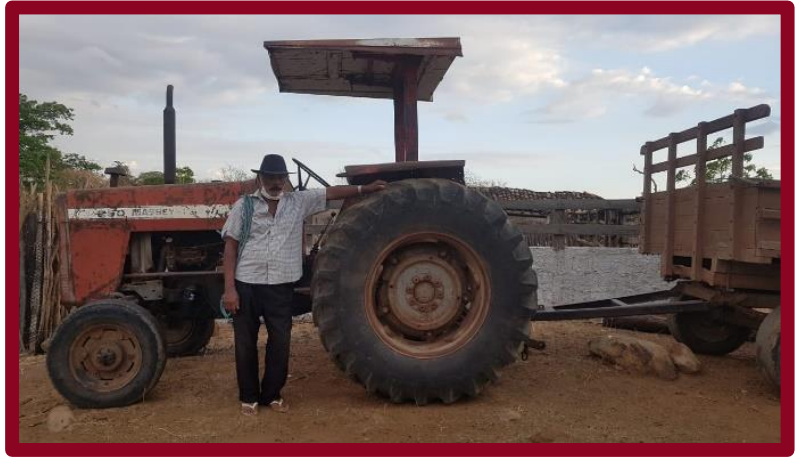

Fonte: Acervo da Família. 


\section{Manoed Wreiva de Garvalho Tritho}

Filho, engenheiro agrônomo, agropecuarista, casado com Silvania Medeiros Carvalho, tem dois filhos: Davi e Isabel, e uma neta chamada Luíza.

\subsection{Travessuras de criança}

Meu pai era um artesão nato, fazia da sandália de couro ao rabicho para animais. Quando ele queria produzir uma maior quantidade de coisas, mandava chamar seus compadres que tinham a mesma habilidade. Estava ele e seus compadres trabalhando para consertar umas cancelas e fazendo uns arreios de animais em geral, quando faltou prego; ele me chamou e mandou que fosse ao comércio do Seu Bentinho, comerciante da beira do rio, conhecido por todos, e disse: "diga pra ele que me mande uma caixa de prego". E assim, lá fui eu.

Já era quase final de inverno, mas o rio ainda tinha muita água escorrendo, o poço da ponte estava cheio, ideal para nossos banhos, cheio de aventuras! A maior diversão era pular dos galhos das árvores.

Ao chegar ao rio que era passagem obrigatória para meu destino, vi meus colegas pulando dos galhos, aí, não tive dúvida, tirei o calção e foi aquela diversão! Esqueci totalmente do meu compromisso com o papai. Nossa brincadeira, pulando dos galhos das árvores no leito do rio, nunca tinha hora para acabar.

Papai achando estranho o fato de eu não chegar, mandou alguém ir ver o que estava acontecendo e o porquê da minha demora. Certamente, a pessoa viu a nossa brincadeira e avisou para ele.

Percebi um grande silêncio dos meninos... era papai que tinha chegado e estava debaixo do grande pé de oiticica em que estávamos; mandou que eu descesse e fomos para casa. No caminho, o silêncio foi profundo, quase não chegava mais e olhe que era bem pertinho.

Ao chegarmos a casa, meu pai me deu um sermão, mostrando como eu tinha atrapalhado o seu trabalho e me deu uma lapada com o chicote, já conhecido de 
todos nós. Não sei se a "Lei de Chico de Brito" é correta ou não, só sei que para mim funcionou, nunca mais fiz aquilo. Até hoje, não esqueço dos ensinamentos de meu pai. Mas ele era tão bondoso que depois sempre dava um jeito de se aproximar, mantendo, assim, o respeito e a nossa amizade.

\subsection{Pedido de um filho}

Era mais uma linda noite estrelada; estávamos todos na calçada palestrando, como era de costume. Neste dia, papai tinha tido alguns problemas para resolver. Normalíssimo, para quem tinha algumas fazendas para administrar. Mas, naquele dia específico, ele estava muito cansado e nos disse que iria vender todas as fazendas, porque só lhe davam aborrecimento.

$\mathrm{Eu}$, ouvindo a conversa, deitado no colo da mamãe, pois, nesse dia, tinha sido premiado. A sorte é que era o caçulinha homem. E, ouvindo aquela conversa, imediatamente falei: "papai, vou lhe pedir uma coisa ao Senhor: pode vender todas as fazendas, mas não venda a Lagoa das Pedras". Mãe Zezé, que estava presente, achou muito interessante essa minha intervenção e como sempre gostava de opinar, disse: “Manoelzinho, você precisa atender o pedido do seu filho". Nunca esqueci isso!

Passados aquele cansaço e o aborrecimento, nunca mais ele falou em vender fazenda e foi isso que aconteceu e, por incrível que pareça, hoje a Fazenda Lagoa das Pedras é meu segundo lar.

\subsection{Fazendo arte nas melancias}

O Senhor Antônio Romano era um negro africano, com certeza, ainda tinha hábitos da escravidão, nos chamava de "Sinozim". Morador da época do papai, sua roça era uma maravilha, tinha o que mais a gente gostava: melancias. Era cada melancia!

$\mathrm{Eu}$ e meus colegas passávamos à tarde toda na roça dele, comendo melancia, isso era habitual, sem problemas. Só que sabe como é menino! Quando estávamos com a barriga cheia e não tínhamos mais o que fazer, ficávamos fazendo 
janelinhas nas outras melancias, só para ver se estavam maduras, já pensou? Coisa de menino "malino".

Seu Antônio Romano, vendo aquilo, no dia seguinte, não gostou, é claro! Ele foi à fazenda contar o que houve para papai e pedir que nos aconselhasse a não fazer mais aquilo.

Papai nos chamou e, na frente dele, nos deu um carão e disse que se acontecesse novamente íamos apanhar e, ainda, autorizou Seu Antônio Romano fazer o mesmo.

Lembro-me que Seu Antônio Romano disse: "não compadre, só queria mesmo que o Senhor falasse com eles, gosto muito dos bichim”. Papai fez a gente dizer para ele que isso não iria mais acontecer, e assim fizemos e ficamos envergonhados. Outra grande lição!

\section{$3.40 \mathrm{O}$ troco errado}

Tem um fato que nunca esqueci. Quando criança, estudava em Crateús. Ao voltar da escola, passando pela rua do comércio, vi uns pentes coloridos que achei muito legal e diferente. Fiquei com muita vontade de comprar um, mas, naquele momento, não tinha dinheiro. Fiquei com aquela demanda de consumo. Já pensou um pente! Coisa de criança.

Para minha felicidade, quando cheguei a minha casa, papai tinha chegado da Lagoa das Pedras. Contei para ele do meu desejo e, na mesma hora, ele me deu o dinheiro para eu ir comprar. Fui todo satisfeito, cheguei, escolhi um pente e paguei o dono do comércio. No momento que estava lá, o vendedor estava atendendo outros fregueses. Quando me deu o troco, percebi que era bem mais do que eu teria que ter recebido. Lembro que falei com o senhor, dizendo que o troco estava errado, mas ele retrucou, de forma meio grosseira, dizendo que eu tinha que ter falado na hora que recebi. 
Fui embora, confesso que não estava confortável. Chegando a casa, disse ao papai o que tinha acontecido, ele, imediatamente, disse que eu fosse devolver, pois aquele dinheiro não era meu. E, assim, fiz, fui devolver o dinheiro, aí, o homem estava só e teve tempo de me ouvir. Ficou muito grato e mandou que eu escolhesse outro pente, como forma de recompensa. Neste episódio, duas coisas muito importantes: aprendi sobre o que era ser honesto e grato. 


\section{Exnane Fosé Oaxres Sfima}

Sobrinho, empresário, casado com Edna, tem três filhos.

\subsection{O campeão largado na cancela}

Minha primeira ida à Lagoa foi com a permissão da minha mãe, em minhas férias de final de ano, na responsabilidade de minha avó, Mãe Zezé. Peguei um ônibus em Fortaleza e desci no Monteiro. Ao descer do ônibus, lá estava um morador da Fazenda a minha espera, um menino da minha idade, era o Edmilson.

Nesse período, João de Deus tinha um cavalo muito arisco e corredor. Numa bela tarde, João me colocou no dito cavalo e Edmilson no cavalo do tio Manoelzinho, de nome "Retrato". Subimos nos cavalos para fazer uma corrida, decidimos que o trajeto seria da casa do Virgílio até a frente da casa da fazenda.

Edmilson mais acostumado a montar cavalos, pois morava na fazenda, e eu com a cara e a coragem.

Peguei o cavalo mais forte a mando do João e, nessa párea, consegui vencer a disputa. Só teve um pequeno detalhe: não consegui frear o cavalo. Não tinha força. Como a porteira estava fechada, o cavalo, ao chegar, travou as patas no chão e me jogou de costas nela. Correram todos preocupados ao meu encontro, pois a pancada tinha sido grande. Mesmo com dor, finalmente consegui me levantar. Minhas costas estavam todas arranhadas e sangrando.

Fui proibido de falar o acontecido para Mãe Zezé e tia Estrelinha. Passei três meses sem tirar a camisa, mesmo com o tempo estando quente. Um dia, na hora do almoço, Mãe Zezé me fez tirar a camisa, alegando que estava muito quente. 
Ao tirar a camisa, ela viu minhas costas arranhadas! Ai, menino, a briga foi grande, principalmente com o João de Deus, dizendo desse jeito: “João, tu vai matar meu neto!" Todos rindo. Foram muitas as aventuras na Fazenda Lagoa das Pedras. Essa eu não esqueço, muito boa, porém muito perigosa. Graças a Deus que tudo terminou bem e ninguém ficou de castigo, pois o pior já tinha passado. A estratégia parece que deu certo. 


\section{Foãa de ODeus de Baveralha Oreira}

Filho, agropecuarista, casado com Ângela Carvalho Machado, tem três filhas: Maria Estrela, Marília e Mirla, e três netos: Nailton Filho, Lia e Marina.

\subsection{Só um fiozinho desligado}

Sou o filho que mais convivi com meus pais, pois terminei o curso técnico de contabilidade em Crateús, porém, meu sonho mesmo sempre era ser fazendeiro, criar gado, e foi o que fiz com o apoio de meu pai, pois o que ele queria mesmo era nos ver felizes.

Bem cedo, com meus vinte e poucos anos, já morava na fazenda com eles. Para mim, foi um grande aprendizado. Mesmo depois de casado, passava a semana na fazenda. Na realidade, eu era a companhia certa deles, pois os outros irmãos moravam fora.

Papai nunca se interessou por dirigir. Tinha motorista, o que passou mais tempo trabalhando para ele foi o Sebastião Marques. Lembro-me que Sebastião chegava bem cedinho, mas acabava saindo lá para às 10h; ele tinha uma característica de dar "massada", nunca saía na hora combinada. Por várias vezes, vi Sebastião tirando uma "sonequinha" debaixo do carro.

Até que cresci, virei homem e passei a fazer as viagens com ele. Ele tinha um grande apego por sua picape verde-escura, chegou mesmo até mandar reformá-la toda, cobrir os bancos, tudo isso, para não trocá-la.

Mesmo reformada, a picape, já velha, vivia nos deixando no prego, nada muito sério, mas era muito chato. Eu sempre sugeria que ele trocasse, mas ele me dizia: "meu filho, o carro é bom!"

Nas nossas viagens, a maioria delas era para Piauí e Crateús, eram raras as vezes que não precisávamos dar uma paradinha por algum probleminha.

Ele sem entender nada de carro, sempre que ficávamos no "prego", naquele sol "rachante" do Piauí, ele procurava logo uma sombrinha nas árvores e ficava 
fumando seu cigarrinho na maior tranquilidade e me dizia: "Calma, meu filho, isso é só um fiozinho desligado". Mesmo eu sabendo que não era nada de fiozinho desligado, aquela calma dele me acalmava. São muitas as histórias que vivenciamos juntos.

\subsection{Os cuidados de minha mãe}

Quando ia para as festas, voltava já no dia amanhecendo. Ao chegar cedinho, lá estava ela a minha espera, assistindo à missa do Padre Zezinho e me dizia: "Isso são horas? Seu cabrito!"

Esquentava um caldinho para mim e dizia que fosse me deitar, pois devia estar cansado. Já quase dormindo, percebia que ela se aproximava devagarinho para conferir se havia dois lençóis na minha rede, pois sabia que só dormia com dois lençóis.

\subsection{Jogo de baralho}

Eu, Toinho e Helder jogávamos baralho até tarde, à luz de lamparina, depois de algumas advertências de mamãe: "vão dormir que já é tarde, íamos dormir".

Tínhamos uma aposta que era o seguinte: quem ganhasse a partida, tomava coalhada, quem perdia, ficava com o soro. Quando Toinho perdia, ficava aborrecido, e a gente ainda para fazer encher o saco, ficava passando por debaixo da rede dele, era de lascar! Ele se levantava zangado e a gente ficava se torcendo de rir. Tempos bons!

\subsection{O "cabra" que desafiou um desembargador}

Essa história era uma das que meu pai mais gostava de contar. Dr. Lúcio, dono do Cartório de Tauá-CE, era aquele tipo de homem rústico, verdadeiro, destemido, que não levava desaforo para casa, como diz o sertanejo: "mais bruto do que canto de cerca".

Na época, houve umas mudanças no Poder Judiciário e alguns serviços dos cartórios passaram a ser gratuitos, entretanto, Senhor Lúcio continuava a cobrar por 
aqueles serviços. O Juiz foi informado sobre o que estava acontecendo e mandou notificá-lo para falar a respeito do que estava acontecendo.

A conversa entre ele e o Juiz de Direito ficou acirrada, quando o Juiz o comunicou que estava agindo errado ao cobrar as taxas que seriam gratuitas para a população. O homem, que nunca tinha sido chamado a atenção, se zangou, chegando às vias de fato, chegando a dar um soco no Juiz, ficando imediatamente preso, é claro! Por abuso de autoridade.

Ao ir se defender no Tribunal de Justiça do Estado do Ceará, o desembargador, quando o viu na sala de espera, foi na besteira de dizer: “Ah! Esse aí é o "cabra" que bate em Juiz de Direito"; ele respondeu: "Sim, e em desembargador também, mas só se for preciso!" Ele adorava essa história!

Poesias sobre a cidade de Castelo-PI que papai gostava de recitar (Quintino Cunha) Pensão Castelo - Quintino Cunha (rábula e poeta), defendendo uma causa na cidade de Castelo-PI, hospedou-se numa pensão que além de não ter o "toalete" limpo, ainda tinha uma culinária muito ruim. Ao sair, deixou escrito na parede do banheiro da pensão: "Castelo, velho Castelo, nunca mais me hospedo em tu, criei ferrugem nos dente e casa de arreia no cu." Parágrafo deslocado.

\subsection{6 $\mathrm{O}$ açougue da cidade de Castelo-PI}

Em Teresina, mata-se trinta e seis bois, em Oeiras, dezesseis, Picos mata oito e Florença mata três, Castelo mata uma porca, e não são todos os meses, quando a feira é muito boa, vende um quarto e salga três.

\subsection{7 $\mathrm{O}$ padre e a onça}

Quando Quintino Cunha, já saindo da cidade de Castelo, passou em frente à Igreja e viu que o patamar estava tomado de matos por todos os lados, falou: “Castelo, velho Castelo, terra que troveja e relampeja, tenho medo que a onça coma o padre na porta da Igreja." 


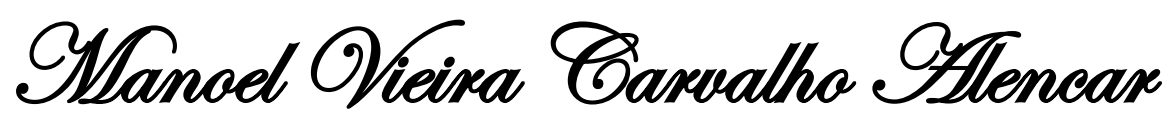

Neto, psicólogo, casado com Nara, tem dois filhos: Isaac e Beatriz.

\subsection{Fazenda Lagoa das Pedras}

Todo adulto tem uma lembrança de um lugar essencial que passava suas férias escolares da infância. Para alguns, é a casa dos avós, outros, a casa de praia da família. Para mim, meus irmãos e primos, era a fazenda da família de minha mãe. A Fazenda Lagoa das Pedras, a fazenda dos meus saudosos avós, Manoel Carvalho (Manoelzinho), do qual tive a honra de herdar o nome, e da grande mulher, minha avó Estrelinha.

Um lugar mágico! Que para mim e meus irmãos, não era apenas um lugar que passávamos as férias, longe de toda a rotina de uma cidade grande. Repleto de animais típicos de uma fazenda, cavalos, bois, cabras, etc. Mas também da natureza característica e marcante da região dos sertões cearenses (Inhamuns). Porém, para nós, era também um lugar grande de confraternização e de proximidade com os nossos avós, tios e primos que moravam tão distantes, pois uma grande distância nos separa ainda hoje desta região que é o berço da nossa família, são mais de $1.500 \mathrm{Km}$ da cidade onde moro, Maceió-AL para o local da Fazenda Lagoa das Pedras, município de Quiterianópolis-CE.

Mesmo com tamanha distância e o cansaço da viagem, normalmente, dois dias de carro, nós aguardávamos ansiosos pelas férias do inverno no mês de julho e as de fim de ano, em dezembro.

Éramos crianças da cidade, mas, ao chegarmos na fazenda, nos tornávamos "matutos" do sertão, apaixonados por todas as pequenas coisas que faziam parte da rotina de uma fazenda. E, cabe lembrar que até próximo a minha adolescência, não havia energia na fazenda. Então, televisão não era uma opção de lazer para nós. Mas quem lembrava dela? Todos os dias competíamos entre nós, irmãos e primos, para ver 
quem acordava mais cedo, geralmente, às 5 horas da manhã, para ver a ordenha das vacas e tomar um leitinho fresco, quentinho, no copo, no curral.

Passávamos o dia entre os currais dos cavalos, dos bois e vacas, das cabras e dos bodes, entre as diversas atividades que nossos avós e tios, sempre muitos atenciosos e com muito amor, desenvolviam para nós. Imagine um menino da cidade, com seus oito a nove anos, passar uma manhã inteira pastorando gado em cima de um cavalo? E que tal, ainda nesta idade, viajar horas e horas a cavalo, com seus irmãos e primos da mesma idade, e os vaqueiros da fazenda, levando mais de 50 cabeças de gados de uma fazenda para a outra. Só quem viveu essas aventuras no sertão sabe da emoção e do quanto tudo isso marca para sempre a imaginação e as lembranças de uma criança.

Lembro-me das várias noites que, cercado pelos tios e pelas tias, fazíamos fogueira em frente à casa da fazenda para contar "estórias" e contos, sob um céu estrelado que um morador da cidade não tem ideia que existe.

Hoje, sou pai de um casal, Isaac, com 19 anos e Beatriz, com 14 anos. Mas, quando eles ainda eram pequenos, sempre procurei levá-los para passar as férias na fazenda, bem verdade que não foram tantas férias como eu gostaria de ter levado. Mas, até hoje, meus filhos guardam um grande carinho e uma enorme vontade de passarem suas férias na fazenda.

E o que dizer de mim? Sempre que volto à Lagoa das Pedras, para mim, é como uma peregrinação espiritual. Não há lugar que me sinta mais conectado com o que há de mais sagrado nesse mundo. Sentir o cheiro do mato, dos animais.

Ter momento com os membros da Família Carvalho que carrego no nome e no sangue. É algo indescritível. Hoje, tenho plena convicção de que o homem que sou se deve muito aos momentos que passei na fazenda de meus avós, pois, a semente de amor que eles plantaram até hoje brota.

O amor pela fazenda, pelos mistérios, pelos encantamentos do sertão cearense e, principalmente, pela convivência e união da família continua vivo e aceso em seus filhos, netos e bisnetos.

Quero agradecer a minha mãe Danúbia, aos meus tios Carvalho, João de Deus, Antônio Luiz e tio Antonino; minhas tias Lucimar, Dalva, tia Ana e tia Lela, que 
não mediram esforços para manter viva a união da família e as tão sonhadas férias na Fazenda Lagoa das Pedras.

\subsection{Um dia de cães!}

Todos nós, membros da Família Carvalho, temos muitas belas histórias para contar sobre momentos que passamos na fazenda.

Uma das lembranças que tenho das minhas férias na fazenda, na época desse ocorrido, acredito que devia ter cinco ou seis anos de idade, foi um dia que, vou chamar aqui de "um dia de cães".

Como de costume, eu e meus irmãos mais velhos, Alencar e Ossianúbia, passeávamos pelos currais da fazenda. Nessa época, tínhamos escutado histórias de que cães selvagens e raivosos andavam pela redondeza, porém, essas histórias impediram que nós, crianças nessa faixa de idade, explorássemos as áreas externas da fazenda.

Uma certa manhã, voltamos do banho no rio que passava por trás da casa. Resolvemos vir pela parte alta do rio, caminho entre a casa de Seu Virgílio e o curral, onde se ordenavam as vacas. Uns 100 ou talvez 200 metros para chegarmos ao curral, escutamos barulhos e latidos de cães. Para nosso desespero, não eram os cães da fazenda, mas os temidos cachorros selvagens.

Meu irmão mais velho, Alencar, gritou para corrermos. Corremos gritando desesperadamente. Nesta hora, nossos tios, Carvalho e João, apareceram na sacada da casa. Ouvíamos um assobio e o grito de ordem: “Bolinha, Jagunço! Vão”, os dois cachorros da fazenda.

Nessa hora, os nossos cachorros correram em direção às três crianças que fugiam loucamente dos cães selvagens. Passaram direto por nós, atacando os cachorros que nos perseguiam, Jagunço e Bolinha lutavam contra aqueles cachorros que, mesmo em menor número, fugiram com medo deles.

Este foi um dia que até hoje lembro com carinho desses dois queridos e saudosos cachorros, e assim guardo na minha lembrança "Um dia de cães na Fazenda Lagoa das Pedras".

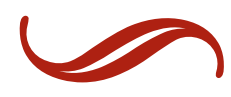




\section{Bándida Mayaxa Orodrigues Baxvalho}

Neta, médica, filha de Ana Isabel, casada com Rodrigo Dantas.

\subsection{A árdua disputa pelo Pampinha}

A Lagoa das Pedras é um lugar recheado de histórias; lembro-me que quando criança, ao dormir, minha mãe já me contava inúmeras histórias de lá. Um local de muita fantasia, histórias de vivência mesmo.

Férias na casa dos avós, ainda mais uma fazenda, meu filho, era bom demais, era nossa própria Disney! Sempre fui apaixonada por cavalos e o que mais gostava de fazer lá era andar a cavalo.

Numa dessas férias, tinha de onze para doze anos, aconteceu um fato muito curioso e até cômico. Havia um cavalinho do tio Antônio Luiz de nome Pampinha que era muito especial; adorava andar nele, havia uma ótima sintonia entre nós, até parece que ele me reconhecia. Na época, quem cuidava com a oportunidade de desfrutar do cavalo era o Senhor Branco, morador da Carnaúba, bairro da fazenda.

Sempre que chegava de férias, era um transtorno para Seu Branco, coitado! Tipo: “Ah, meu Deus, lá se vem a menina querendo o cavalo". Era uma luta a ferro e fogo pelo cavalo, pois eu sempre estava querendo o cavalo e ele precisando dele para a labuta. Quando eu chegava à fazenda, dava logo um jeito de mandar avisar que havia chegado e que queria que ele levasse o cavalo para a casa sede.

Houve uma vez que cheguei, pedi que o avisassem que tinha chegado, mas nada de ele trazer o animal. Sempre que ia pela Lagoa, me prometia que no dia seguinte traria e, assim, já haviam se passado uns três dias e nada. Meus tios sempre dizendo que ele iria trazer, mas nada de cavalo.

A Carnaúba fica uns dois quilômetros da casa da fazenda, para ir a pé era longe. Já estava ansiosíssima, pois era minha diversão. Não tive dúvida, sempre fui muito decidida sobre o que queria. 
Eram 2 horas da tarde, o sol estava rachando, para não ir só, chamei o Lorim, colaborador da fazenda que se disponibilizou a ir naquela hora comigo, isso, é claro, sem ninguém saber! E lá fomos nós. O sol era tão quente que a gente via como se estivesse subindo uma fumaça transparente.

Como eu já estava muito desconfiada que Seu Branco estava me enrolando, fiz questão de chegar de surpresa. E foi uma surpresa mesmo, pois ao chegar, o quintal (terreiro atrás da casa), peguei Seu Branco de cócoras fazendo o número dois. O coitado saiu correndo com as calças na mão e dizendo: “Oh! Menina danada! Saia daqui!" Eu também estava bastante constrangida, mas rindo muito e Lourim me dizendo para eu não rir e disse a ele o seguinte: "que só ia embora dali com o Pampinha". Foi o único jeito que encontrei para ter o Pampinha para mim naqueles dias. Dias inesquecíveis e que não voltarão jamais!

\subsection{Montaria com meus primos}

Uma das nossas maiores diversões era mesmo montar a cavalo, eu e Victor adoramos até hoje. Quando dava certo para ir com a turma dos primos, era diversão garantida. A gente já tinha os cavalos preferidos. Eu andava no Pampinha; o Victor, no Grã-fino; e a Marília, no Guarani, do pai dela.

Estavam também lá a tia Dalva com as meninas, Marianna e Julianna. Também queriam ir. Daí foram buscar na roça uma burra mansa do tio Antonino, para Marianna e Julianna montarem. Depois de quase uma hora para os rapazes arrearem os animais, finalmente partimos mais uma vez para Carnaúba, rota escolhida por ser uma estrada bastante plana.

Ao sairmos, combinamos uma brincadeira que era o seguinte: sempre que passássemos por uma moita, falaríamos uma frase. Uns de nós falaríamos: “Vida de vaqueiro?" E os outros responderiam: “Vida de vaqueiro!" Bem coisa de criança.

Numa dessas vidas de vaqueiro, a burra que estava com Marianna e Julianna se assustou com os nossos gritos e se espantou, disparando com elas e derrubando-as debaixo de uma moita. Foi uma Vida de vaqueiro plena! Sabe como é criança! Foi uma risadaria sem fim! Deu uma crise de riso no Victor e na Marília que 
eles não paravam de rir. Eu, a mais humanitária, brigando com eles, preocupada e com medo de ter acontecido algo mais grave.

Graças a Deus só alguns arranhões, que é claro que éramos proibidos de falar do acontecido ao chegar a casa. Tia Dalva nunca ficou sabendo desse pequeno acidente com as meninas. Não tenho dúvida de que as crianças são, permanentemente, protegidas pelos seus anjos da guarda. Amém!

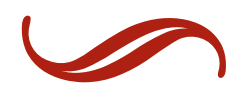




\section{Mista Gareatho de MSachado}

Neta, nutricionista, filha de João de Deus, solteira.

\subsection{São muitos os meus contos!}

Não tenho um só relato em especial, mas vários! Gozei de uma infância cheia de aventuras e muito feliz na minha amada Lagoa das Pedras, como carinhosamente chamamos; tive a felicidade de poder conviver com meus avós e primos.

Foram muitas as travessuras e brincadeiras na lagoa: banho de rio e açude, só pela manhã! Vovó dizia que à tarde fazia mal. Quando chovia, íamos brincar na lama, ao lado da casa da fazenda; andávamos a cavalo, colocávamos o gado no curral; passeávamos na casa do tio Virgílio e da Raimundo do Seu Branco; fazíamos comidinha embaixo do pé de umbu; brincávamos nas pedras das lajens; no inverno, pulávamos das oiticicas no Rio Poti, para sermos carregados pela correnteza.

E as cajás que desciam no rio? Hum! Comia tanto que ficava com a língua amarela. Contávamos as estrelas nas noites escuras, apenas à luz de lamparina, quando ainda não havia energia, ouvindo o barulho do cata-vento e das algarobas; brincávamos de pegar vagalume (inseto luminoso), de adivinhação na calçada, de roda no terreiro, de trinta e um na mancha, de cabra-cega, de se balançar nas redes que, aqui e acolá, caía uma e a vovó acabava com a brincadeira, dizendo que já estava na hora de dormir; obedecíamos cegamente! Entre muitas outras tantas maravilhas...

Lembranças que nem o tempo conseguiu apagar! Gratidão aos meus avós paternos, pela família linda que nos deu e por esse lugar encantador que se chama Lagoa das Pedras dos Carvalhos.

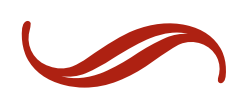




\section{Maria de Tratima Monte Barealho}

Nora, odontóloga, casada com Antonino, tem um filho e as netas.

\subsection{Minhas primeiras impressões}

Meu primeiro passeio na Lagoa das Pedras, ainda não era casada com Antonino, mas já havia me apresentado aos seus pais como sua noiva. Para não vir só com Antonino, pois naquela época não era comum os namorados viajarem sozinhos, convidei uma amiga minha de nome Aparecida.

Saímos cedinho de Natal-RN e resolvemos pernoitar em Tauá-CE, pois não queríamos chegar à noite. Saímos pela manhã para a fazenda, chegamos para o almoço. Dona Estrelinha, muito hospitaleira, já nos aguardava com um almoço todo especial. Sua maior preocupação era nos acomodar para ficarmos mais confortáveis o possível, já nos mostrando as dormidas, ou seja, onde cada um iria dormir. Seu Manoelzinho também muito educado e gentil com todos que por lá passavam; ele fazia questão de nos apresentar como doutora Fátima e Aparecida, sempre demonstrando o prazer de nos receber na fazenda. A tarde passou rapidinho. Depois de um belo almoço com mesa farta, acompanhado de um bom papo, Dona Estrelinha nos convidou para dormir um soninho na sala chamada "varanda", sala de visitas, onde ficavam todos, homens e mulheres, como se fosse um alpendre.

Enquanto descansávamos, já a escutava dando as coordenadas para o jantar. Ela tinha várias auxiliares; algumas moças moravam com ela, outras eram voluntárias, moradoras da fazenda que ela sempre agradava. Dona Estrelinha era muito social e conversadeira, sempre de olho no trabalho das mulheres na cozinha.

E a noite do sertão chegou, uma noite escura e estrelada, coisa que a gente não consegue ver na cidade. Admirável! No jantar, já ficamos sabendo que depois íamos para a calçada apreciar a noite, já era hábito.

Na época, havia um motorzinho movido à gasolina que Seu Manoelzinho ganhou do seu genro Ossian, esposo de Danúbia. Iluminava todo o eixo central da 
casa, mas como a casa é muito grande, era necessária a luz das lamparinas para clarear os quartos. Foi uma noite muito agradável.

Sentamos na calçada e depois de boas "estórias" de Seu Manoelzinho, fomos nos acomodar. Dona Estrelinha nos levou ao quarto que era das filhas e fez questão de frisar que aquele quarto era apenas das mulheres. Redes e lençóis cheirosos. Foi uma noite muito agradável!

No dia seguinte, nos deparamos com a mesa farta, cheia das delícias do sertão: pão de milho, tapioca, cuscuz, queijo, leite, café cheiroso, um bolinho de milho que gostei muito, chamado "jumento". Nunca entendi o porquê daquele nome! Porém, não fazia a menor diferença, pois era uma delícia!

A casa era movimentadíssima, não dava para decorar o nome de todos que tinham uma função, os quais eram tratados como sendo da família. Dona Estrelinha nos sugeriu um banho no rio, pois ainda era inverno e os poços estavam cheios. Fomos, eu e Aparecida, acompanhadas pela Dona Francisca, uma das moradoras mais antigas, já beirando os 60 anos, era quase como uma dama de companhia. Ela era uma graça!

Dizia ela que moça bonita é igual à mercadoria boa, não ficava empancada na prateleira, querendo nos dizer que nós não ficaríamos. Ríamos tanto, era muito divertido. E foram assim, nesse ritmo, aqueles três dias que passamos lá. A rotina da fazenda já era a própria programação.

Um casal muito amigo e amoroso com a família e todos aqueles que com eles conviviam; era como uma grande família. Aquela energia boa, um lugar de paz e harmonia. Enfim, um passeio muito agradável que a gente volta para casa com saudades do lugar e das pessoas. Minhas primeiras impressões não podiam ter sido melhores e, com o tempo, tudo aquilo se confirmou. Até hoje, é muito bom estar na fazenda.

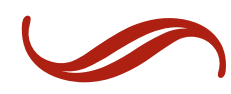




\section{Qhainda Mravia Gaveralho MSourãa}

Filha, bióloga, casada com Francisco Mourão, tem três filhos: Ana Raquel, Christiane e Mourão Filho, e três netas: Júlia, Clara e Mariana.

\subsection{Férias em minha casa Lagoa das Pedras}

Às 14 horas saímos de Crateús no misto (tipo de transporte, uma mistura de caminhão e ônibus) do Senhor João Lima, carregado de gêneros alimentícios e passageiros. Chegávamos às 17 horas no Jatobá do Seu Bentinho (comerciante), onde uma comitiva da fazenda nos esperava. Era aquela festa! Só Deus sabe. Fazíamos a caminhada do Jatobá para a Lagoa das Pedras, regada por muita conversa e novidades. Expectativa? As maiores. O Rio Poti se encontrava com um fio d'água cristalino e bem frio, uma delícia. Meu Deus! Como era bom!

A casa despontava, outra turma a nos esperar, mamãe gritava: alvíssaras! Minha filha chegou. A cara dela! Lelé (Nazaré, uma Senhora doente mental que morava na fazenda) era a mais zoadenta. Lelé, tão pura e inocente, não sabia como expressar sua felicidade, batia palmas de alegria e me falava com seu linguajar peculiar, tentando dizer alguma coisa: “Lubá" (eu), “leso” (tentando dizer que tinha leite), “Bizim” (Manoelzim), “Tela” (Estrela), todos aqueles gestos tentavam mostrar o quanto estava feliz com minha chegada.

Papai viajava muito para o Piauí, mas quando estava na Lagoa das Pedras, infalivelmente, iria ao nosso encontro, seja no Jatobá ou até mesmo em Crateús, se viéssemos de Fortaleza.

Quando fiz minha primeira viagem sozinha para a fazenda, tinha entre 15 e 16 anos, o ônibus passava no Monteiro às 15 horas. Mamãe me aguardava ansiosamente. Mamãe tinha guardado para mim uma cerveja no fundo do pote de água fria, para ficar bem geladinha, vejam só! Ela costumava dizer que a cervejinha “além de ser uma delícia, era digestiva e estomacal." Era moderna para aquela época! 
O desconforto da viagem, a expectativa da viagem, a vibração da chegada, o calor de rachar, tudo me deixou enfadada e, depois daquela cervejinha, saí da mesa direto para a cama e tive uma noite de sono reconfortante, acordando no dia seguinte refeita e cheia de alegria para viver aqueles dias com meus pais, minha família. Dias que não esquecerei jamais!

\subsection{Voto secreto}

Ainda nos dias de hoje temos o voto de "cabresto", vocês imaginem há 50 anos atrás! Naquela época, havia os coronéis que eram homens muito respeitados, donos de terra, gado, ou seja, homens que tinham o poder da riqueza e que tinham grande influência política, tanto para eleger o gestor municipal quanto para a eleição de deputado estadual.

O Coronel Feitosa era o grande influenciador político, "cabo eleitoral" da cidade de Tauá.

As pessoas contavam que seus moradores e influenciáveis iam à fazenda dele no município de Tauá só entregar o título para que ele mesmo votasse por eles. Já pensou?

Um de seus moradores, ao vir pegar o título eleitoral, depois das eleições, perguntou: "Deu certo, Coroné?" Ele respondeu que sim, deu certo. O senhor, dono do título, humildemente perguntou por simples curiosidade: “Coroné, só pra saber mesmo, eu votei em quem?” Ele respondeu: “Ora, ora cabra, você não sabe que o voto é secreto!"

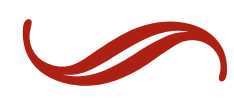




\section{Maretia MSachado Garvalho}

Neta, fonoaudióloga, filha de João de Deus, casada com Wagner, tem duas filhas.

\subsection{Minha doce e inesquecível infância na casa da Vovó Estrelinha e do Vovô Manoelzinho}

Quando se fala em Lagoa das Pedras, muitas coisas vêm a minha mente. A primeira delas são os "sabores da infância”, provenientes dos doces e quitutes da vovó Estrelinha: doce de leite, galinha caipira, rosquinhas, coalhada com rapadura, cuscuz com leite, bolo de milho, tapioca, no inverno; milho verde assado e cozido, canjica, pamonha, melancia, jerimum; fora as frutas de época: manga, ata, banana, caju, cajá e tantas mais.

Lagoa das Pedras me lembra os meses que eu e minha mãe passávamos lá, para que a vovó fosse para suas consultas em Fortaleza. E as campanhas políticas do tio Antônio Luiz? Eram uma grande animação, todos íamos para Quiterianópolis e eu ficava chorando para ir também. Tia Mazé dizia: "pode chorar que não morre não e ainda fortalece os pulmões". Mas, logo em seguida, me consolava com suas moedinhas e histórias da sua neta Sacha, que eu adorava.

A casa da vovó também me traz saudosas recordações das férias, brincadeiras e principalmente o convívio com os primos e coleguinhas da fazenda que foram grandes companheiros de inúmeras brincadeiras, simples, mas muito boas e que hoje não parecem existir mais.

Foram muitas aventuras cotidianas que não esqueço, pois o dia na fazenda já era a própria diversão: andar a cavalo o tempo todo e, ao chegar, aquele carão do pai por termos cansado os cavalos, já sabíamos! Passear nas casas da Nem, na Mucunã, tia Raimunda na Carnaúba, mexer o doce de leite da vovó, pois depois de feito, estávamos autorizados a comer o pregado da panela ainda quente, dar comida às galinhas, procurar ovos de capote, acordar bem cedinho para tomar leite mugido, 
assistir matança de porco, andar nas vazantes cheias e voltar toda suja de lama, tomar banho de rio e açude, fazer "açudinho" na chuva, correr, apenas correr, levar carreira de vaca brava, ouvir o barulho da chuva e o cheiro de mato molhado, brincar de "esconde esconde" na mata, fazer piquenique no pé de umbu, encolher-se todinha com medo de trovão, caçar vagalumes e prender numa caixa de fósforo. À noite, ouvir "estórias" engraçadas do pai e dos tios, ir à bodega de Seu Francimar comprar balas e anotar na conta do pai, comer o leite ninho do Guilherme Matheus, ainda bebê, escondido da tia Lela, é claro! Que só agora vai descobrir! Incentivada pelo Victor! Na maioria das aventuras, já tínhamos certeza de que o carão era certo, mas o custobenefício valia a pena.

Outra coisa que nos deixava muito eufóricos era a chegada dos nossos tios e primos que moravam longe. Aquelas refeições, sempre muito fartas com toda a família junta, sempre conversando e rindo, não esqueço.

Tomar a bênção dos tios e avós e ter a mão e a cabeça acariciadas e beijadas, nossa! Quantas lembranças que ficarão guardadas para sempre! Com muito orgulho e saudade, tentarei passar para a Lia e Marina.

Lembro-me também muito dos carões da vovó porque a gente andava descalça no terreiro e ela ficava tossindo. Ela dizia: "à noite é só o tefo tefo, vão tudo entrar na banha de galinha". "Tefo tefo", ela se referia à tosse, e a tão indesejada banha de galinha, o remédio; e tomava mesmo.

Minha infância foi praticamente na fazenda dos meus avós, lá brinquei de fazendeira, fui dona de casa, brinquei de ser mãe, vaqueira, eram muitas as fantasias. Enfim, fui apenas uma criança feliz!

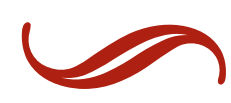




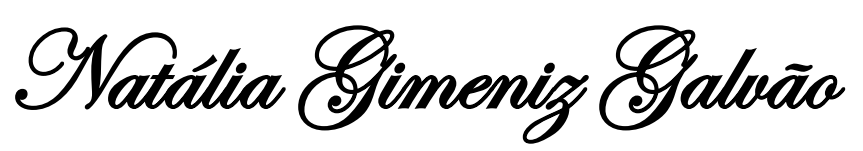

Acadêmica de Medicina, minha convidada especial.

\subsection{Quinze anos do sertão}

Desde que conheço Guilherme, sempre me falou da fazendo dos avós. De tanto ele falar, fui ficando com aquela curiosidade. Até que um dia, deu certo para ir com a tia Aurélia. O carro dela ia lotado de coisas para o rancho, cheio de plantas e outras coisas, só tinha mesmo o lugar de sentar. Mas, uma viagem tranquila.

O sertão, para mim, era uma coisa nova, apesar de meus avós morarem no interior de São Paulo, um local completamente diferente. Lá não há latifúndios, são pequenos sítios de seis, dez hectares, mas bastante produtivos e de clima, na maior parte do ano, frio.

Então, não tinha como não ser bom, pois tudo era diferente e novo. Logo no dia que chegamos, tio Carvalho nos falou que havia um aniversário de quinze anos da filha do Senhor José da Cruz, ex-morador da fazenda e que a gente iria. Porém, comentei com tia Aurélia que não havia levado roupa adequada para um aniversário de quinze anos. Tio Carvalho me falou que não tinha problema, que eu podia ir de short mesmo e ainda me tranquilizou, dizendo que Isabel ia assim. Tudo bem! Achei bem interessante e, até de certa forma, legal esse jeito descomplicado de ir para uma festa de quinze anos.

Nos arrumamos e fomos, bem despojados, nada melhor! Eu, Guilherme, tio Carvalho, tia Silvana, alguns moradores da fazenda e mais alguém que, agora, não recordo.

A festa era na própria casa da aniversariante, do lado de fora da casa (terreiro), todos muito felizes, animados e conversando. Havia umas carnes dependuradas, acho que para assar. O jantar era servido por uma janela, tipo prato executivo. Muito farto e tudo muito sem protocolo, e estava gostoso; carne assada, quem não gosta! 
A única coisa que lembrava uma festa de quinze anos era a mesa decorada com o bolo e balões que normalmente na cidade usa-se em festa de criança, mas estava legal. A aniversariante também estava bem arrumada, de vestido longo e tudo mais. Havia também um cantor, cantando e tocando em um órgão eletrônico. Dava para perceber que a família fez o melhor que pôde.

Sentamos numa calçada bem alta e ficamos olhando o movimento. Aqui e acolá vinha uma pessoa pedir para Gui me apresentar e sempre me dava as boasvindas. A festa deles é um grande encontro da família e amigos para comer, beber e conversar, o que é realmente o sentido de uma festa. Achei tudo muito interessante, principalmente a alegria das pessoas e o prazer de encontrar os conhecidos.

Percebi ali que, na cidade, as festas demandam preocupações desnecessárias, coisas que não vão fazer a menor diferença para o divertimento e a alegria das pessoas. Preocupam-se muito com as etiquetas, aparências e em agradar mais os outros do que a si. Foi um momento inusitado! Pois é, existem muitas formas de nos divertirmos, essa foi uma delas. E foi assim minha primeira noite na Fazenda Lagoa das Pedras. 


\section{Orictox Shanuel ORodrigues Gaxwaltho}

Neto, médico, filho da Ana, a Izabel, médico, solteiro.

\subsection{Aí, nasceu minha paixão por cavalos}

Tenho muitas lembranças de férias inesquecíveis que tive na fazenda de meus avós. São muitas histórias e recordações de uma infância e adolescência cheias de aventuras saudáveis. Fui muito feliz!

Quando se aproximava a época das férias, a ansiedade e vontade de ir já eram grandes. Planejar férias? Que nada, não havia outro destino. Sou um dos netos que mais desfrutou daquele lugar, desfrutei de tudo: ensinamento dos meus avós, carinho dos meus tios, amizade dos moradores, brincadeiras com meus amigos da fazenda, que eram muitos: os filhos do Seu Bomfim, Eudes, Louro, João Paulo, Robertinho; os filhos do Seu Martins: Flaviano, Lerim, Cheiro e muitos outros, inclusive muitos da vizinhança. E, aí, quando chegava à Lagoa das Pedras, era aquele movimento grande de gado, de cavalo, etc.

O que mais gostava era dos cavalos. Ao chegar, já ia direto ao cercado pegar um cavalo que ficaria como meu, ou seja, eu ficava com o cavalo para meu usufruto e, em contrapartida, o cavalo ficava sob meus cuidados, sob minha responsabilidade, ou seja, dava banho, ração, levava para o cercado. Entrava totalmente na rotina dos vaqueiros; como eles falam lá, no manejo. Eu me achava, teoricamente e na prática, sendo dono de um cavalo.

O primeiro cavalo que tive pelo meu comando foi o Xodó, depois o Pampinha, um cavalo do Seu Branco, pois ele era o vaqueiro das ovelhas, por sinal, havia até uma pequena disputa minha e dele pelo cavalo, pois quando chegava, se apossava do Pampinha, e Seu Branco ficava quase a pé, coitado!

Depois de um tempo, subi de nível e já tinha meu cavalo, presente do tio Sandoval, chamado Grã-fino. Todas as tardes ia para Mucunã, à casa de Seu Bomfim, 
hoje o Rancho Mucunã. Também gostava de ir para Carnaúba, à casa de Seu Viana, todos, moradores da fazenda.

Esses lugares são como bairros da Lagoa das Pedras, pois a fazenda é muito grande e meu avó, sabiamente, para facilitar a localização dos animais, colocava nomes nas localidades mais distantes da casa sede, uma boa estratégia, a meu ver. São muitos os lugarejos da fazenda: Carnaúba, Mucunã, Muquém, Lagoa da Madiam Águida, Açude Novo, Açude dos Carvalhos, Canto, Lajes, entre outros.

Quando chegavam as meninas (primas), as tias, os primos, ficava bom demais! Marília e Mayara também adoravam andar a cavalo. Mayara até hoje curte cavalos. Essa nossa paixão por cavalos, não tenho dúvida que nasceu nessa época.

As aventuras eram muitas. Eu, Marília e Mayara montávamos nos cavalos, Julianna num jumento e Mariana numa jumenta amojada, já na época de parir! Aqui e acolá, tínhamos que parar, pois Mariana dizia que o bebê estava mexendo e, aí, ela não continuava de jeito nenhum, enquanto o bebê não parasse de mexer. Era uma comédia!

Outra grande aventura foi a viagem que fiz para o Piauí com os vaqueiros levando 183 cabeças de gado. Foram três dias e meio de viagem. A comitiva era eu, Seu Bomfim, Louro, Haroldinho, este hoje meu compadre, sou padrinho da Aurora. Temos um vínculo muito grande. Outro amigo meu era o Virgilinho; comecei a tomar cachaça com ele. À noite, a gente ia para o Monteiro, localidade vizinha da fazenda, na realidade, o point.

Brincávamos muito na várzea, nos atolando na lama. Já pensou?! Também aprendi a andar de moto lá. Minha primeira viagem de moto, só havia uma semana que eu tinha aprendido a andar. Cheguei à casa da tia Lucinda Marques (vizinha da fazenda) e ela me disse: "soube que agora está nadando de moto! Pois quero que vá me deixar para um almoço no Besouro". Não tive dúvida, pois estava "verminoso" para andar e disse, na hora, que ia. Eu, muito magrinho e ela, alta e gorda, a moto mal encostava o pneu da frente no chão. Até hoje não sei como não aconteceu um grande acidente. Meu Deus!

Tio Antônio Luiz e Padrinho Carvalho, que estavam no almoço do Besouro, quando nos viram, ficaram horrorizados com a coragem da madrinha Lucinda de ir comigo. Também levei aquele carão, pois lá eu ficava na responsabilidade deles. Meus 
tios, todos, eram sempre muito amáveis e cuidadosos comigo. Mamãe ficava tranquila com minha estadia lá.

E são muitas histórias! Aprendi a dirigir na F1000 do tio Augusto. Ele sempre muito disponível e disposto a me ensinar, dizia: "vamos, rapaz, que eu te ensino; você aprende bem ligeirinho, não tem perigo nenhum". E foi assim, sem qualquer protocolo, cheio de emoções. Não esqueço jamais! Pensando bem, as fases mais marcantes da minha vida passei na fazenda dos meus avós.

Quando chegava lá e minhas tias não estavam, eu, uma criança ainda com apenas 10 anos, dormia no mesmo quarto com Mauro e a mãe dele, Dona Fátima. Hoje, ela é minha paciente. Olha só como o mundo dá voltas. Cheguei também a dormir, muitas vezes, na Mucunã, casa da Dona Nem, gente boa, me tratava como um filho.

Outra figura emblemática, hoje quem comanda a casa da fazenda é Marismar, mulher de 70 anos, cheia de energia, amiga de todos nós, sempre dando um jeito para tudo. Gente da melhor qualidade.

Tia Raimunda do Branco, moradora da Carnaúba, onde hoje é a casa do tio João, tinha um pé de seriguela que a gente adorava roubar as frutinhas. Quando ela via que tinha menino tirando seriguela, saía gritando e correndo atrás de nós, era pura adrenalina! Ela sempre me dizia que, quando eu quisesse, era só pedir para ela, pois para mim, ela dava, mas eu queria mesmo era aquela aventura do perigo com meus colegas. Coisa de criança.

Até hoje, a Lagoa das Pedras é um dos locais preferidos e de grandes encontros da Família Carvalho. É sempre muito bom ir para lá.

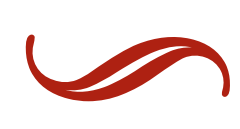




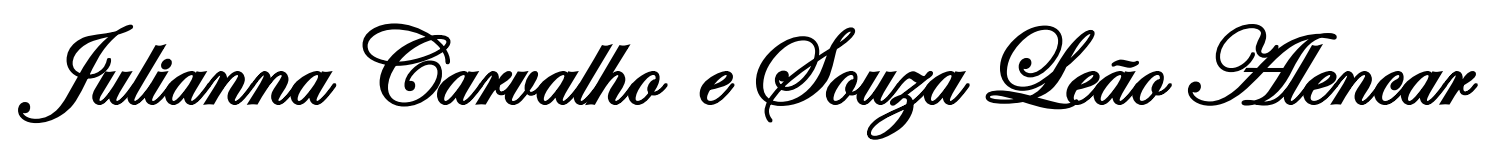

Neta, advogada, filha de Dalva, casada com Heitor Santana, tem um filho.

\subsection{Como não lembrar?!}

Escolher apenas uma história da Lagoa das Pedras é difícil! São lembranças tão vívidas e felizes que sinto agora mesmo o cheiro do mato, o gosto da água de pote e o barulho dos capotes. O pé de umbu era um dos meus lugares preferidos, lá se estendiam as tardes de brincadeiras de casinhas, panelinhas e tudo mais que se possa imaginar. Lembro-me que brincávamos muito com a Dilene, filha da Dona Fátima, moradora da fazenda, sempre muito esperta e resolutiva, principalmente na hora de fazer o fogo para fazermos as comidinhas.

O lema das férias dos primos era "vida de vaqueiro", intitulado por nós e significava que a gente tinha que ter coragem de enfrentar qualquer parada para explorar o ambiente, vulgo "somos raiz". Passávamos o dia andando a cavalo e usufruindo de toda a fazenda, sempre muito bem assessorada pelos meninos, nossos colegas, filhos de moradores de lá, sempre dando as coordenadas.

Quando não tínhamos cavalos suficientes, uns iam de jumento. Foi o caso de Mariana, que arranjou uma jumenta prenha para um dia de aventuras. A ideia não deu muito certo, pois a jumenta disparou na corrida, logo na saída. A crise de riso foi grande!

Minha intenção sempre era de voltar às aulas, a mais lascada possível, pois quanto mais arranhada, mais significava que minhas férias tinham sido divertidas. Papai sempre me dizia que não tinha problema ficar com as manchas de pereba, pois quando eu ficasse adulta, ele mandava tirar tudo a laser, tenho-as até hoje.

Lembro a gente alimentando os cabritos, vendo matar carneiro, boi e as pobrezinhas das galinhas, que eram abatidas torcendo o pescoço. Lembro-me dos dias de chuva com muitos trovões. Mamãe sempre nos dizia que não tivesse medo, pois tinha para-raios. Que nada! 
E como não lembrar do momento de tanger o gado para o curral, do leite quentinho tirado na hora, da parede da varanda com fotos da família, das selas dos cavalos penduradas na sala, dos banhos de açude, das idas e vindas às casas dos moradores. E dos bronzes com Coca-Cola?

Como não lembrar do terreiro, das algarobas, do fogão a lenha, da coalhada, das fogueiras nas noites de lua cheia, do oratório da vovó, dos terços, dos balanços nas redes, das conversas longas logo de manhã?

Como não lembrar do Haroldinho, Zé da Cruz, tio Virgílio, personagens da fazenda que mais pareciam personagens de "estórias" em quadrinhos ou mesmo do Sítio do Pica-pau Amarelo?

Essas lembranças estarão para sempre eternizadas na minha mente e no meu coração! Como não lembrar? 


\section{QDavi Gomes de Gavealho}

Neto, acadêmico de Engenharia Civil, filho de Carvalho e Silvânia, tem uma filha com Lara.

\section{Um relato de Davi}

“Eu fui pra Lagoa das Pedras com meus pais. Gosto de lá porque tem cavalo, cabrito, pavão, jumento, vaca e dois cachorros. Eu também ando de trator com meu papai e vou buscar as vacas no cercado. E, no inverno, tomo banho de rio. Eu adoro esse lugar!"

Fiz esse texto em dezembro de 2011, quando tinha cinco anos, para a produção de um livrinho coletivo da nossa turma de formatura do ABC.

Achei que essas palavras tão inocentes e verdadeiras de apenas uma criança de seis anos, refletem perfeitamente o sentimento de amor que tenho pela Lagoa das Pedras, fazenda que transborda de histórias de meus avós, que apesar de não tê-los conhecido, sinto a forte presença deles naquele lugar. 


\section{QLaxyssa YSaria Oimenes Barwalho}

Neta, advogada, filha de Antônio Luiz, solteira.

\subsection{Enlaçados pelo umbigo e coração}

Desde criança, sempre ouvia meu pai falando que um cordão umbilical foi enterrado perto da porteira da Lagoa das Pedras, para que, assim, meu laço de origem ficasse junto ao solo tão amado por ele. Independente do ritual descrito anteriormente, meus laços e coração já haviam sido amarrados com bons momentos vivenciados nos terreiros da Lagoa.

Nas férias, nos juntávamos e, quando crianças, íamos ao pé de umbu, ficávamos o dia todo brincando de casinha e chegamos até a abrir um "Restaurante dos Carvalhos". O cardápio era sempre o mesmo, macarrão instantâneo com sabor de fumaça, da lenha acesa que trazíamos escondido da Marismar para acender nosso fogão à lenha, feito da junção de tijolos e pedras. Quando era período de chuva, começava a competição de escorregar na lama e tomar banho no rio. Como era bom! Ao chegar à Casa Grande, já sabíamos que o carão era certo, por ter sujado mais uma roupa, o que não nos impedia de fazer tudo de novo.

Já mais crescidos, fomos diminuindo as idas à Lagoa, esses adolescentes rebeldes. Mas, como os laços não se desfazem, percebemos que é lá onde nos alegramos, nos restauramos e nos mantemos família. Com isso vieram nossos encontros tão animados: Semana Santa, São João ou o motivo que tiver para estarmos juntos na terra que nos fez família.

Que a Lagoa das Pedras seja sempre um lugar de bons encontros e certeza de união familiar. E a você, meu pai, agradeço por ter me ensinado a importância de manter uma tradição. Que eu possa, futuramente, retribuir o seu carinho, enterrando o cordão umbilical dos meus filhos no solo forte, fértil e amado da Fazenda Lagoa das Pedras. 


\section{3"Galeria: Animais}

Foto 20 - Curral da Fazenda Lagoa das Pedras

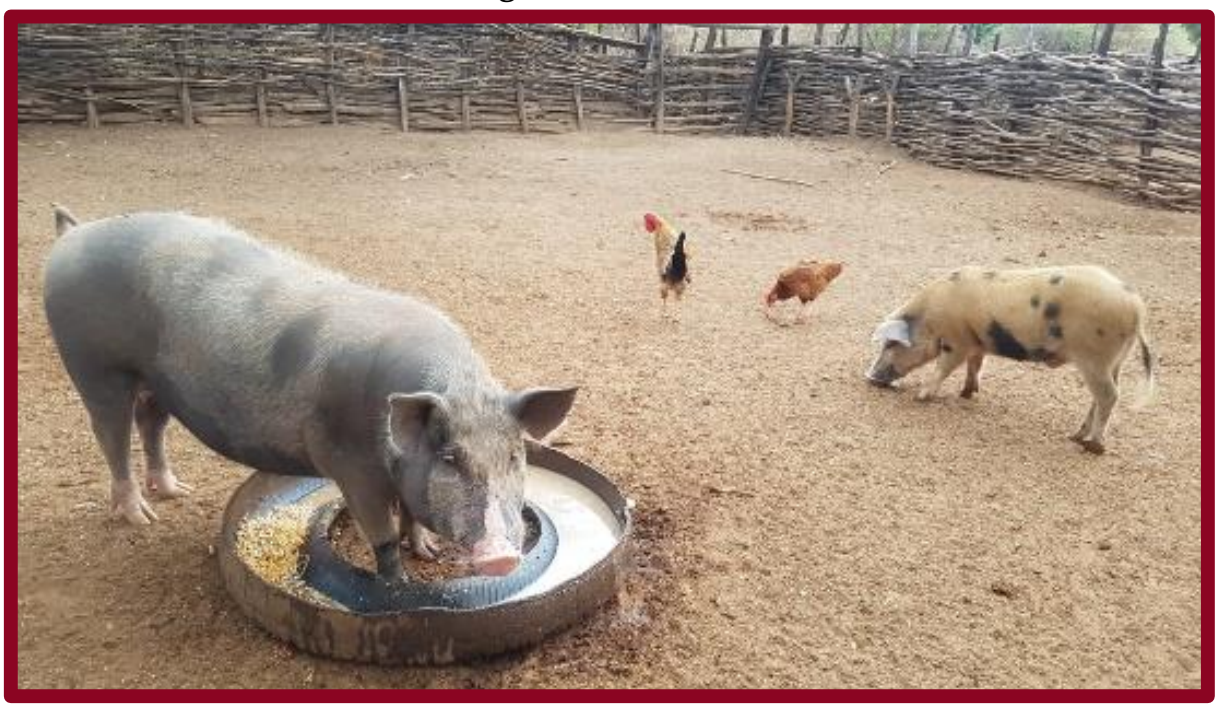

Fonte: Acervo da Família.

Foto 21 - Curral da Fazenda Lagoa das Pedras

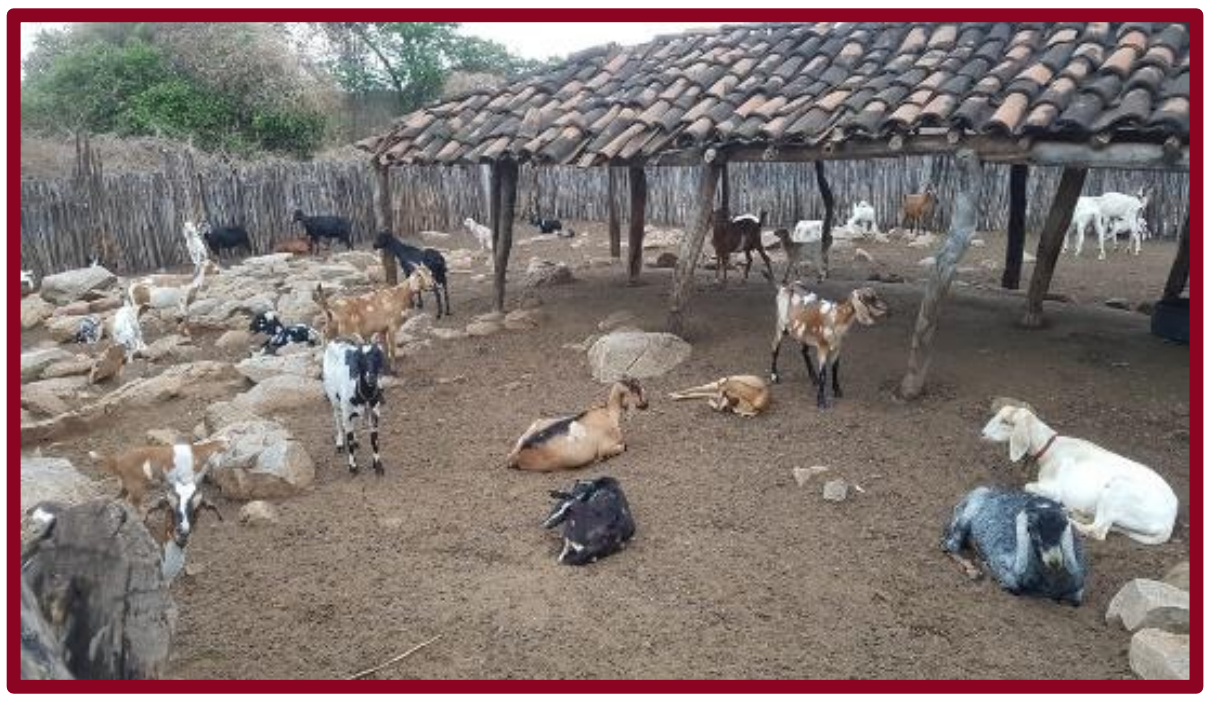

Fonte: Acervo da Família. 


\section{3" Galeria: Animais}

Foto 22 - Curral da Fazenda Lagoa das Pedras

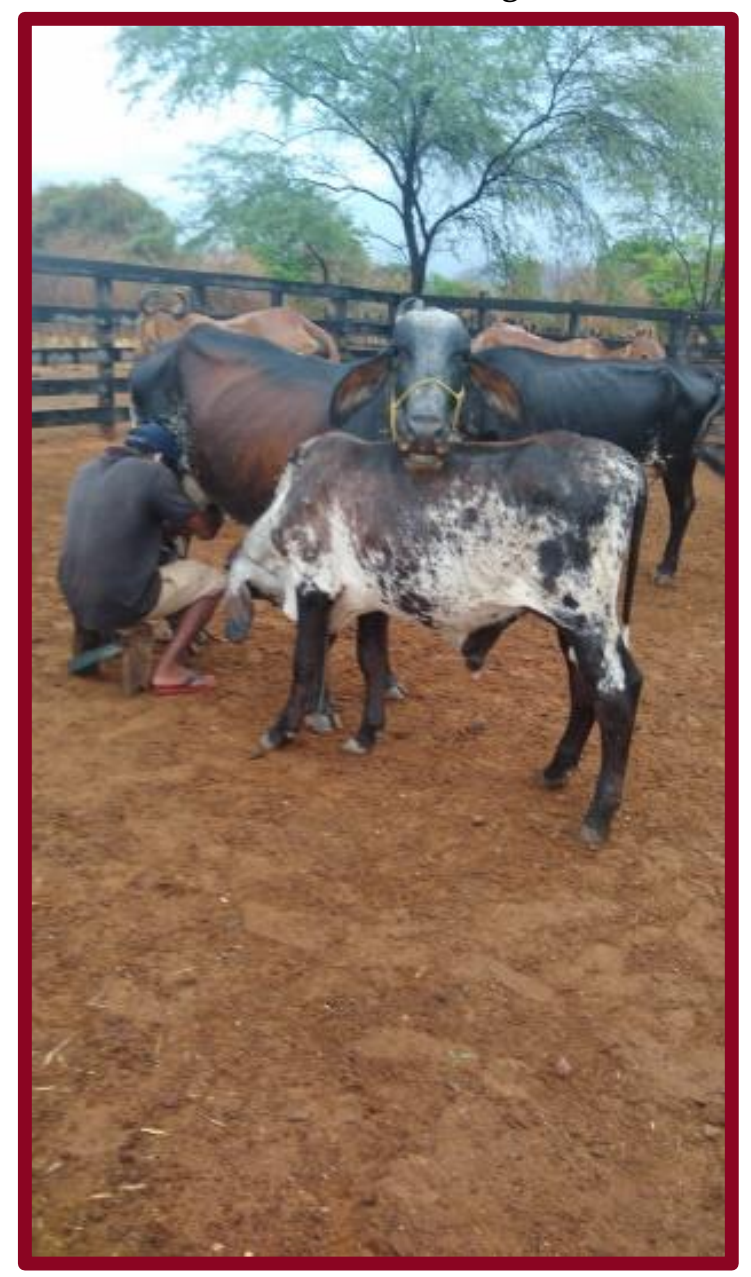

Foto 23 - Curral da Fazenda Lagoa das Pedras

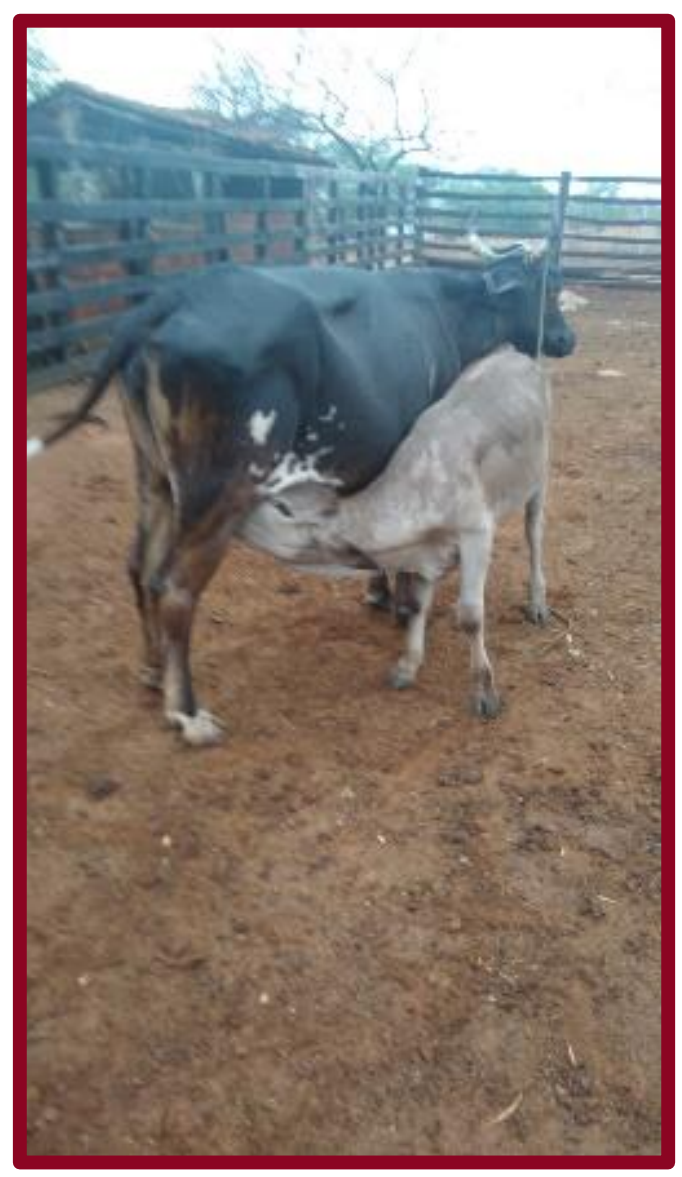

Fonte: Acervo da Família.

Fonte: Acervo da Família. 


\section{3"Galeria: Animais}

Foto 24 - Curral da Fazenda Lagoa das Pedras

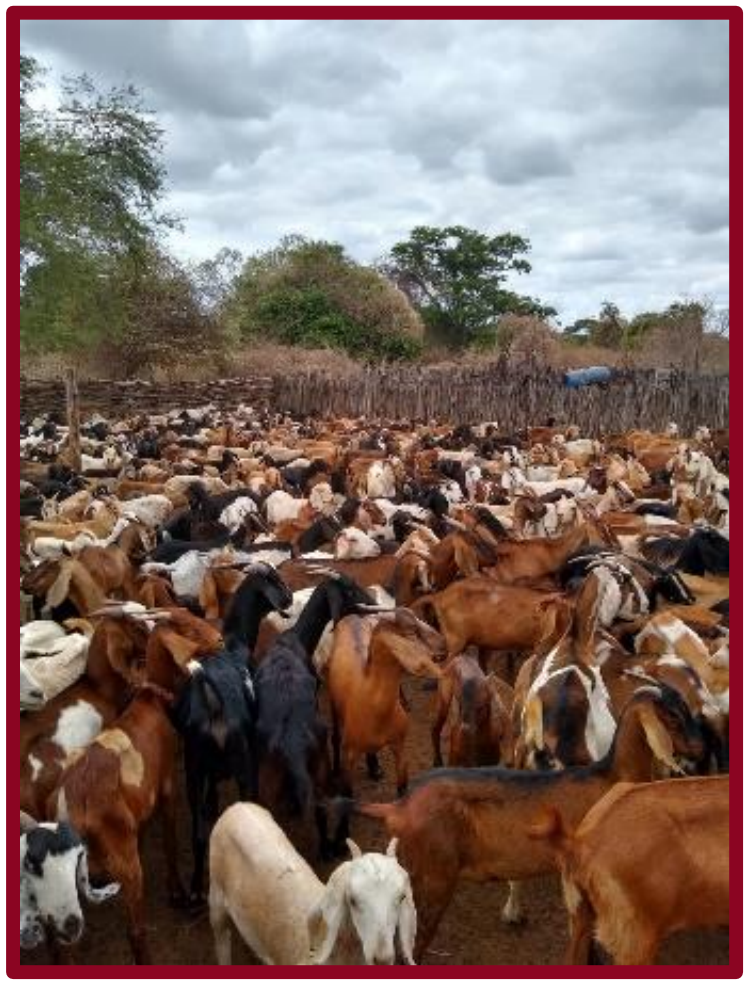

Fonte: Acervo da Família.

Foto 25 - Curral da Fazenda Lagoa das Pedras

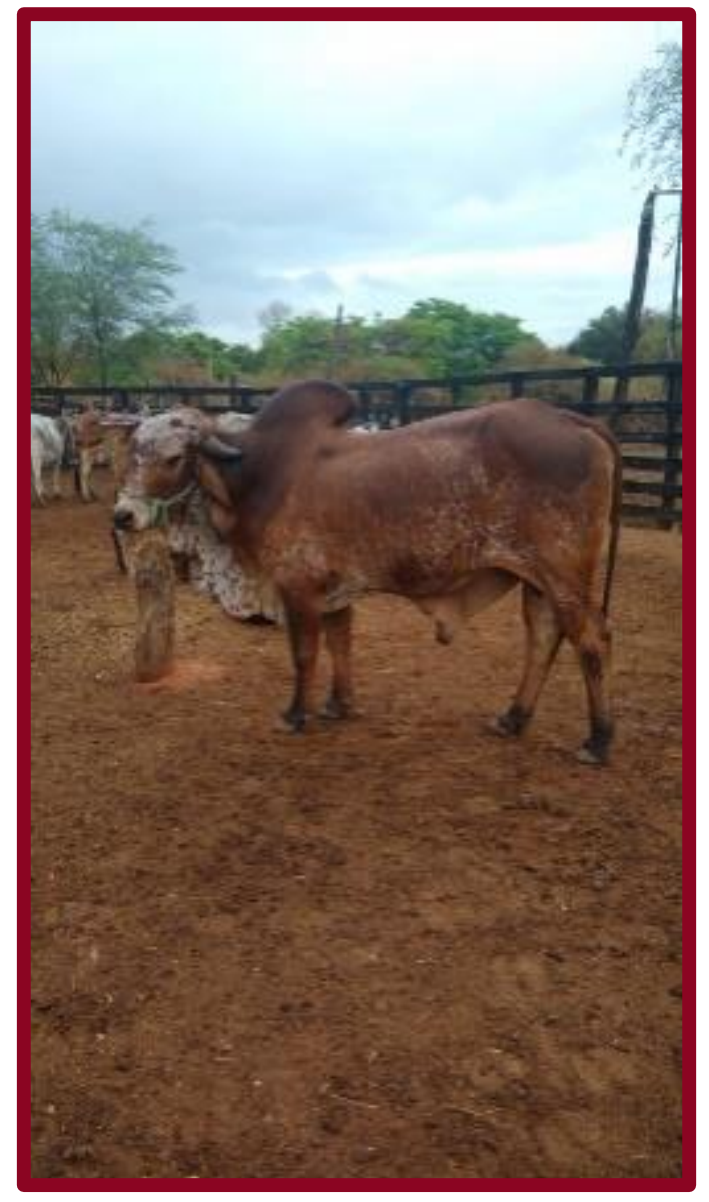

Fonte: Acervo da Família. 


\section{Hêter Fosé Macédo Rodrigues}

Genro, comandante da Marinha Mercante, casado com Ana Izabel, tem três filhos.

\subsection{O bode Melado, haja adrenalina!}

Dentre os afazeres que eu tinha na Lagoa das Pedras, se é que realmente um afazer para um menino de 14 anos é obrigação, e, nesse caso, era só prazer: acompanhar e ajudar Carvalho e Antônio Luiz a juntarem toda a criação, e, aqui, refirome, principalmente, aos caprinos.

Fazia-se isso pelo menos uma vez por mês, juntando todos os caprinos da Lagoa das Pedras no "chiqueiro dos bodes" que ficava em frente à casa grande. Essa demanda levava o dia todo ou até mesmo dois dias, pois a intenção era juntar todos os "bodes"(entenda-se daqui para frente como caprinos de maneira geral) que comiam pelo cercado do paraíso, Merejo, Pedra da Onça, nos morros, do Canto, Muquém, nas Lajes, pelas extremas com o Catingueiro, Mucunã e uma parte da Carnaúba. Enfim, procuravam-se os "bodes" por todos os lugares e também em terras alheias, pois para caprinos, não há cerca que os segurem. Diz-se até que se você desejar criar seus "bodes" em sua propriedade realmente, combine com seu vizinho, para que inicialmente ele receba os seus e você os dele, pois certamente os seus, morando na propriedade do vizinho, passarão a extrema dele e virão comer em suas próprias terras e vice-versa com seu vizinho.

Certo dia, indo para esse manejo com Carvalho, Manoel Rodrigues e eu, lá pelo Merejo, depois de andar muito atrás de criação, de já ter levado vários deles para o chiqueiro, tivemos notícia por meio de um menino de nome Suá, aproximadamente da nossa idade, acredito que uns 14 anos, que tinha visto um grande pai de chiqueiro, de cor "Melado", que estava rodando sua casa atrás de suas cabras e, de fato, Carvalho já tinha sentido a falta do tal bode Melado. 
Fizemos várias viagens ao Merejo, Cercado do Paraíso, atrás desse bode, pois Suá, insistentemente dizia ter visto o tal bode pelas bandas de lá, perto do lajeiro tal e que tinha visto rastro do bode, cabelo do bode na cerca, etc. Carvalho, que era mais experiente na região e conhecia os moradores locais, sabendo da fama de "Xicó" do Suá, acredito que dava um desconto de $50 \%$.

Por fim e aqui me falha a memória, o bode foi preso e vou colocar aqui os créditos dessa prisão para o Suá, embora não tenha a certeza, mas o fato é que fomos decretados a buscar o bode, porém, ele estava com algumas cabras e eu achava que iria ser fácil. Levamos máscaras, chocalho para colocar no Melado.

Carvalho me alertou que se eu nunca tivesse visto um veado correndo dentro dos matos, que eu aproveitasse, pois a cena seria muito parecida e não deu outra. O bode Melado foi solto com as cabras para facilitar a lida, mas seu instinto selvagem agiu rapidamente, separando-se dos outros animais, tomando um rumo diferente do desejado por nós, que era ir no sentido do chiqueiro da fazenda.

Como falei, o bode partiu "no rumo de cima", totalmente oposto ao da Lagoa das Pedras. Aí começaram os atalhos por nós. O bicho subiu tanto no rumo oposto, que cheguei, a um dado momento, ficar "ariado" (alheado).

Depois de muita luta, cipó no lombo e no rosto, finalmente conseguimos sair com o bode no sentido certo. Diga-se de passagem, que o bode também tomou muita bordoada em pedras e tronco de paus, devido à carreira e ao fato de ainda estar mascarado, enxergando apenas um metro a sua frente, mas sua resistência era bem maior do que a nossa. É claro!

Era sempre assim, inicialmente, bem difícil, mas depois que a criação pegava o sentido certo, mesmo ainda correndo pelas veredas (nunca na estrada), já aliviava um pouco. O bode Melado fez o trajeto em uma só carreira do Merejo até o Riacho do Calixto. Já na junção com a estrada que vai para o Catingueiro (fazenda vizinha) e sempre querendo voltar, mas nossos gritos e atalhos o impedia.

Depois da passagem do riacho, tinham uns lajeiros com xique-xique e, nesses lajeiros, era de costume juntar água da chuva em alguns poços existentes. Foi quando o Melado, sem perceber, caiu dentro de um desses poços d'água. 
Já eram umas 15 horas, o sol quente e a água mais ainda. O bode, que estava com o corpo suado da carreira inigualável e com a adrenalina nas alturas, sentiu o "baque" do banho, um choque térmico imenso, perdendo um pouco as forças, porém, não desistiu e saltou fora do poço. Mesmo assim, o Melado se jogou para cima de uma touceira de xique-xique, onde os espinhos lhe castigaram todo o corpo. Pois é, juntando as espinhadas com o choque térmico, Melado ficou com as energias esgotadas ao ponto que, pela primeira vez, conseguimos chegar perto dele, pegá-lo e tocá-lo.

Melado já não era mais o mesmo, já não queria mais correr, só caminhar e com dificuldade. Resolvemos, então, tirar a máscara e o chocalho, para que ele conseguisse finalizar sua jornada. Após isso, conseguimos chegar à Lagoa das Pedras, empurrando o bicho pelos quartos (traseira). Ao chegar ao terreiro, antes de adentrar no chiqueiro, Melado deu seu último suspiro e morreu. Morreu enfezado do estresse que passou, sem mais nenhuma energia, nem para respirar.

Estava lá o Viana e foi logo dizendo que não dava para aproveitar a carne pela forma que o bode morreu e que somente o couro poderia ser aproveitado. Tiraram o couro e, antes de jogarem a carcaça fresca fora, eu, Carvalho e Manoel Rodrigues, simulamos um ponto de venda, ou seja, um frigorífico, retalhamos o pobre do Melado em partes para venda, oferecendo a quem passava na "estrada real", como dizia a tia Estrelinha, ou seja, ficamos brincando de açougue.

Nossa brincadeira chegou aos ouvidos da tia Estrelinha que, imediatamente, veio para a calçada e de lá mesmo sem descer os batentes, já nos deu um carão, passou o "rela” e disse: “os três já pra dentro, seus cabritos! Direto pro banho. Quem já se viu brincar com uma coisa dessa, ainda mais com um bicho que morreu enfezado, pra dentro agora!!!"

Corremos para dentro da mesma forma que Melado correu quando descia o morro do Merejo e fomos direto para o banho. Depois, tia Estrelinha passou álcool na gente, terminando o carão e alegou que a brincadeira com a morte do bode poderia deixar possíveis consequências sanitárias em nosso corpo. 
Esse fato foi marcante em minha vida, pela adrenalina vivida em todos os momentos, desde a saída da Lagoa das Pedras, com rapadura no bolso para comer com folha do pé de umbu, chegar ao Merejo, trazer o Melado para casa, brincar de açougue, carão a "rodo" e depois afago. Não esqueço dessa façanha! 


\section{Qebastião Pereira e Qrouza Qleãa (Pabah)}

Genro, advogado, tem duas filhas: Marianna e Julianna.

\subsection{Cilada de cunhado}

A primeira vez que fui à Lagoa das Pedras foi em 1982, quando conheci a Dalva. João de Deus (irmão da Dalva), achando que eu era da capital, pois na verdade fui criado na Fazenda Várzea da Ema, município de Canindé, morando depois em um sítio em Aratuba, ou seja, um garoto esperto que morou do sertão à Serra de Baturité. Isso ele não sabia.

Fez-me montar num cavalo corredor, tudo isso para "frescar" (fazer brincadeiras) com minha cara e me fazer passar vergonha em frente à plateia, pois a calçada da casa da fazenda estava cheia de familiares e moradores, pensando ele, que eu era besta e mole.

Montei no cavalo, o bicho disparou comigo e fui longe. Voltei na mesma disparada, risquei o cavalo no terreiro bem pertinho da calçada da casa, desci e disse: “o cavalinho até que é bom!” Para a decepção do João, que pensou que o cavalo iria me derrubar. Por isso, gente, é sempre bom ficar atento às ciladas dos cunhadinhos metidos a engraçados. 


\section{Ossianubia Gaxwalha Alencase}

Neta, advogada, casada com Marcelo, tem duas filhas.

\subsection{Já chamando a vovó de mãe}

Trinta dias? Nada! Minhas férias e de meus irmãos: Ossianeide, Alencar, Carvalho e Ossian Filho, eram em média sessenta com meus avós, isso quando minha mãe não viajava para fora do Brasil. Uma vez ficamos de dezembro a fevereiro, pois as aulas só começavam em março, então, ela aproveitava e fazia aquela viagem dos sonhos com o papai.

Eles iam nos deixar na fazenda para fazer nossa adaptação, até porque, passávamos um ano sem vir, pois a gente morava em Maceió-AL. Era bem longe!

Depois de uma semana já adaptados, mamãe começava a dar todas as diretrizes para a vovó, como se ela não tivesse criado 10 filhos. Vovó, mandava logo chamar uma equipe de moradoras que seriam nossas babás, uma delas era a tia Ferreira, de 65 anos, cega de um alho (perdeu o olho soltando fogos), ou seja, a vovó ficaria muito bem assessorada! De fato, minha avó terceirizaria tudo, tendo em vista a grande labuta da casa, fazenda e o próprio físico que não permitiria correr atrás de menino.

No dia da saída dos meus pais para Maceió, para de lá viajarem, foi aquele rebuliço, mamãe dando todas as coordenadas para a vovó. Que coragem! Lembro-me de uma lista de remédio que ela deixava pregada no quarto da vovó para todos os tipos de ocorrência.

Vovó, muito sábia, ouvia tudo, sempre dando entender que ia fazer daquele jeitinho. Que nada! Quando mamãe, finalmente, ia embora, vovó olhava para a lista e dizia: "não vou nem olhar isso, se eles adoecerem, vão tomar mesmo é os meus remédios, criei foi dez filhos". E era desse jeito; banha de galinha quente com alho era um dos remédios. 
Haviam-se passado dois meses e eu já chamava minha avó de mãe, foi quando vovó se preocupou e escreveu para Maceió, pedindo que se comunicassem e dissessem que estavam na hora de voltarem para virem nos pegar, pois eu já estava chamando-a de mamãe. Que povo para ter coragem! Ficar com cinco crianças no sertão, sem qualquer comunicação. Outros tempos! Só sei que era bom demais!

\subsection{Inspeção noturna}

Sempre que estávamos na Fazenda Lagoa das Pedras, minha mãe chamava tia Ferreira para ficar. Ela deixava o tio Ferreira e dormia na casa da fazenda com a gente. Elas se queriam muito bem.

Como nossa família era grande, vovó nos colocava para dormir na maior sala da casa, chamada de "varanda", lá cabiam sete redes, ou seja, uma fila de redes, a quantidade de pessoas da minha família.

Minha mãe sempre muito limpa, todas as noites, antes de dormir, ela e tia Ferreira olhavam quem estava "xixiado" (urinado) para trocar a roupa, etc. Nesta noite, todos dormindo, inclusive meu papai, minha mãe pediu à tia Ferreira que verificasse se havia algum de nós molhado.

Tia Ferreira, de pronto, começou a fazer a averiguação, que consistia em nos apalpar, só que em umas das redes estava meu pai, aí, já viu... tia Ferreira apalpou meu pai em local não adequado, papai acordou, é claro, e disse: “Dona Ferreira, sou eu." Aí menino, foi aquele choro! Mamãe não sabia o que fazer e pediu mil desculpas a ela pelo ocorrido e nunca mais ela participou dessa inspeção.

\subsection{A mulher era braba!}

Uma das vezes que estava na fazenda de férias, os tios e os rapazes tinham ido a uma viagem curta ao Piauí para resolver uns probleminhas rotineiros, próprios da labuta.

Dormimos essa noite, eu, vovó, Liduína e Edmilson, da minha idade (adolescente), mas era homem. Estávamos garantidas. Nos recolhemos cedo, após o 
tradicional terço. De madrugada, escutamos o Jagunço latindo muito e um barulho das criações no chiqueiro. Vovó, muito destemida, levantou-se e foi em direção à porta da frente da casa, encontrou Edmilson “aperriado" (aperreado, nervoso), sem saber o que fazer. “Coitado! Acalme-se meu filho!” Disse ela. Abriu a porta e viu uma picape com alguns homens roubando as ovelhas, então, ela gritou dizendo que eles deixassem as ovelhas e fossem roubar os peixes no açude. Os ladrões saíram tão apressados que deixaram de levar três das ovelhas que tinham pegado. Ora, uma mulher abrir a porta de casa, de madrugada e dá um grito nos ladrões, não é uma cena que se vê todo dia, mesmo naquela época. Foi o assunto mais comentado no dia seguinte.

\subsection{Babá idosa destituída do cargo}

Meu irmão, Manoel Carvalho, era uma criança muito levada. Vovó Estrelinha tinha uma pessoa exclusiva só para ficar "na cola" dele. E essa pessoinha era a tia Francisca. Imagine só! Um descompasso! Carvalho com a energia lá em cima e tia Ferreira de quase 70 anos com a energia nem tanto assim.

Ela passava o dia tentando ver por onde ele estava, na realidade, só ver de longe mesmo. Num desses belos dias, vovó perguntou: “Chica, por onde anda o Carvalinho?" Aí, menino, ela se "aperriou” (aperreou) e começou a perguntar a um e a outro, ou seja, se alguém tinha visto o menino.

Foi quando alguém avisou para ela que ele estava andando em cima da casa. Foi um aperreio só. Vovó comentou: “Chica, você não tem mais condição de cuidar desse menino". Óbvio! A partir daquele dia, tia Ferreira foi destituída do cargo para o bem de todos, principalmente dela.

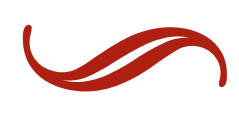




\section{Ghxistiane Gavealho Maurãa de Freitas Guimaxães}

Neta, socióloga, casada com Dalton Guimarães, tem uma filha.

\subsection{Momentos inesquecíveis da minha infância}

Primeiro dia de minhas férias escolares, lá vou eu para a fazenda de meus avós, com minha malinha de mão, repleta de lembrancinhas para os meus afilhados de apresentação e alguns lanchinhos que mamãe mandava para entregar à vovó Estrelinha. O ônibus partia às 13h30min, da Empresa Gontijo, rumo à Lagoa das Pedras. Geralmente, meu companheiro de viagem era o vovô Manoelzinho ou o tio João, pois a gente não podia viajar desacompanhada.

Vovô carregava sua charmosa malinha de couro e sempre fumando seu cigarrinho artesanal, feito na "papilina" (papel para fazer cigarro). Tinha um sorriso bonito e amoroso, distribuía simpatia e elegância por onde passava. Dizia: "vamos lá, minha nega". Não esqueço daquela fisionomia afetuosa e, ao mesmo tempo, firme e cheia de atitude.

A primeira parada do ônibus se dava em Novo Oriente, porém, não saíamos do ônibus. Logo depois de uma hora, mais ou menos, chegávamos ao Monteiro, nosso ponto de descida. Tinha sempre alguém nos esperando para ajudar com a bagagem, normalmente quem vinha nos esperar era o Edmilson (filho adotivo).

Logo na chegada à casa da fazenda, éramos recepcionados por alguns moradores que ali estavam sentados nos bancos de madeiras, distribuídos na calçada. Como nossa chegada sempre era no finalzinho de tarde, sempre havia alguns na calçada, puxando uma prosa, um verdadeiro ponto de encontro. Enquanto os outros, saíam para pegar o gado no pasto.

Ao entrar em casa, lá estava a vovó Estrelinha com suas assessoras de cozinha. Naquele dia, era a Bela preparando aquele jantar, caseiro e delicioso. Eu adorava aquele arroz integral que vinha das rendas do Piauí, com carne batida e 
batatinha. Este era meu menu preferido. Havia ainda muitas outras iguarias que vovó fazia, tudo para nos satisfazer.

Por volta das 17 horas, começava o movimento de abastecer as lamparinas e os lampiões com querosene, pois, naquela época, não havia energia elétrica e, aí, era um pulo para o jantar. Jantávamos e conversávamos tanto sobre os acontecimentos do dia, que vovó precisava mandar a gente sair da mesa para colocar o jantar para os rapazes que trabalhavam e moravam com eles.

Depois da janta, era de costume rezarmos o terço no quarto do santuário. Um momento sempre muito fervoroso de fé da vovó. Também em algumas partes do terço, chegava a ser hilário, pois, enquanto a vovó rezava, o restante já respondia quase de imediato o Pai Nosso e as Ave-Marias, mas era um momento lindo, todos rezavam e louvavam com muita fé e, no final do terço, tinham os lindos cânticos! Após o terço, a gente sentava na calçada para apreciar o céu estrelado e ria muito, pois naquele cantinho, não faltavam alegria e acolhimento.

Antes de nos recolhermos para dormir, tinha a deliciosa coalhada, todos novamente à mesa grande da sala para esse momento da ceia. Eu gostava de dormir no quarto da "Iaiá" (irmã do vovô), pois morria de medo de morcegos e diziam que lá era mais protegido, tudo invenção do tio João, que nos dizia que tinha feito uma limpeza no telhado e não havia mais morcego. Que nada! Quando acordava de madrugada, lá estavam eles sobrevoando minha rede. Que pânico grande! Mas, o cansaço grande do dia me fazia adormecer.

Ao amanhecer, fazia questão de tomar o leite mugido. Vovó mandava trazer um copo cheio de leite, diretamente do curral, uma delícia! O leite era tão forte que, ao tomar, eu caía no sono de novo.

E o bolo de milho, cuscuz com leite que vovó separava, individualmente, em cada pratinho, como eram saborosos! Depois disso, o que não faltava era diversão pela fazenda. O piquenique embaixo das oiticicas, onde preparávamos nossa comidinha, sempre em companhia das minhas amigas: Iracema, Cosma, Damiana, Liduína, Rosinha, Aninha e Raimundinha. Também havia a Dona Raimunda do Branco que juntava cabacinhas e trazia para a gente brincar. 
Nossa companheira, nos momentos de doenças, gripes, etc., era a tia Ferreira. Vovó, muito cuidadosa, nos deixava em repouso absoluto. Além dos lambedores de malva e mel, também tinha a tão temida colher de manteiga com alho, que tomávamos para tosse. E não tinha conversa não! Tomávamos mesmo, ela contava até três e dizia: Amém! Pois não é que amanhecíamos bons, remédio dado com fé e amor.

Lembro-me que durante umas férias, tive, simplesmente, papeira (caxumba). Aí, meu filho, o repouso foi absoluto, quase um cárcere privado! Mas, uma vez, tia Ferreira foi minha cuidadora e tinha uma coisa que elas diziam: "se pular, fizer movimento, extravagância, a papeira desce". Faziam medo mesmo, para a gente ficar quieto.

A vovó era uma figura! Ela dizia: “hoje, é se aquietar, pois passou a noite toda no "tefo tefo", ou seja, tossindo. E haja Vick!

Não esqueço também um móvel de madeira com portinha de vidro que havia no corredor, onde a vovó guardava os bombons comprados na bodega do Monteiro. Como era bom! E não faltava viu?! Vovô Manoelzinho sempre andava com bombons no bolso. Saudável? Muito, pois era puro afeto, nunca fez mal.

E o bolo "espera marido", nome e receita exclusiva da vovó. Muitas vezes, encontrávamos casquinhas de ovos na massa, mas ninguém se importava com isso, até porque era um bolo bom. Tinham também as rosquinhas, destas, sinto até o cheirinho, preparadas exclusivamente para a criançada. Percebo que estou agora mesmo viajando nas delícias de nossa vozinha, tão moderna e jovial.

A Rádio Educadora era audiência certa! O rádio velho era ligado o dia todo. Como tive uma infância divertida! O vovô insistia para que eu ficasse morando com eles na Lagoa das Pedras e estudar no colégio da "Didida". Eu achava genial aquela proposta, porém, papai jamais deixaria. Eles falavam aquilo em tom de brincadeira, mas amava aquela ideia.

Cavalgava no cavalinho do vovô, de nome "Retrato". Retrato era branquinho e bem mansinho. Íamos para o Calixto, Carnaúba, passeios inesquecíveis!

Tinha uma brincadeira que adorávamos, era procurar ovos das galinhas e dos capotes (galinha da Angola). Vovó tinha todo interesse que encontrássemos, nos 
incentivava bastante, nos dando prêmios, os mais variados. Esperta! Tudo, até as obrigações viravam brincadeiras.

E o banho de água de pote, um gelo! Acho que é por isso que até hoje gosto de banho frio. Os sabonetes eram o Lux e o Alma de Flores, as toalhas cheirosas, tiradas do fundo do baú.

Outra diversão grande era ir para a feira de Novo Oriente. Vovô me dava um trocadinho, eu comprava umas "bijus" (beiju) bem exageradas e umas lembrancinhas para meus afilhados.

Chegado o dia da volta para Crateús. Oh! Tristeza! Acordava quase de madrugada para pegar o ônibus, às 5 horas da madrugada, com certeza acompanhada. Às vezes, até mesmo com o vovô, que ia nos deixar em casa. Enfim, tinha acabado a brincadeira e era hora de retornar às aulas. Quando vovó não ia deixar, sempre me dava um trocadinho para a viagem, eu achava o máximo.

Posso dizer que fui uma privilegiada pelo convívio tão intenso e amoroso que tive com meus avós maternos, naquele santuário que eles construíram com alicerce de amor, união, compaixão e felicidade, chamada Lagoa das Pedras. Depois da partida deles, me ausentei, mas tenho certeza que a energia daquele lugar continua e será eterna. Saudades! 


\section{Qhandra Sharia Oimenes Bavealtho}

Nora, professora, casada com Antônio Luiz, tem duas filhas.

\subsection{Seu Manoelzim e Dona Estrelinha}

Desde pequena, eu ouvia falar na Fazenda Lagoa das Pedras do Senhor "Manoelzim" de Carvalho. Ele foi um dos primeiros hóspedes do hotel de minha avó, na cidade de Novo Oriente. Logo depois, tornaram-se muito amigos. Dessa forma, ouvia muitas da sua conduta de honestidade, serenidade, educação e bem viver do Senhor "Manoelzim".

Infelizmente, não tive o prazer de conviver com ele, pois vim conhecer a Fazenda Lagoa das Pedras já em sua despedida desse mundo, diga-se de passagem, o terreiro da casa estava lotado de familiares, moradores e amigos de todos os lugares. Ali, tive certeza de que tudo que ouvia falar sobre ele e sua esposa, Dona Estrelinha, era verdadeiro.

Os relatos que ouvi e ouço até hoje (por ser nora deles) foram e são relatos de pessoas que viveram para servir ao próximo, com suas maneiras determinadas, positivas, autênticas, mas estavam sempre ao lado dos menos favorecidos para atendêlos no que fosse possível.

Quando cheguei à Família Carvalho, pude conviver com Dona Estrelinha por quase dois anos. Uma senhora firme, mas muito querida e respeitada por todos da redondeza. Estive presente em muitos momentos que os moradores vinham procurála para aconselhá-los ou mesmo só para pedir sua bênção. Sempre os recebia com uma palavra de conforto, afago, um cafezinho e um pedaço de queijo. Para as crianças, pão e rapadura. Dava para sentir, no olhar das pessoas que a procuravam, a satisfação e o coração leve.

Sou de uma família católica e religiosa, mas o tempo em que convivi com ela me trouxe muitas lições de religiosidade (até hoje rezo umas orações que ela me ensinou); amor ao próximo, por meio dos cuidados e, principalmente, a capacidade de 
aprendermos a abdicarmos e abrirmos mão de muitas coisas para vivermos um casamento de amor e criarmos os filhos nesse ambiente fraterno.

Nunca esqueci quando ela me dizia que deixou a cidade de Independência para viver na Lagoa das Pedras com o maior marido que Deus tinha escolhido para ela e ainda que passou cinco anos sem sair da fazenda quando os filhos eram pequenos, ressaltando, ainda, que não era nenhum sacrifício para ela cuidar dos filhos. Era um grande prazer! E olhe, que pelo que ouvia falar, a equipe que ela comandava era grande.

Ela gostava muito de se sentar ao lado da janela do quarto (anexo ao da Iaiá), para apreciar o pôr do sol, e dizia: "não existe pôr do sol mais belo e mais bonito do que o da minha janela". Por isso, era uma pessoa feliz. Suas raízes, seus ensinamentos, seu amor e sua fraternidade ficaram plantadas na Fazenda Lagoa das Pedras, onde todos nós sentimos sua presença espiritual ao chegarmos lá. 


\section{Aingela Maria MSachado Faswaltho}

Nora, servidora pública, casada com João de Deus, tem três filhas.

\subsection{Convivendo com meu sogro e minha sogra}

Casei com João de Deus em 1981. Foi quando comecei a frequentar a Fazenda Lagoa das Pedras, onde moravam seus país: Manoel Carvalho e Maria Estrela, casal de muito respeito que me tinha muita atenção e apreço.

Lá vivenciei muitos momentos bons e, convivendo com eles, aprendi muitos costumes. Lembro que todas as noites rezávamos o terço com todos da casa, e Dona Estrelinha rezava para que Deus nos livrasse do mal e nos desse saúde, paz e paciência.

Havia uma moradora, já idosa, de nome Francisca Ferreira, que era muito engraçada e sempre dizia: “Dona Estrelinha, Deus me livre de rezar para Deus me dar paciência, porque senão o povo me mata."

Também conheci lá, Dona Maria José Coutinho (Mãe Zezé), irmã da minha sogra. Pessoa franca, inteligente, amável, comunicativa e também muito engraçada. Gostava muito dela, ela demonstrava muito carinho por mim.

Logo que Dona Estrelinha faleceu, tia Mazé passou um tempo por lá e sempre a gente ia durante os finais de semana. Como era de costume, à tardinha, sempre sentávamos na calçada para ver o movimento, como diziam elas.

Tia Mazé, quando entrava, lembro-me que dizia: “Ângela, venha logo pegar sua lamparina, papel e fósforo que o tempo do conforto acabou, se você estiver pensando que vou lhe dar tudo na mão como a Estrelinha, está muito enganada."

Outra coisa que não esqueço é que eu chegava de Crateús, pois na maioria das vezes vinha só, porque João já estava lá; antes mesmo de chegar na casa, Seu Manoelzinho sempre ia ao nosso encontro para me receber, isso me cativou muito, ele era muito gentil e bondoso. Tia Mazé, muito "mangadeira" (caçoadora), dizia: 
“Ângela, olha aí, o João nem vai te receber, mas o "Manoelzim" vai." E, aí, começava a risadaria.

Tia Ferreira também era outra "figura", eu falava para ela ir a casa ver o esposo, "Seu Ferreira" e ela me falava: “Ângela, eu já deixei tudo arrumado, o 'véi' já ficou até embolachado (lanchado), agora só vou quando Danúbia chegar que abrir as "urnas" (bagagem)". Ela, doida por presentes surpresas.

São muitas as recordações que guardo da época que passei na Fazenda Lagoa das Pedras. Agora, digo como Dona Estrelinha: “Oh! Planeta forte!” 


\section{Hantência Maria OGimenes Garualho}

Neta, acadêmica de Odontologia, filha de Antônio Luiz, solteira.

\subsection{Pé de umbu, nosso restaurante}

Lembro-me com muita saudade da minha infância vivida na fazenda de meus avós.

Eram muitas as brincadeiras, não esqueço das brincadeiras no pé de umbu, árvore centenária, dos banhos de açudes, das chuvas com direito a banho e brincadeiras na lama, bem fria!

Na brincadeira de casinha, simulávamos uma família tradicional: pai, mãe e filhos e, aí, tínhamos que obrigar os primos a fazerem o papel de pai da família, era uma comédia!

Pegávamos escondido, na casa da fazenda, mantimentos para o almoço e lavávamos para o pé de umbu. Branca, mesmo com uma certa resistência, acabava nos dando um pouco de arroz, feijão, alguns ovos e uma panela. Recordo que a comida, mesmo com muito esforço, nunca ficava boa, mas comíamos do mesmo jeito.

Outra que brincávamos e que gostávamos muito era a brincadeira de restaurante. Era o "restaurante Família Carvalho". Era bom demais!

Aqui é apenas um pequeno relance das minhas lembranças, que ficarão guardadas para sempre no meu coração e que, ao lembrar, dá aquele aperto no peito de tanta saudade.

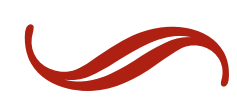




\section{Isabel Gomes de Gaxwaltho}

Neta mais nova, estudante, filha de Carvalho, solteira.

\subsection{Eu, meu pai e a lagoa...}

Desde quando ainda era bebê, já frequentava a Lagoa, pois meu pai sempre teve duas casas, a nossa casa de Quiterianópolis e a casa da Lagoa.

Até hoje o acompanho nos finais de semana e feriados, até mesmo quando minha mãe não pode ir, por um motivo ou por outro, eu vou com ele; somos bem amigos e companheiros! Na Lagoa, sinto-me em casa.

Não conheci meus avós, mas é como se tivesse conhecido, pois a casa da Lagoa é como um museu vivo, cheio de história: os objetos, os moradores, as pessoas que conheceram, eles me passam toda a história real, consigo até ver as cenas que se passaram lá.

A Lagoa é vida! São muitas coisas acontecendo ao mesmo tempo, precisamos sempre estar atentos para não perdermos os acontecimentos, as oportunidades, os movimentos e passeios que acontecem a qualquer hora na rotina diária.

Ando a cavalo, de bicicleta; hoje, mais de moto. Vou à casa do tio Virgílio, à Carnaúba do "Padrim" João e Mucunã da madrinha Aurélia.

Acompanhei com ela toda a construção do Rancho Mucunã, foi muito legal. Que movimento alto! Não faltava novidade. Foi um ano e meio construindo. Sempre que ela vinha, era uma bagagem imensa! Desmantelo grande! Bagulho que não acabava mais. Pois não é que ficou bem legal!

Gosto dos movimentos que ela faz lá, já fez Natal, São João, até meu aniversário de 15 anos surpresa foi feito lá, só mesmo para a família.

Fazemos também encontros à noite, à luz de fogueira. Meu pai diz que o Rancho Mucunã é a Jeri do Sertão, por causa da decoração rústica e criativa. 
Hoje, quando madrinha Aurélia vai para a fazenda, fica entre a casa da Lagoa e a do Rancho, depende da movimentação do dia. Diz ela que agora tem duas casas. É a besta! Muitas vezes, ficamos sozinhas na Mucunã, eu, na rede do alpendre escutando música ao celular, e ela, naquele para lá e para cá. Algumas vezes, vou embora, ela fica lá sozinha sem problema! Depois, venho pegá-la de moto. Ela gosta demais de lá! Impressionante!

Gosto da Lagoa por ela ser exatamente como é: aquela simplicidade, liberdade, oportunidades instantâneas de passeios, tudo sem planejamento e, ainda, com os movimentos da política, agora digo como a vovó Estrelinha: “Oh! Planeta forte!"

Na Lagoa, o dia é como se fosse uma página de um livro em branco, que durante o dia, escrevemos vivenciando os momentos. Cada dia é uma história diferente.

Tenho muitos amigos de infância, como também aqueles os quais conquisto no dia a dia. Tenho também alguns afilhados. Conheço todo mundo lá e gosto de todos! Sempre que meu pai quer saber o parentesco de alguém, pergunta a mim, ele diz que eu sei quem é todo mundo.

Sempre auxilio meu pai no que for preciso. Lá não tem essa história de que determinada tarefa é de homem ou de mulher, faz-se o que é preciso fazer e pronto. Meu pai faz de tudo, das compras para a casa da fazenda ao corte de lenha à machado para o fogão; até cerca ele faz, não tem isso não!

Percebo que ele é bem feliz lá e eu também, pois ele faz realmente o que gosta. Por isso, faz com muito amor! Raramente, vejo meu pai reclamar das coisas, só do que não foi feito. Amo a Lagoa, é nosso segundo lar! 


\section{Ossianeide Gaswalho Altencas Galwãa}

Neta, administradora, filha de Danúbia, casada com Felipe Galvão, tem dois filhos.

\subsection{Cabaça d'água na cabeça, lá vai Sineide!}

Da minha infância guardo ótimas lembranças das minhas férias na Fazenda Lagoa das Pedras. Lembro que vovó Estrelinha sempre providenciava uma cabaça para mim. Adorava passar os dias carregando água da cacimba para abastecer a casa. $\mathrm{Na}$ época, não tinha energia elétrica e nem água encanada.

Recordo também das lavagens de roupas na beira do rio, no açude e nas lajes, era o dia todo fora lavando roupa. Pura diversão! Levávamos o almoço e os pedaços de rapaduras com queijo para o lanche.

Outras diversões era brincar de fazer comidinha nas panelas de barro debaixo do umbuzeiro, tomar banho de bica, plantar feijão, milho e procurar ovos de capote.

São muitas recordações: infância com pé no chão, correndo, brincando em contato com a natureza e a família.

Hoje, quando fico de férias, sempre procuro fazer turismo ecológico. Acredito que muitas dessas preferências se devem a uma infância feliz, conectada com a natureza, família e ao povo sábio, simples e valente do sertão. 


\section{Ana Oraquel Garvalho Mourã̃o}

Neta, fisioterapeuta e professora, filha de Lucimar e Mourão, casada com Léo.

\subsection{Minhas recordações}

Muitas são as memórias afetivas que trago daquele lugar muito especial, em que nossos amados avós nos acolhiam com muito amor e zelo. Minha infância foi marcada por nossos finais de semana, feriados e férias, na gloriosa fazenda.

Nossa rotina era recheada de atividades, que iniciavam muito cedo, ao nos servirem um leite quentinho, que vinha direto do curral, além do maravilhoso cuscuz de milho (a massa do milho era preparado no pilão), doces, queijos e as deliciosas refeições preparadas pela equipe de cozinheiras, sob a direção total da nossa amada avó Estrelinha.

Vovó gostava muito de ouvir rádio, que ficava, praticamente, o dia todo ligado; naquela época, funcionava a pilha. Lembro que vovó era ouvinte assídua da Rádio Educadora de Crateús, além da Rádio Globo do Rio de Janeiro. O rádio tinha o importante papel de transmitir informação e entreter, além de um meio e utilidade pública, transmitindo mensagem, recados, convites, etc. Ela também gostava muito de jogos de futebol que eram transmitidos pelo rádio, chegava a rezar para o Brasil ganhar a partida.

Vovô Manoelzinho, carinhosamente, me chamava Kekel, quanta saudade! Sempre muito solícito, manso e atencioso com seus netinhos. Tinha excelente hábito da leitura de revistas, jornais e até nossos livros de "estórias" infantis, além de bulas de remédios. Quanto às bulas, algumas vezes, nos solicitava ajuda na leitura, em virtude do tamanho das letras. Recordo-me ainda das palavras difíceis e técnicas que eu não compreendia muito bem, mas vovô ficava muito agradecido.

Vovó Estrelinha era uma avó muito atenciosa, zelosa e amiga, nos acolhia com muita alegria e amor. Tinha muito cuidado com a saúde, pois, ao menor sinal de 
algum sintoma de resfriado ou gripe, os cuidados eram redobrados com a oferta de chás de alho, limão com mel, gemada e "fundo de rede", era como ela chamava repouso.

À noite, o terço era o grande momento! Rezava o terço com muita fé e devoção e acompanhado de cânticos religiosos... "Dai-nos a benção, ó Virgem Mãe, penhor seguro do sumo bem..." Essa canção, até hoje, guardo na memória, pois vovó cantava com muito vigor.

Destaco ainda os estimados moradores da fazenda: tia Ferreira, tio Ferreira, tia Francisca Ludugera, tio Virgílio, Raimunda do Branco, Seu Branco e muitos outros. A encantadora rendeira, tia Raimunda Tenente, com sua habilidade e destreza na confecção das belas rendas de bilro, além das crianças, filhas dos moradores e as secretárias da vovó, que não eram poucas e nos faziam companhias nos banhos de rio.

Falando do rio, acredito que uma grande aventura que vivenciamos na Lagoa das Pedras foi uma travessia do rio cheio em uma boia, com muita correnteza, que foi muito bem planejado por nosso pai, tios e moradores; na certeza de uma passagem segura, e que foi um sucesso, despertando muita emoção a todos.

Minha gratidão a Deus, pelo privilégio de ter convivido com meus amados avós e moradores, que nos recebiam com tanto carinho e zelo na Fazenda Lagoa das Pedras. Ademais, guardo apenas boas recordações. 


\section{Qilvana Games Medeiros Gavwaltho}

Nora, pedagoga, casada com Carvalho, tem dois filhos.

Falar da Lagoa das Pedras...

Falo com alegria e prazer,

Pois tudo que aqui expresso,

Vem do fundo do meu coração!

\subsection{Uma ajudinha do Cupido}

Inicio essas singelas palavras com um sentimento tão profundo, de eterna gratidão a Deus, pelo dom da vida, por fazer parte de uma família tão honrada, respeitada, solidária e acolhedora.

A Lagoa das Pedras representa muito para a minha vida. Conheci coincidentemente em 1989, indo a um passeio ao Catingueiro (fazenda vizinha), com minhas primas: Flávia, Nira, Luzanir e Neí, a convite de José Vieira e Adones (filhos de Dona Aldenora). Ao passarmos na Fazenda Lagoa das Pedras, fomos muito bem recebidas por uma Senhora. Esta Senhora era a tia Mazé, que estava passando uma temporada na fazenda para a Dona Estrelinha fazer tratamento de saúde em Fortaleza.

A palestra foi boa, muito prazerosa, acompanhada de um delicioso doce de leite com queijo; era a oportunidade para muitas perguntas. Depois do lanche, nos apresentou a toda família, mostrando o painel de fotografias nas varandas da casa, citando cada um dos filhos e das filhas.

Apontou para a foto do Carvalho e disse: "Esse é solteiro e muito bonito, o nome dele é Carvalhinho; está a trabalho no estado do Maranhão. Essa foto é da formatura."

No ano seguinte, nos conhecemos pessoalmente. Não sei se foi por força do destino ou se foi por orações da tia Mazé, por se engraçar comigo. Só sei que foi um presente de Deus! O grande amor da minha vida que me presenteou com dois filhos 
lindos, Davi, o primogênito, e Isabel e, agora, tenho minha Lara, minha nora, que considero como filha e minha neta de nome Luísa.

Luísa já curte a Lagoa das Pedras; quando chega lá, se diverte com as galinhas e os pintinhos no quintal, os bezerros no curral, cabritinhos no pátio. Luísa é nosso xodó. Nossa família é nosso bem maior.

Não tive a oportunidade de conhecer meu sogro, Senhor Manoelzinho e minha sogra, Dona Estrelinha, mas confesso que sinto a presença deles muito forte nesse lugar, que considero sagrado e abençoado por Deus e Nossa Senhora.

Admiro o zelo que todos os filhos têm em conservar, preservar e dar continuidade ao que eles deixaram. Além dos bens materiais, dos bons exemplos, as atitudes, as ações de agregar, acolher com carinho cada um que chega. Os vaqueiros que passam, mesmo "fora de hora", têm rancho garantido.

Sinto-me privilegiada de morar bem pertinho da Lagoa das Pedras e ter o prazer de passar quase todos os finais de semana e feriados com minha família lá, desfrutando de companhias agradáveis, de sossego, descanso e paz. De poder caminhar ou pedalar com tranquilidade, de ter o contato com a natureza, curtir o canto dos pássaros, o rio no período chuvoso. Até mesmo no período mais quente do ano, contamos os dias esperando o final de semana para irmos para a Lagoa.

Finalizo parabenizando a idealizadora e produtora do projeto Contos da Lagoa, minha cunhada, amiga e comadre, Aurélia (Lela), pela brilhante iniciativa e pelo incentivo na produção desta relíquia de grande valia para as gerações da Família Carvalho que virão.

Ah! Lagoa das Pedras! Se tu falasses, falarias melhor do que eu, porque presenciaste e és testemunha de muitas histórias... 


\section{Ealeria: OPaisagens}

Foto 26 - Paisagem da Fazenda Lagoa das Pedras

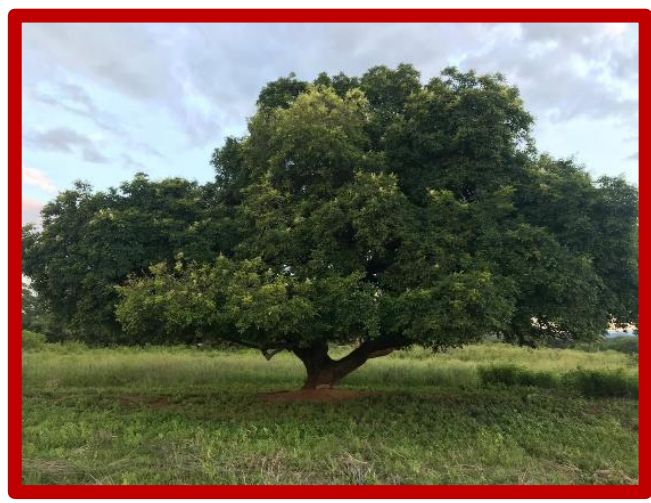

Fonte: Acervo da Família.

Foto 28 - Paisagem da Fazenda Lagoa das Pedras

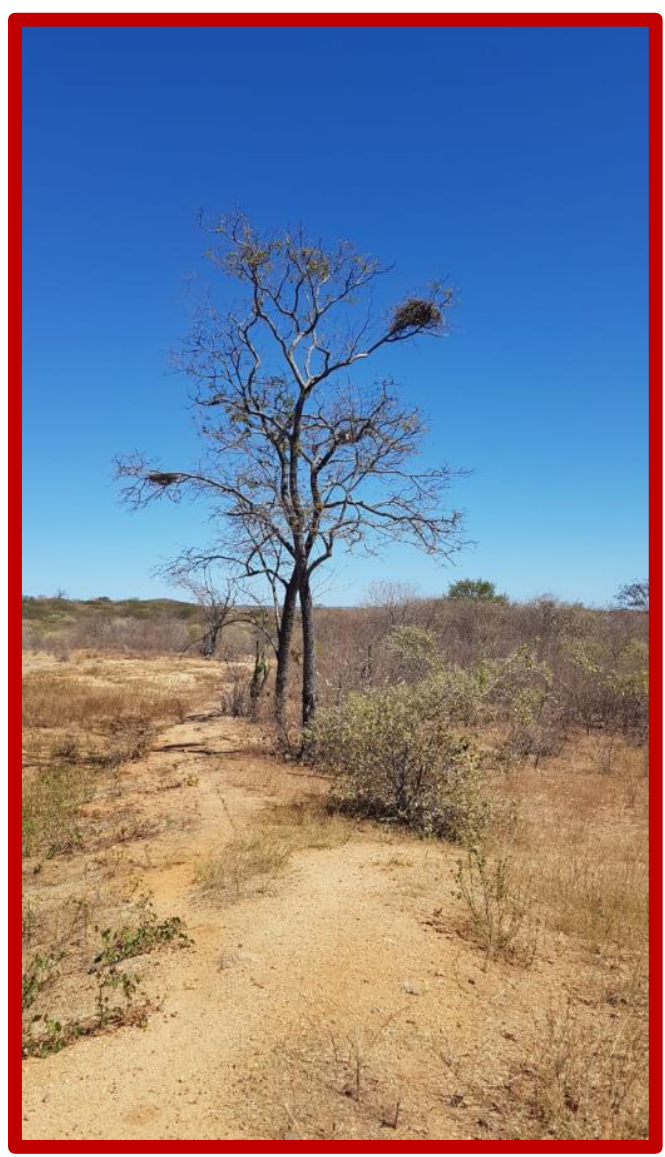

Fonte: Acervo da Família.
Foto 27 - Paisagem da Fazenda Lagoa das Pedras

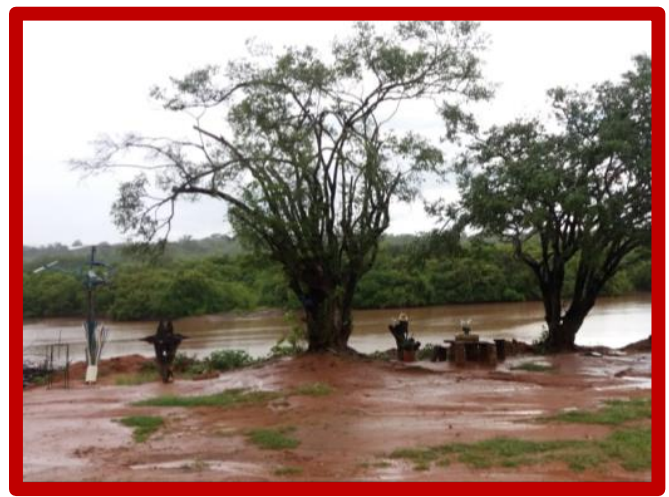

Fonte: Acervo da Família.

Foto 29 - Paisagem da Fazenda Lagoa das Pedras

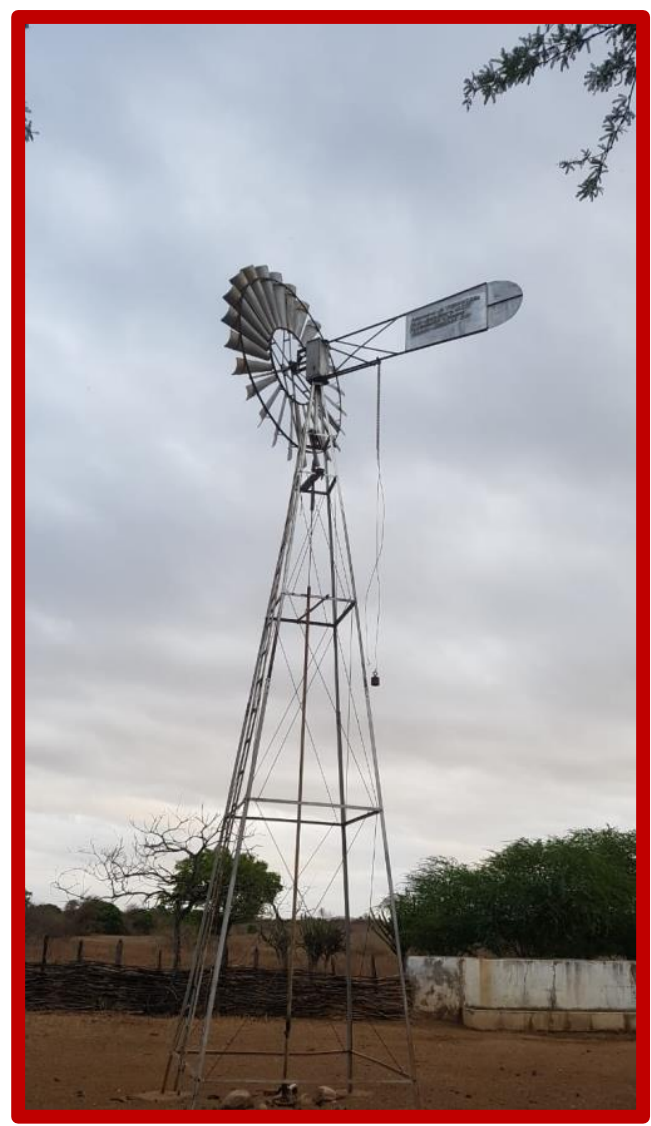

Fonte: Acervo da Família. 


\section{Galeria: OPaisagens}

Foto 30 - Paisagem da Fazenda Lagoa das Pedras

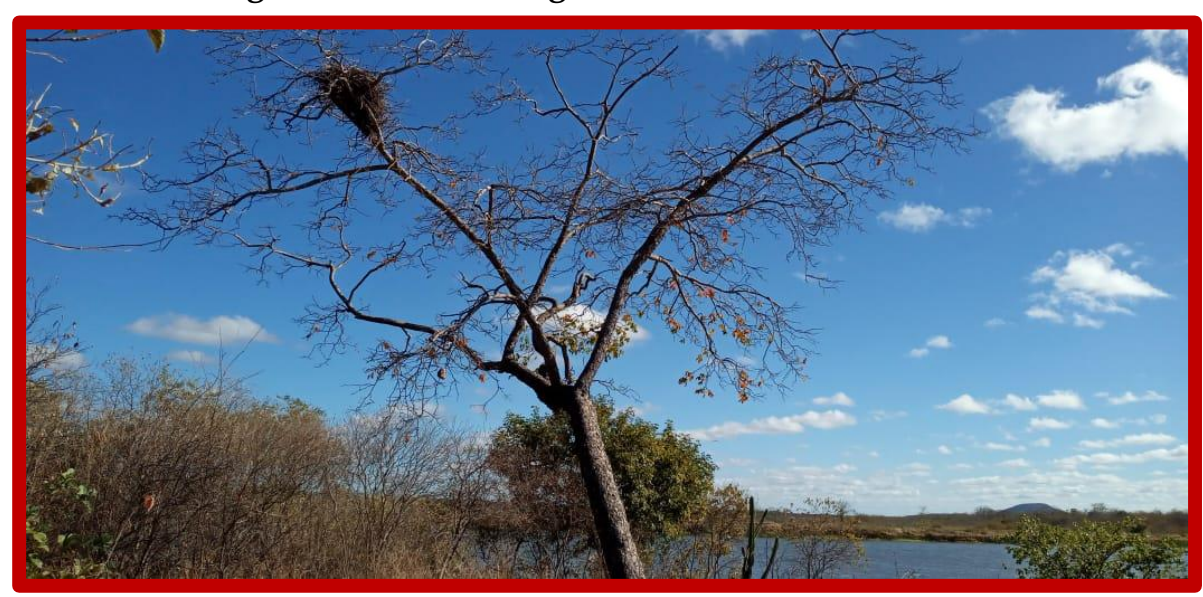

Fonte: Acervo da Família.

Foto 31 - Paisagem da Fazenda Lagoa das Pedras

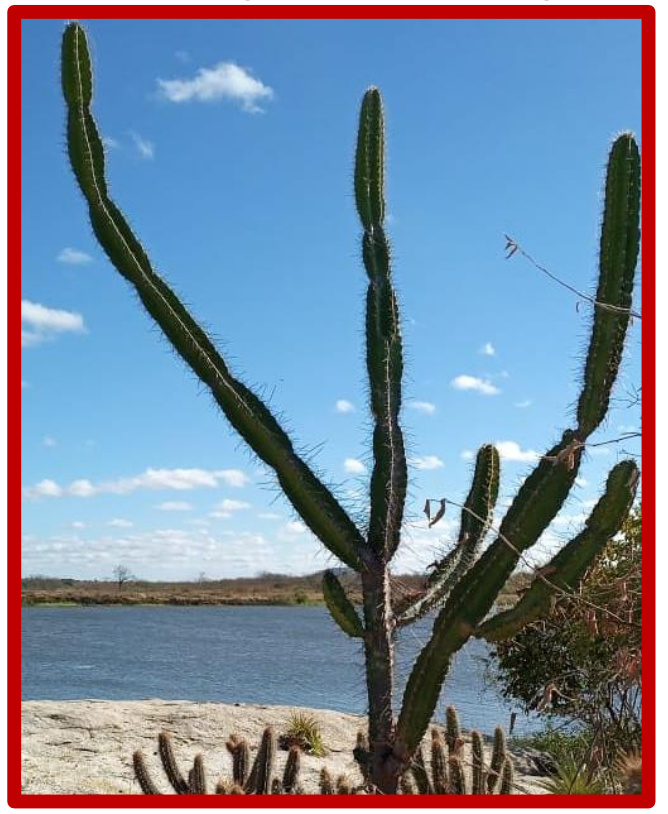

Fonte: Acervo da Família.
Foto 32 - Paisagem da Fazenda Lagoa das Pedras

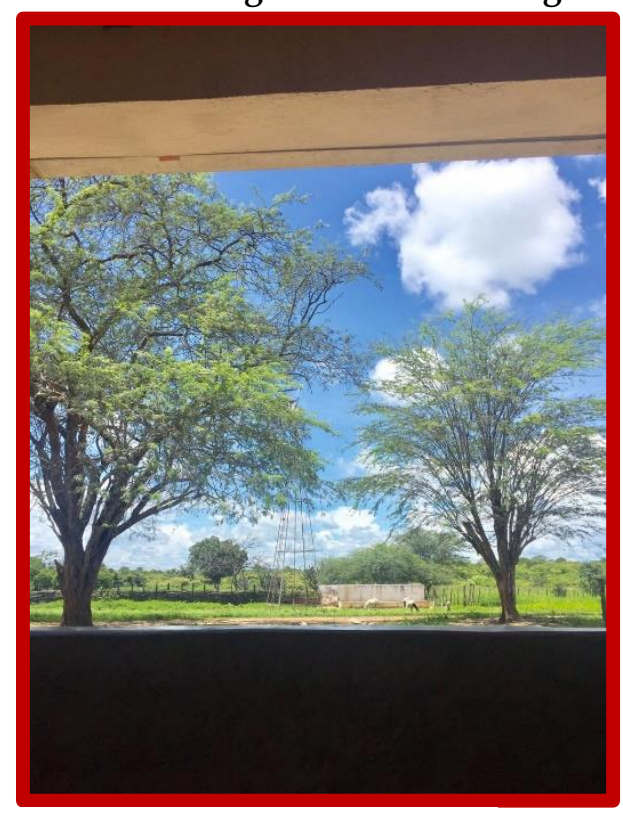

Fonte: Acervo da Família. 


\section{Galeria: OPaisagens}

Foto 33 - Pátio da Cozinha

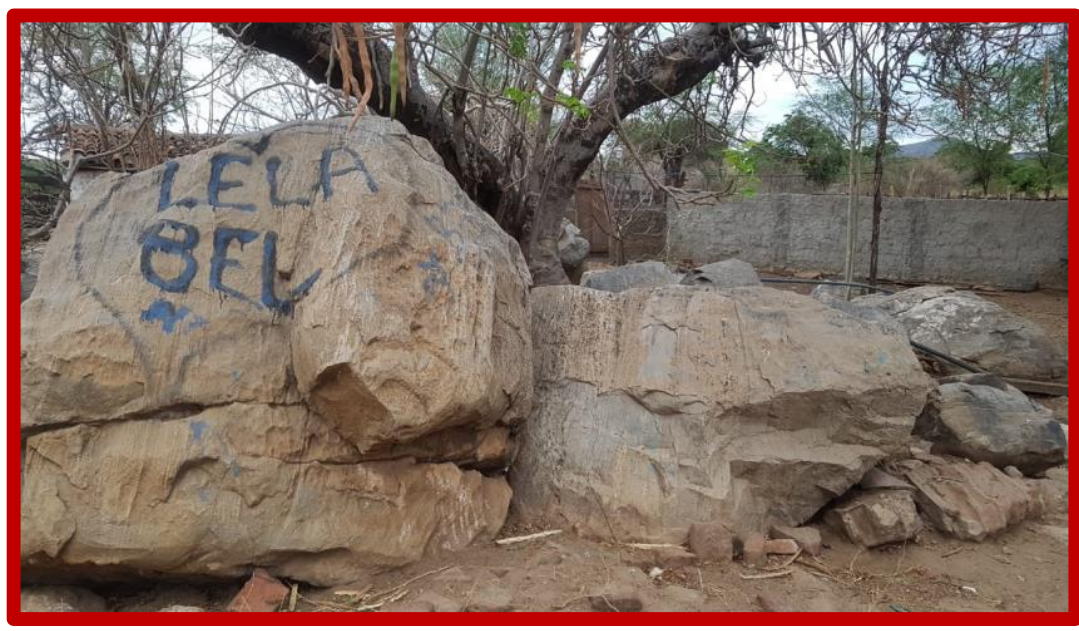

Fonte: Acervo da Família.

Foto 34 - Grutinha Rancho Mucunã de Nossa Senhora Rainha do Sertão

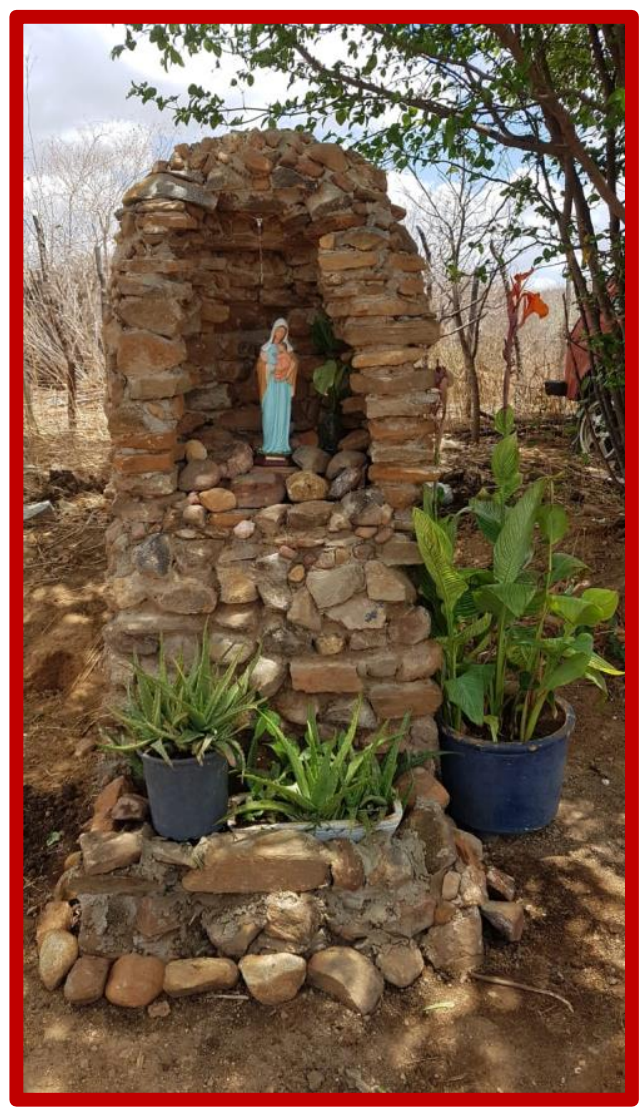

Fonte: Acervo da Família. 


\section{Galeria: OPaisagens}

Foto 35 - Pátio Lateral

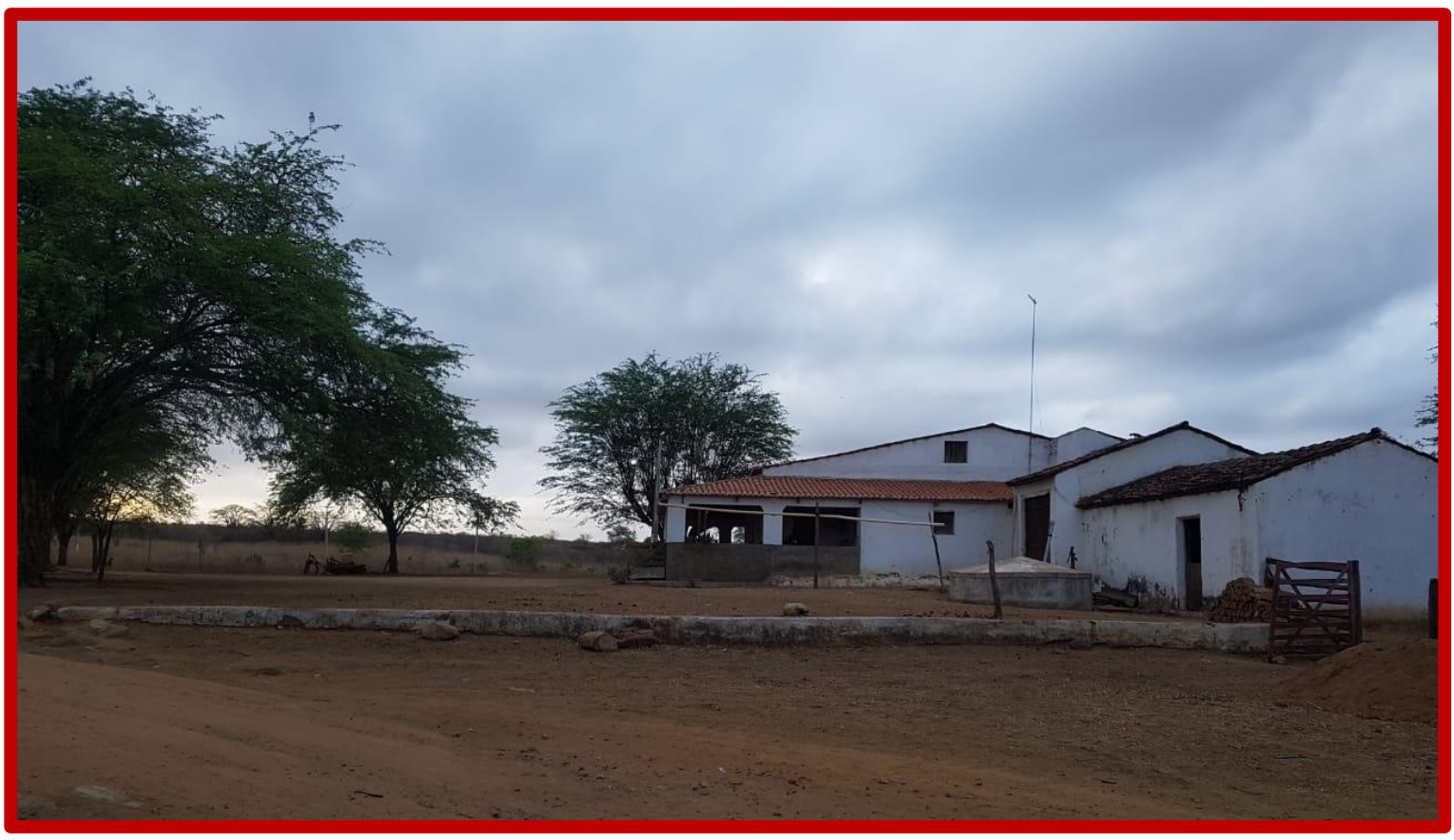

Fonte: Acervo da Família.

Foto 36 - Rancho Mucunã (Família Carvalho Simplício)

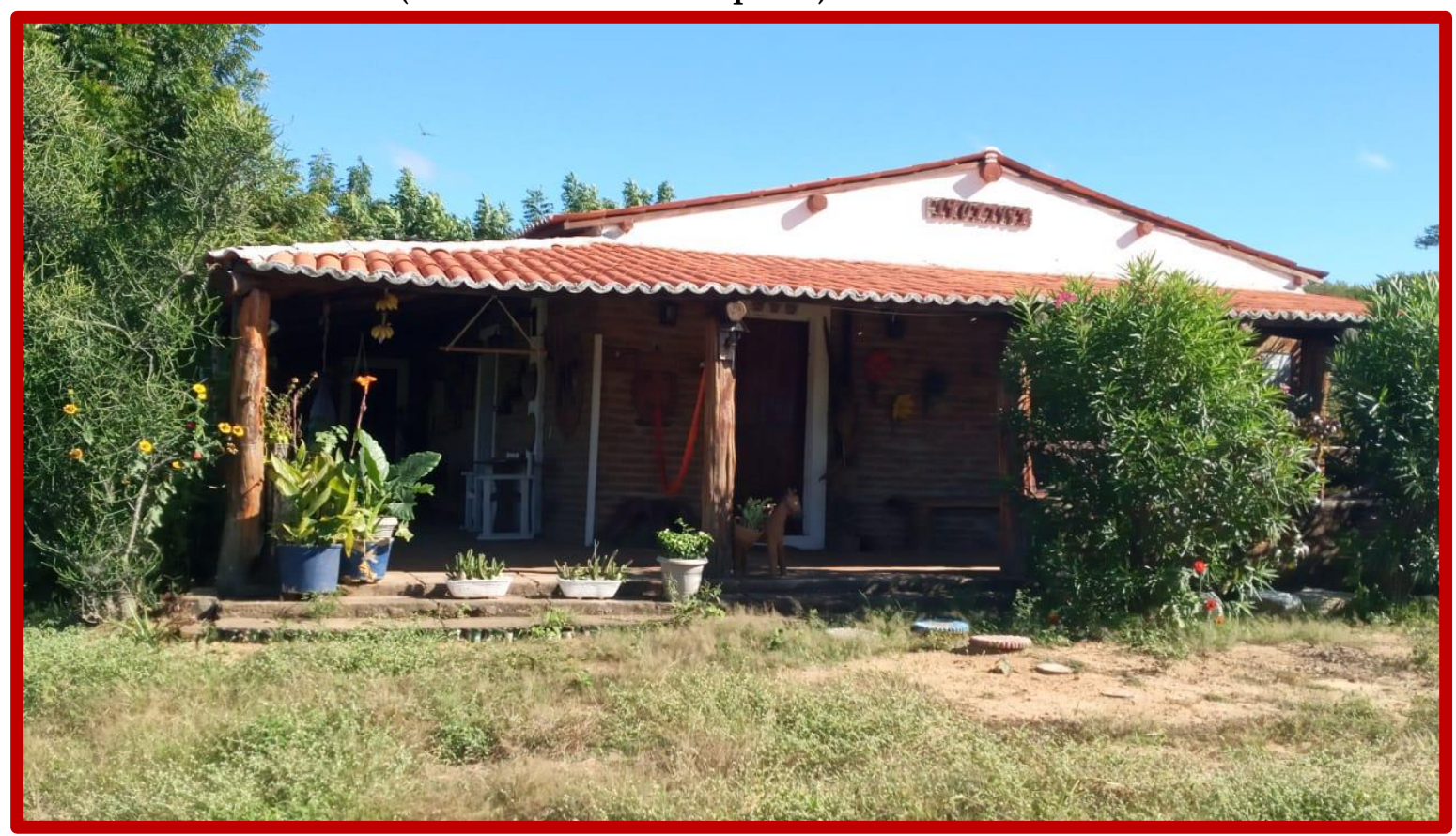

Fonte: Acervo da Família. 


\section{4 @alenia: OPaisagens}

Foto 37 - Vista Lateral do Alpendre

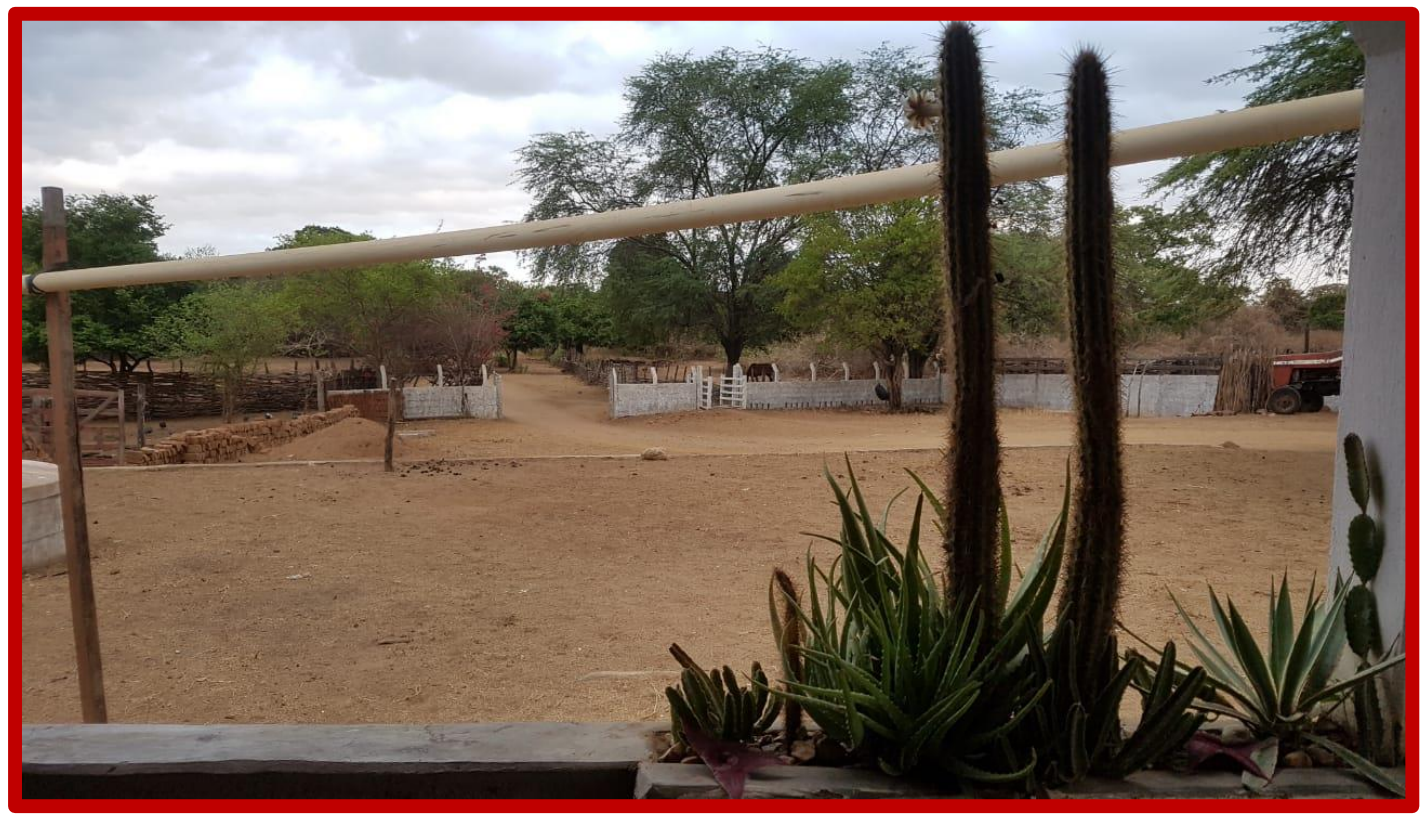

Fonte: Acervo da Família.

Foto 38 - Carnaúba João de Deus (Família Carvalho Machado)

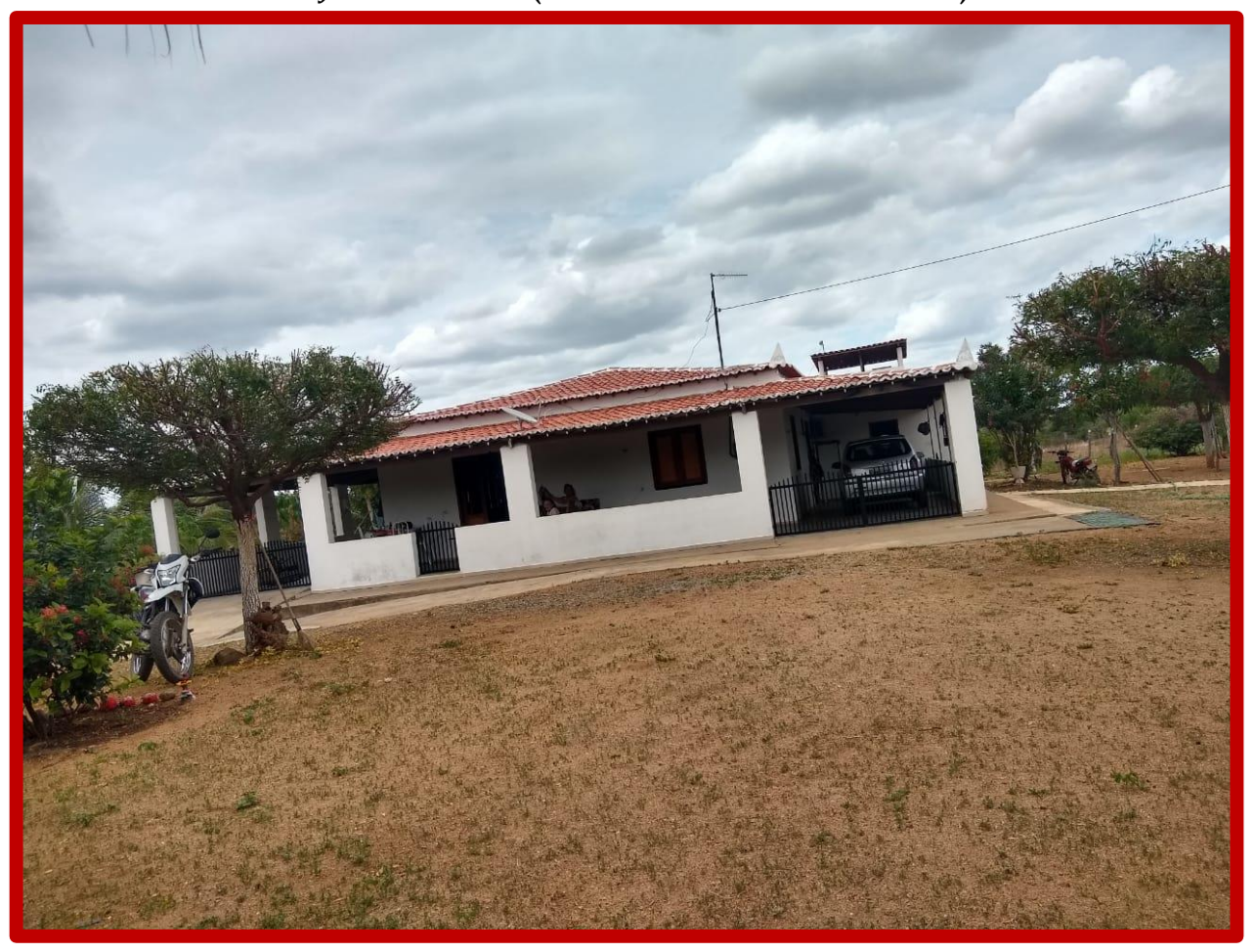

Fonte: Acervo da Família. 


\section{Galexia: OPaisagens}

Foto 39 - Carnaúba Antonino (Família Carvalho Monte)

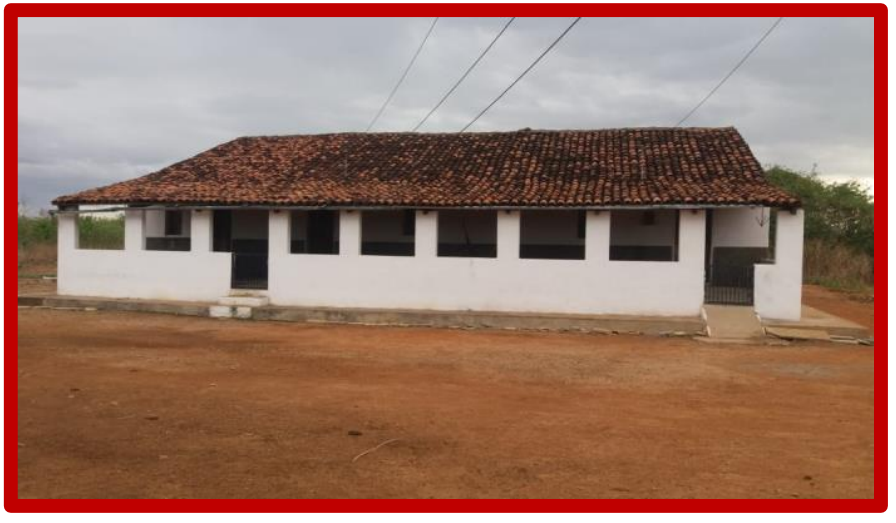

Fonte: Acervo da Família.

Foto 40 - Fachada Antiga da Casa da Fazenda

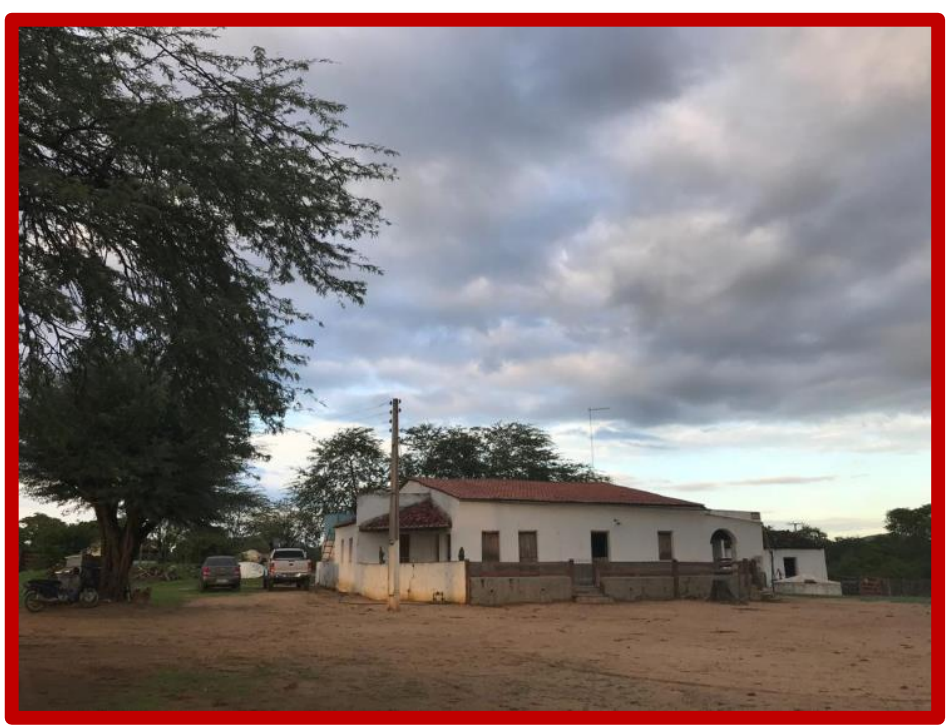

Fonte: Acervo da Família.

Foto 41 - Fachada Atual da Casa da Fazenda

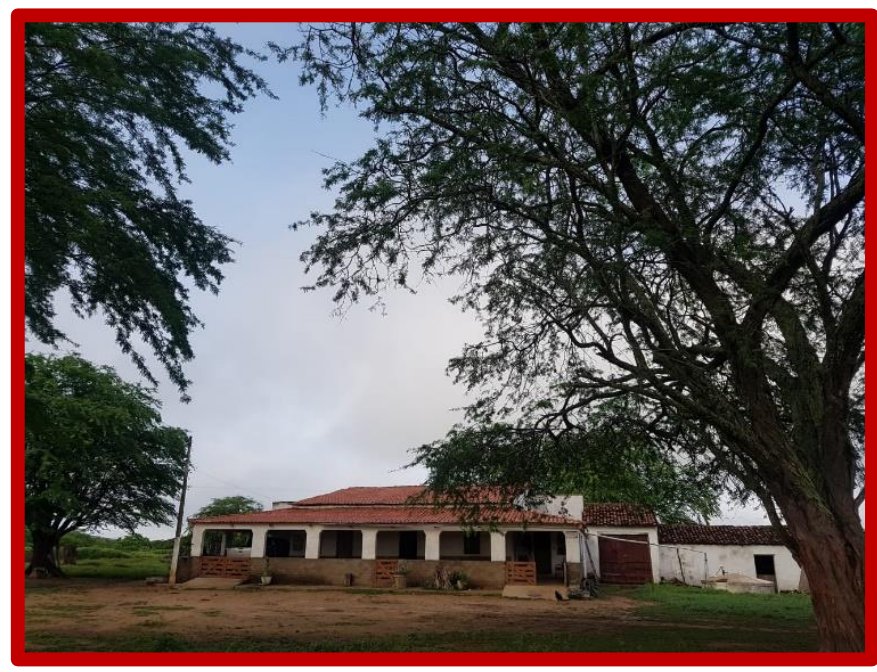

Fonte: Acervo da Família. 


\section{Ossian Oilweira Mtlencax Titho}

Neto, analista de sistemas, trabalha com tecnologia da informação, filho da Danúbia.

\subsection{Alagoano, porém, cearense de alma e coração}

Tive a sorte de passar muitas férias na Lagoa das Pedras, e mesmo sendo uma criança acostumada com energia elétrica e todas as outras facilidades que esta trazia, com dois ou três dias, nem lembrava mais de televisão, ventiladores, desenhos animados, filmes...

Tenho a lembrança do cheiro de querosene que alimentava as lamparinas espalhadas pela casa. Confesso que senti falta das últimas idas à Lagoa das Pedras; das noites na varanda embaladas por um rádio, sintonizado em uma frequência AM, noite adentro, por um dos meus tios; das visitas ao final do dia na casa do tio Virgílio, Branco; das ovelhas e da atenciosa tia Chica, entre tantos... Da rotina da vó Estrelinha, alimentando todas as tardes galinhas e capotes da janela do gabinete do vô Manoelzinho; e do meu chamado característico: "Saaam Filhooo...", este era o chavão que Mãe Zezé me chamava e vovó adotou.

Fui até cabo eleitoral da primeira campanha para prefeito do tio: “É Antônio Luiz ou não é? E arrocha o nó!"

Lembro-me de uma pescaria no açude velho, em que pescamos não mais do que meia dúzia de piabas e, logo mais tarde, no jantar, na primeira garfada, me engasguei com uma espinha que insistia em ficar presa em minha garganta. E, aí, Dona Estrelinha veio com um "remédio" super eficaz para a situação, banana com farinha... problema resolvido!

Não esqueço dos cachorros: Bolinha, Jagunço, do cavalo Retrato... Por fim, alagoano por uma mera questão geográfica e cearense (sertanejo) de alma e a certeza de que minhas raízes estão enterradas com o "velho pé de umbuzeiro".

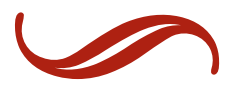




\section{Mariana Gaxwalho@ Seño Gavalcanti}

Neta, enfermeira e professora universitária, casada com Diego Cavalcanti, tem dois filhos.

\subsection{Vida de vaqueiro? Vida de vaqueiro!}

Comecei a ouvir falar das "magias" da Lagoa das Pedras pelas histórias que minha mãe contava quando colocava a gente para dormir. Depois que as conhecemos, sempre eram grandes as expectativas para irmos para a casa da vovó, a Fazenda Lagoa das Pedras.

Eu passava o semestre inteiro contando para meus colegas do Colégio Juvenal de Carvalho como era fantástica a casa da minha avó! Todos ficavam morrendo de vontade de conhecer. Sempre passamos quase todas as férias de julho e dezembro na vovó; eu, Ju, May e Victinho, e sempre voltávamos no último dia, chorando para ficar mais.

Lembro que a vovó nos recebia sempre com muito carinho e atenção, cheiro de bolo com café fresquinho para a nossa chegada. Sua cadeira ao lado do radiozinho e a medalha de Nossa Senhora no peito marcaram muito minha infância. Eu amava sentar no seu colinho fofinho, cheiroso e cheio de amor. Todas as férias, ela me dava um cabritinho que estava no quintal para eu cuidar. Até hoje, lembro o nome do primeiro que ela me deu, era Branca de Neve. Como eu amava dar leitinho para ela!

Eu e meus primos vivemos muitas aventuras na Lagoa das Pedras, muito banho de açude, brincadeiras de casinha no pé de umbu, carregar água na cabeça para encher os potes, tudo se tornava uma diversão, andávamos de jumento e muitas outras brincadeiras.

Julianna e Victor eram os mais danados, inventavam cada aventura que me deixavam com medo. Uma delas que lembro bem era uma que eles nomearam de "Vida de Vaqueiro"; cada um tinha cavalo ou jumentinho, que era o meu caso. Montávamos, cada um no seu, sem sela, e íamos passear. Geralmente, Victor ou 
Julianna guiava o caminho e quando eles gritavam: "Vida de Vaqueiro", eles colocavam os animais para dentro do mato com tudo. Eu era sempre a última da fila, ficava em pânico! Com medo de cair, de me furar nas plantas, mas não tinha como evitar, pois sempre meu jumento acompanhava os outros animais.

Certa vez, eu montei numa jumentinha que estava prenha; eu falava para os meninos: "gente, vamos embora que vai já parir aqui". Eles só faziam rir da minha situação. Julianna feria as pernas "toda" nos galhos das plantas, mas ela achava o máximo chegar no colégio mostrando para as amigas como tinha aproveitado as férias. Papai dizia que ela não se preocupasse, pois quando ela ficasse mocinha, ele mandaria tirar as manchas a laser. Até hoje, ela espera esse laser...

No pé de umbu, brincávamos de casinha; os galhos eram como se fossem nossos quartos. Lembro que o Victor era o pai da casa e montava no seu cavalo para ir trabalhar e trazer os mantimentos para a comida. Uma vez, fizemos até fogo de verdade para fazer comidinha. Um perigo! Vovó não sabia desse movimento.

Eu gostava muito de passar os finais de tarde na casa da tia Ludugera, conversava, tomava café, adorava brincar com os netos dela. Sempre tive esse lado materno.

Recordo de umas férias que a tia Lela estava lá com a Camilinha, bebê; eu passava o dia brincando de boneca, dava comidinha, colocava para dormir e ainda dizia para a tia Lela que ela não precisava chamar ninguém para ajudá-la porque eu ajudaria. Tia Lela confiava totalmente a Milinha aos meus cuidados!

Sempre fui defensora dos animais, quando ia para a fazenda, ficava muito triste quando abatiam os animais. Sempre que estava programado o abate de um animal (boi, porco, carneiro), eu acordava de madrugada e corria para o quarto da vovó, implorando para que não deixasse isso acontecer. Ela sempre muito atenciosa intervia e suspendia o abate naquele dia. Depois, discretamente, eles faziam sem que eu soubesse.

Acordava muito cedinho para ver os vaqueiros tirando o leite das vacas no curral, achava muito legal o encontro das vacas com os bezerros.

Depois que vovó Estrelinha faleceu, minhas idas para a Lagoa foram ficando menores, até pelo fato de virarmos adolescentes e querermos aproveitar mais 
os eventos da cidade, porém, sempre que penso na fazenda, lembro do cantinho, da cadeira e das coisas dela.

Vejo como minha infância foi mágica naquele lugar encantado! Quando meus filhos estiverem um pouco maior, vou levá-los lá para eles terem a oportunidade de viver também um pouco de magia que eu tive o privilégio de viver.

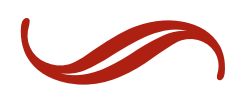




\section{Gamilla Gareatho Pimplicio}

Neta, engenheira de produção e consultora organizacional, filha de Aurélia, noiva de Matheus Sancho.

\subsection{Momentos marcantes}

Nossa, por onde começar? São tantas lembranças boas! Quando lembro da Lagoa, sinto cheirinho de infância, aquele cheirinho de mato molhado (ou de estrume - risos!), sabe?

Foram muitos momentos marcantes que vivi em nossas viagens para a Lagoa das Pedras da vovó Estrelinha e do vovô Manoelzinho, começando pela forma como íamos, que era uma verdadeira aventura! Lembro bem de algumas idas na F1000 do papai. Eu e meu irmão íamos na carroceria, deitados em um colchão, com uma lona a postos para o momento de passagem pela Polícia Rodoviária, onde éramos orientados a nos abaixar. Já pensou? Meu Deus! Mas dava tudo certo, e nós amávamos o jeito "raiz", e um tanto irresponsável, eu sei, de viajar.

Nossas férias sempre coincidiam com o início do inverno (janeiro) ou com o fim (julho), quando ainda estava tudo verdinho. Geralmente quando chegávamos lá, já estavam nossos primos que também só víamos nesses períodos, mas que ainda assim eram e são até hoje, grandes amigos, além dos laços sanguíneos. Lembro principalmente dos que tinham a minha faixa etária: Mirlla, Laryssa, Hortêncya e Davi, estes dois últimos menores, na faixa etária do meu irmão, Matheus.

Outra coisa marcante era quando chegávamos e o rio estava cheio, por sinal, a gente rezava e torcia para encontrar o rio cheio, pois era aventura garantida. Passar o rio com água pela cintura, com as coisas na cabeça, vendo todo mundo aguardando e dando instruções para a passagem do outro lado era demais! Melhor que qualquer parque de diversões. Quando eu voltava às aulas e contava para minhas amigas ninguém acreditava. 
Esse mesmo rio tem árvores fáceis de subir nas margens, ali perto da passagem da estrada de piçarra mesmo. A gente subia em uma dessas árvores e algumas vezes ficávamos sem coragem para pular, o que nos encorajava eram os velhos camaleões que apareciam nos galhos, coisa bem comum. Aí menino, o medo acabava bem "ligerim" (ligeiro)! O salto dava um frio na barriga, e a queda desconcertada na água às vezes era bem dolorosa, mas ao mesmo tempo divertidíssima.

O rio já era bem fundo, mas tio Antônio Luiz ainda mandou afundar mais, cavando, pois passando o inverno, o gado ficava tomando água de lá, pelo que me lembro. O objetivo do salto passou a ser conseguir encostar os pés no fundo.

Quando chovia, brincávamos na chuva, correndo de um lado para o outro no terreiro da casa, do cata-vento ao pé de umbu, e pelo caminho da casa do tio Virgílio. O melhor era brincar na lama que se formava. Tem até uma foto nossa, todos sujos de lama, só com os olhos de fora.

Eu, Mirlla, Laryssa e Hortêncya brincávamos de casinha no pé de umbu. Como parte das raízes do umbuzeiro sobressai a terra, as usávamos para separar os cômodos da casa. Entre uma raiz e outra tínhamos sala, quartos e cozinha, tudo muito limpo, varrido mil vezes com vassoura de palha. Os móveis imaginários eram todos feitos de pedras, ficava uma lindeza. Fazíamos todas as tarefas de uma casa, como varrer, organizar, pegar água, e a melhor parte: fazer a comida! Montávamos nosso fogãozinho a lenha com pedras e gravetos, e tínhamos o desafio de acender.

Uma vez, Mirlla, sempre muito resolvida, foi até a casa da Lagoa e pegou "escondido" um pau de lenha já aceso do fogão a lenha e saiu correndo para que ninguém a visse. Missão impossível! Como nenhuma das mulheres que trabalhava na cozinha não veria? Dito e feito, quanto mais as mulheres gritavam para ela não correr, mais ela corria, parecia uma tocha olímpica. Finalmente, depois de muita adrenalina, fizemos o almoço que se resumia em arroz, que apesar de muito duro e com cheiro de fumaça, a gente comia para fazer valer a brincadeira.

Outros momentos muito legais eram quando íamos andar a cavalo. Uma vez, fomos para as Lajes, um lugar lindo, cheio de pedras e olhos d'água, e no meio do caminho, tinha um campo de futebol com trave grande e tudo. Mayara e Victor se 
garantiam na cavalgada, faziam hipismo e tiveram a brilhante ideia de brincar de "fazer gol" galopando com o cavalo. A gente tinha que passar com o cavalo no galope por baixo da trave, como se fosse mesmo um gol. Em uma dessas passagens, Victor na sela e eu na garupa, o cavalo tropeçou no buraco do ninho de um passarinho que prepara seu ninho no chão (eu nem sabia que isso existia, mas existe sim, não sei se o nome do pássaro é Tetéu, mas esse era um nome bem falado), quase que caí, mas Victor, por sorte, pensou rápido e me segurou. Depois morremos de rir!

Um momento extremamente marcante foi a chegada de energia elétrica na fazenda. Lembro-me perfeitamente, e na realidade me deu uma pequena frustação, pois parecia outro lugar, sem as lamparinas e com televisão, mas logo nos acostumamos, pois havia muitas outras possibilidades de brincadeiras, e nada tira o encanto daquele lugar.

Na varanda, que na verdade é um grande quarto com muitos armadores, adorávamos estar todos os primos reunidos, naquele clima de férias na casa da avó, balançando nas redes, mesmo com muitas advertências dos nossos tios. O grande objetivo era ficar no casulo da rede e balançar até dar uma volta no ar, ou seja, ficar de cabeça para baixo, como se fosse uma montanha-russa. No auge da brincadeira, gritos e gargalhadas, Tio Helder entra na varanda em uma tentativa de acalmar os ânimos, cantando: “Deus é bom pra mim, Deus é bom pra mim”, primeiro com palavras, depois em assobio, em sussurro, e, por fim, apenas com gestos, até conseguir o silêncio. Ele conseguiu, foi demais!

Teve uma viagem que nunca esquecerei. Quando fomos todos, todos, ou quase todos, mas foi muita gente, para a posse do Tio Antonio Luiz como prefeito de Quiterianópolis. Alugaram van, levaram saco de dormir e deixamos a casa pequena para tanto amor reunido.

Em um dos trajetos nessa van, não lembro se indo da Lagoa para a sede de Quiterianópolis, Kaká (filho da tia Danúbia) dirigia e viu na estrada um carro parado, passou pelo carro e depois foi dar marcha à ré para ajudar (eu dormia nessa hora no colo de alguém, me contaram essa parte. Eu tinha uns 8 anos.). Nessa marcha à ré a van caiu em um buraco na margem da estrada, ficou perto de descer a ribanceira. Lembro-me acordando sem entender nada, e as pessoas saindo devagarzinho da van 
com medo. Não foi muito legal, mas foi muito marcante. Carros foram nos buscar e no outro dia um trator foi puxar a van.

Percebi, então, que tinha crescido quando de repente, em uma dessas viagens, não sei dizer quando exatamente, cheguei à Lagoa e achei a mesa da sala, que quando criança achava gigantesca, bem pequena, e vi que a varanda realmente não passava de um quarto! Foi um sentimento estranho, me lembro como se fosse hoje.

Vivi inúmeros momentos marcantes em nossa Lagoa das Pedras e, com certeza, ainda viverei, agora também no Rancho Mucunã 


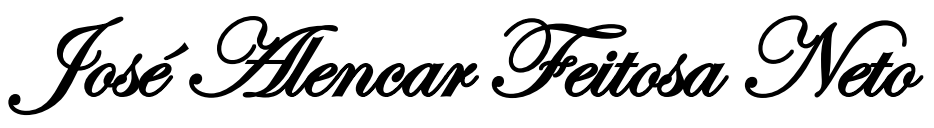

Neto, advogado e empresário, filho de Danúbia, casado com Ítala, tem uma filha.

\subsection{Vovô Manoelzinho (nossas rondas)}

Tenho a impressão de que ainda me lembro um pouco do cheiro do vovô Manoelzinho. Acredito que especialmente por ter tido o privilégio de, ainda bem menino, poder estar bem próximo dele, ao acompanhá-lo na garupa do Retrato, em algumas de suas rondas pela nossa querida Lagoa das Pedras.

Como era bacana! Nunca me esqueci daqueles momentos. Só nós três. Sim, incluo aqui na conta aquele saudoso cavalo branco ou azul molhado, manso e de marcha, até hoje, incomparável. O cavalo do Seu Manoelzinho! Com todo cuidado, vovô me trazia na garupa, orientando para segurar firme em cada correia. Saíamos naquela marcha suave.

Admirado, eu olhava para cima, vendo suas longas costas em camisa comprida, chapéu na cabeça e chicote pendurado no punho, deitado sobre sua coxa. Enquanto eu olhava o que podia, vez por outra, escutava um pigarro. E, assim, seguíamos.

Aqui e acolá, ele se certificava da firmeza de um mourão. Nisso tudo, sempre atento, desviando do pequeno passageiro qualquer coisa, especialmente, os galhos de jurema. Como achava interessante e me sentia seguro ali com ele. Até hoje, se me vejo tentando livrar alguém de algo, me lembro das juremas do vovô. Lições para toda vida. Saudades das nossas rondas. 


\subsection{Vovó Estrelinha (comer, rezar e amar)}

“Vovó Estrelinha”. Não consigo imaginar por aí formas mais carinhosas e apropriadas para se referir a uma amada vozinha. E, neste caso, o privilégio foi nosso. Vovó era todo cuidado conosco e com todos.

Já na chegada para as férias, após a acolhida, sua primeira missão era não escapar um piolho sequer na cabeça de cada netinho. Pois é, piolho alagoano não tinha vez por lá não. Daí para a frente, continuava sempre com seus mimos. Tudo fazia, tudo organizava.

Verdadeira matriarca, generosa com todos, sempre devota com seu terço do final das tardes. Devo a esta muito de minha devoção cristã. Até hoje, me recordo de antigas canções que aprendi com ela. “A nós descei divina luz (bis), dás nós a benção, ó Virgem Mãe, penhor seguro do sumo bem (bis)", entre outras.

“Oh! Edmilson!” Lá estava ela na varanda; desta vez, chamando nosso amigo, companheiro de brincadeira. Que tempos bons, vovó, muito obrigado!

\subsection{Malu na Lagoa}

Desde bem criança, passei todas as fases da minha vida sempre ligado à Lagoa das Pedras. Algumas épocas mais presentes, outras nem tanto. E agradeço a Deus por todos esses privilégios e, especialmente, pelo último acontecimento.

Eu e minha esposa Ítala, depois que decidimos pela paternidade, passamos a trilhar uma longa caminhada, na tentativa pela tão sonhada gravidez. Após várias tentativas, chegamos a viajar a São Paulo, em setembro de 2018, para tentar uma FIV por fertilização in vitro. Depois de todo o processo, voltamos para casa sem sucesso, tendo acumulado grande tristeza e desgaste físico-emocional. Confesso que aquilo nos abateu com força, pois em virtude da adiantada idade do casal, nossas chances nos pareciam ter minguado.

Nossa família cearense estava organizando um grande Réveillon com todos na praia do Cumbuco. Achei que viajar para a festa e de lá para a Lagoa das Pedras nos ajudaria a amenizar aquela fase que passávamos. Um detalhe: na véspera da 
viagem, me peguei pesquisando sobre planejamento futuro e qualidade de vida para casais idosos sem filhos. Foi carregando esse sentimento que partimos para a viagem.

Depois de uma ótima virada de ano, seguimos para a nossa Lagoa das Pedras. Era a primeira vez que minha amada esposa conhecia nosso berço, uma experiência que ela gostou desde o começo.

Certo dia, calculei e percebi que ela já estava há 37 dias sem entrar em ciclo. Resolvi pegar a estrada em direção a Novo Oriente para comprar mais um de tantos testes de gravidez. Por volta das 13 horas, retornei, lhe entregando o teste para ser feito na manhã seguinte. Não demorou, ela passou e me chamou insistentemente. Acreditando ser para almoçar, fui ao seu encontro. Para minha surpresa, apareceram na minha frente aquelas tão esperadas duas listrinhas, das quais nunca mais esqueceremos. Era ali, nossa Maluzinha, dando o seu primeiro gritinho de que em breve estaria conosco. Em meio a emoção contida do casal, fomos para nosso quarto, quarto do tio Carvalho e Silvania, generosamente cedido. Oh! Meu Deus! Quanta graça e alegria! Não poderia ser diferente, aquela dádiva transbordou minha esposa em choro de emoção. Foi quando tia Dalvinha nos encontrou ali e soube que seria mais uma vez titia. Não demorou muito e, por um instante, todas as tias, primas e senhoras já se acumulavam em oração em frente ao santuário do quarto da vovó Estrelinha, local no qual ficaram aquelas listrinhas. Foi inesquecível! Pouco tempo depois, fomos fazer o beta no laboratório do nosso primo, Dr. Victor. Positivo!!!

A vida nos ensina sempre. Estávamos no maior centro do país, buscando fazer tudo da nossa forma, mas foi no longínquo sertão do Ceará que soubemos da maior alegria das nossas vidas. Como sempre, no final, Deus tudo providencia e faz por seus filhos. Este é nosso testemunho de como Ele sempre foi generoso conosco! Como me disse a tia Aninha, a notícia da vinda da Malu, na Lagoa das Pedras, teve todo um simbolismo. Pessoalmente, concordo plenamente. 


\subsection{Varanda, conversa sob a luz de lamparinas}

Uma das coisas que mais gostava na fazenda era ficar escutando histórias, conversas interessantes na calçada todas as noites, sob a luz das lamparinas e daquele lindo luar do sertão. Moradores não faltavam, muito menos boas histórias e "causos". Como aquilo era interessante para um menino da capital! As vozes, na maioria das vezes, vinham do escuro, sem atropelo, sem moderador. Cada um atento e respeitando a prosa dos demais. Verdadeira mansidão, misturada com tranquilidade e concentração. Era com esta "chave de ouro" que fechávamos nossos dias de diversão.

\subsection{Cutia Mamante}

A terrível "Cutia Mamante"! Não havia quem não pulasse da rede ao primeiro sinal. A aproximação dessa ameaçava logo bem cedinho. Não sei se todos conhecem. Se for o caso, alguém peça ao tio Toinho para lhes apresentar esse bichinho típico da Lagoa das Pedras. Jamais esqueceram, sem falar que se tornaram exímios saltadores de redes.

\subsection{Tio caçador}

Se algum dia fui caçador, foi lá pelas bandas da Lagoa das Pedras. Pois lá não nos faltaram inspirações, principalmente vindas do tio caçula, que muito nos admirava com suas habilidades e jeito para negócios. Sem falar das inúmeras histórias contadas. Algumas vezes, tive o privilégio de acompanhá-lo, seguindo sempre a certa distância, tentando não atrapalhar. Que orgulho de estar ali testemunhando aquela arte para ele! Tão natural! 


\subsection{Careta do boi brabo}

Quando pequenos, sempre temos a impressão de termos um tio ou parente mais “zangadão". Para mim, este era o tio João. Nunca esqueço do dia em que, por volta dos 10 a 11 anos, o acompanhei a cavalo, quando ele saía de gibão e perneira para ir buscar uma vaca perdida lá para o lado das Lajes. Circulamos, circulamos, até que vimos de ré. Daí, saíram eles em toda disparada, entre gritos, trotes e quebra de galhos. Não demorou quase nada e eu já os havia perdido. E “o pau comendo"... Eu perdido.

Depois de alguns poucos minutos, passou a reinar aquele silêncio, quando de repente... no meio da mata, aqueles trovões... era o vaqueiro gritando por meu nome. Quando finalmente o encontrei, lá estava ele terminando de botar a careta no boi bravo, já no chão dominado. Fiquei impressionado, mas também decepcionado, por não ter acompanhado, sentimento este logo extirpado, quando do meio daquela pressão, por ele fui elogiado.

Com o passar dos anos, fui percebendo que por trás daquele jeito durão, se escondia um grande coração. Eu ficava até invocado quando ele nos pedia para coçar as costas dele. Pois não é que coçávamos! E, assim, foi caindo para mim aquela careta de tio bravo.

\subsection{Pingo}

Quando criança, tive como primeiro livro, a "estória" de um potrinho que tinha como grande desafio saltar um riacho da fazenda. De cor branca, com pingos pretos, seu nome e o título do livro foram a minha inspiração para dar nome ao cavalinho que o vovô Manoelzinho me deu.

Não muito diferente do potrinho, o Pingo da Lagoa das Pedras não era muito grande, mas, na minha cabeça, era igualmente valente e rápido. Ele conviveu por muitos anos conosco. Imaginem o orgulho que eu tinha daquele companheiro, e como esta história foi importante para mim. Coisas da Lagoa das Pedras!!! 


\subsection{McDonald's da serra}

Passávamos nossas férias do meio e final de ano, integralmente na fazenda, principalmente os meninos maiores: eu, Carvalinho e Mourãozinho e, mais tarde, Sam e Henrique. Numa dessas férias, eu e Carvalinho acompanhamos os vaqueiros na retirada do gado da Lagoa das Pedras para a serra (São Jerônimo e Guaribas).

Fomos bem a caráter, inclusive de gibão e perneiras. O Carvalinho seguia à frente do gado, carregando os alforjes com a comida para a viagem. Há quem diga que ele se apressou com lanches, não sobrando nada para a turma. Depois de longa jornada, já na Serra, acomodados no local, no qual os dois irmãos teriam que dividir a rede.

Ao aproximar da hora da "boia noturna", Carvalinho consultou os tios se poderia comer um McDonald's no jantar. Até hoje, a "gaitada come" (risada à vontade), quando se conta esse fato. Vai ver que a franquia teria feito sucesso por aquelas bandas de lá!

\subsection{Besouro de porre}

Normalmente, todo rapazinho tem seu primeiro porre. O meu foi no Besouro, aos 14 anos. A história foi longa, assim como a ressaca... Começou às 18 horas, na Lagoa das Pedras, mais precisamente no bar do Francismar. Eu, tentando acompanhar o tio Carvalho e o Vieirinha no conhaque Dreher. Isto não iria dar certo! De lá, partimos de moto para o Besouro, para a agitada noite de baile. Ainda no bar da "cidade", perdi as contas das doses, e no baile já não sabia quantas cervejas já tinha tomado. Se não fosse o forró, acho que não chegaria ao raiar do sol.

Lá pelas 7 horas da manhã, a turma dos Carvalhos/Coutinhos/Vieiras voltou para o bar da cidade para continuar com os trabalhos. Só me lembro até meiodia. Daí para frente me colocaram numa rede do bar. 
Lá pelas 17 horas, o "Uber" chegou. Tio Toinho veio me buscar. Pior que veio de moto. Foi difícil chegar a casa, mas chegamos. Primeiro, fiquei de molho por um tempo no Rio Poti e, depois, só me restou rede e ressaca. Sobrevivi, mas jurei na manhã seguinte nunca mais tomar um gole de cerveja.

O tempo cura tudo. Como dizem, nunca se esquece do primeiro porre, ainda bem que o meu foi lá pelas bandas da Lagoa das Pedras. 


\section{Guilherme MSatheus Gaxualho Oimplicio}

Neto, advogado, filho de Aurélia, solteiro.

\subsection{Histórias da Fazenda Lagoa das Pedras}

Acredito que a Fazenda Lagoa das Pedras sempre foi o refúgio de todos da Família Carvalho e dos seus amigos. A simplicidade do sertão, o aconchego da família e o carinho dos seus moradores presenteiam seus frequentadores com experiências inesquecíveis.

Devido a tais características, certamente, a Fazenda Lagoa das Pedras proporciona felicidades para quem chega e saudades para quem parte.

As férias da minha infância e da minha adolescência eram sinônimo de "ir para a Lagoa das Pedras". Impossível seria passar um ano inteiro sem que eu passasse, pelo menos, dois meses nesse lugar, berço da minha família.

Ao aproximar dos períodos de ir para a Lagoa, o frio na barriga crescia com a ansiedade de chegar para ver meus tios e meus primos, para poder brincar no terreiro da Casa Grande, nos açudes da propriedade e nas estradinhas dos lugarejos, sempre sentindo o cheiro de mato verde ou a poeira dos verões intensos.

Ainda hoje, quando posso ir visitar a Lagoa, as mesmas emoções voltam à tona. E é por isso e por outras coisas que histórias nesse lugar não faltam.

Para partilhar um pouco das minhas diversas experiências lá, escolhi contar duas histórias que envolvem bicicleta e moto, duas paixões que aprendi e desenvolvi na Lagoa. 


\subsection{A caminho da Festa de Reisados (de bicicleta)}

Aprendi a andar de bicicleta sem rodinha muito novo, no terreiro da Casa Grande. Desde então, a minha maior diversão era sair pedalando pelas estradas afora da fazenda. Tanto é que, até hoje, as pessoas que me conhecem de perto, quando me veem, normalmente, me fazem a pergunta: "Como vão as pedaladas?!"

Pois bem. Era o mês de julho. Eu tinha de 11 para 12 anos. De criança, só tinha eu na fazenda, com a presença do tio Antônio Luiz em casa. O meio de transporte popular da região ainda era cavalo ou bicicleta. Como eu nunca tive bom jeito para andar a cavalo (embora admirasse bastante), usava a bicicleta para ir para todo canto.

Nessa época, um mercadinho do Monteiro (Distrito de Quiterianópolis/CE, onde fica a Fazenda) estava começando a crescer e a trazer novidades de fora para a localidade. E uma das novidades que ele estava vendendo era um farol para bicicleta movida a dínamo - um "motorzinho" conectado ao pneu da bike, que dava energia (e ligava) a lâmpada quando o ciclista pedalava. Achei o máximo. Usei quase todo meu dinheirinho de passar o mês inteiro de férias nesse farol para a bicicleta.

Pronto! Estava com minha bicicleta equipada com um super farol movido a dínamo e eu, morto de satisfeito. Só que tinha um problema: só dava para aproveitar a funcionalidade da nova aquisição à noite, e eu não encontrava um cristão, sequer, que quisesse andar de bicicleta comigo no breu dos matos, sem um destino certo.

Até que descobri, pelo Edmilson, que estava tendo uma “Festa de Santos Reis" no Canto - uma das localidades da Lagoa das Pedras. Não sabia nem o que era essa festa, mas sabia que era uma boa oportunidade para inaugurar o farol da bicicleta.

Pedi permissão do tio Antônio Luiz para ir para essa festa com o Edmilson. Permissão concedida!

Assim, fomos eu e Edmilson no escuro, de bicicleta, para a localidade Canto. Atrás, ia eu para iluminar o caminho à frente e, na dianteira, o Edmilson, com algumas doses de cana na cabeça, conduzindo sua Monark Barra Circular, sem freio. Isso na estradinha super acidentada que vai da Casa Grande para o Canto.

Devido ao farol ser movido a dínamo, quando a bicicleta diminuía a velocidade, a intensidade da luz ia diminuindo até apagar. 
Na primeira descida com um grande buraco no final, fui parando a bicicleta para passar devagar pelo obstáculo, e a luz foi apagando. Nesse ritmo, o Edmilson, que já estava na iminência de cair no buraco, gritou: “Aumenta essa luz, menino!”

Edmilson não entendia o mecanismo do farol e achava que eu apagava a luz de propósito, quando ele estava perto de atravessar o buraco.

Em resposta, eu só fazia rir, porque não tinha o que fazer.

Assim, caímos os dois.

Resultado: mais para frente foram mais umas duas quedas até chegar ao Canto.

Ao chegarmos, estando os dois sujos de barro, deparei-me com uma festa popular muito bonita, onde os nossos moradores se apresentavam fantasiados com roupas folclóricas muito interessantes, praticando rituais da tradicional Festa de Reisados.

Foi uma noite cômica e memorável.

Voltamos por volta das 2 horas pela CE-187. Dessa vez, sem quedas.

\subsection{A Autoescola do Teté}

Eu já tinha por volta de uns treze anos. A motocicleta se popularizava no sertão e nas estradinhas. Já não se sentia tanto o cheiro típico de cavalos, jumentos e burros. O barulho de motores e o cheiro de gasolina queimada tomavam conta do cenário.

Ao ir para a Lagoa, minha maior vontade passou a ser aprender a andar de moto.

Na Casa Grande, tinha a Honda Bros do tio João, a melhor e a mais bem cuidada, e tinha a Bros da Fazenda, utilizada para trabalho.

Eu queria aprender, mas não tinha coragem de usar a super moto do tio João - com medo de uma queda e de um consequente grande carão - e quase não tinha acesso à moto da fazenda, que não parava em casa. 
Nesse contexto, o famoso Teté ("vota quem quer"), morador caricato e cômico por natureza da região, com sua esperteza, deu logo a solução: iria emprestar a moto dele para eu andar à vontade.

Tratava-se de uma Honda CG 125 do final da década de 1980 ou do início dos anos 1990. Era mais velha do que eu.

Ocorre que, para eu usar a moto dele, eu tinha que a consertar quase toda, pois ela vivia sofrendo com as quedas do dono, que vivia cheio de cachaça na cabeça. Assim, meu dinheirinho das férias ia quase todo embora nessa moto.

Mas, de fato, era um bom negócio para os dois: o Teté tinha sua moto consertada toda vez que eu ia para a Lagoa, e eu matava meu "verme" de andar na moto velha.

Uma dessas vezes, encontrei a moto dele jogada no canto da estrada. Não estava dando nem partida. Peguei-a, fui empurrando e, mais à frente, encontrei-o a pé e falei:

- Teté, encontrei tua moto jogada na estrada. Tu não quer mais não, é?!

E ele respondeu:

- “Eu quero uma moto é para ela me carregar, não para eu ficar carregando ela."

Percebi que a moto estava quase sem combustível e disse a ele que ia abastecer e ajeitar (doido para matar o verme). O cômico foi ele me ensinando a abastecer: simplesmente, tinha que sacar o tanque fora da moto para colocar a gasolina para depois instalá-lo de volta. O risco de incêndio era enorme.

Dentre essas idas e vindas à Lagoa, acrescentei a minha $\mathrm{CNH}$ a categoria $\mathrm{B}$. Tudo graças à autoescola do Teté. 


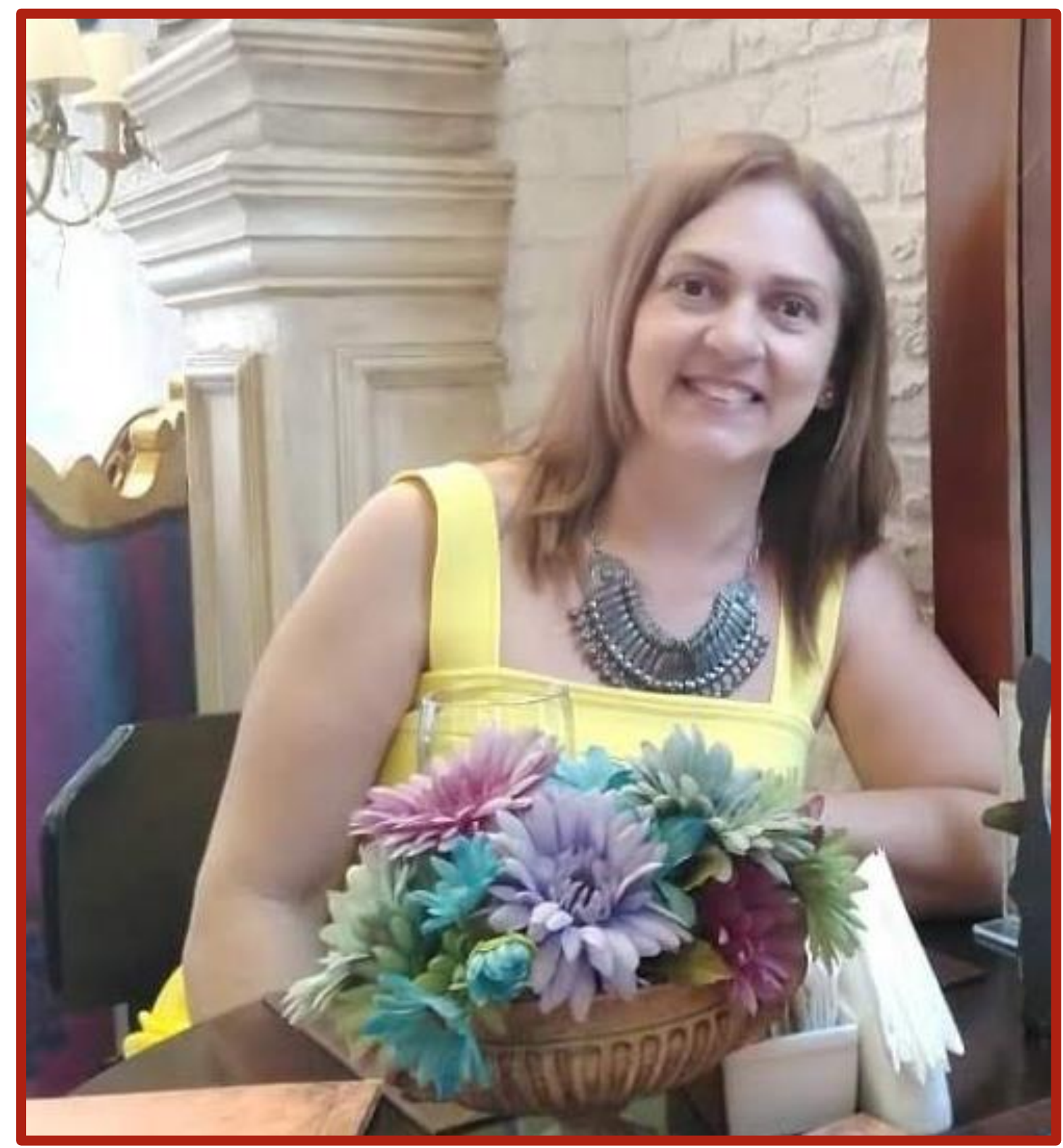

\section{M autora \\ Aruxelia Estela Goutinho Gasualho Oimplicia}

Aurélia Estela Coutinho Carvalho Simplício, advogada, casada e mãe de dois filhos:

Camilla e Guilherme Matheus. É apaixonada pela vida e seu maior hobby é a decoração. As diversões que mais aprecia são encontrar a família, viajar para o sertão, aproveitar a fazenda e o Rancho Mucunã. Descobriu o dom de escrever por acaso e, produziu o livro "Contos da Lagoa", que retrata as histórias do passado e do presente da Fazenda Lagoa das Pedras, berço da Família Carvalho. Seu conselho de vida é: “Não entregue sua felicidade nas mãos de ninguém." 
0 livro Contos da Lagoa tem por objetivo registrar histórias, contos, relatos, fatos acontecidos e vivenciados pela Família Carvalho, moradores e amigos da Fazenda Lagoa das Pedras, município de Quiterianópolis-CE, ficando, desta forma, registradas e perpetuadas as histórias da Família, oportunizando, assim, que as gerações vindouras conheçam um pouco mais sobre as suas raízes. Este livro possibilitará que a Fazenda Lagoa das Pedras, de propriedade da Família Carvalho, tão desfrutada e amada por todos, fique eternizada.

\section{Aurélia Estela Coutinho Carvalho Simplício}

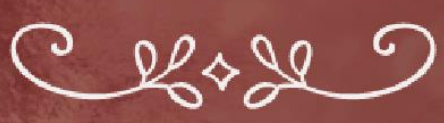

